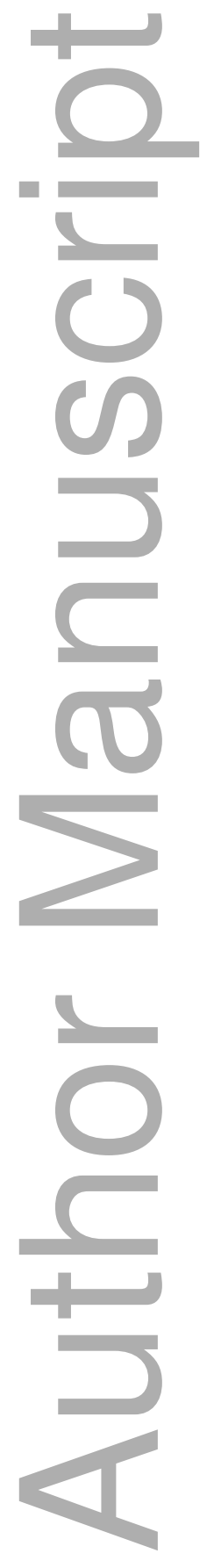

This is the author manuscript accepted for publication and has undergone full peer review but has not been through the copyediting, typesetting, pagination and proofreading process, which may lead to differences between this version and the Version of Record. Please cite this article as doi: 10.1111/jmg.12211

This article is protected by copyright. All rights reserved 


\section{Activity-composition relations for the calculation of 2 partial melting equilibria in metabasic rocks.}

${ }_{3}$ E. C. R. Green ${ }^{1 *}$, R. W. White ${ }^{2}$, J. F. A. Diener ${ }^{3}$, R. Powell ${ }^{4}$, ${ }_{4}$ T. J. B. Holland ${ }^{5}$ and R. M. Palin ${ }^{2}$

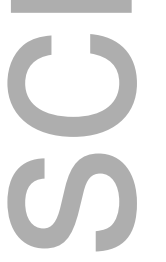

${ }^{1}$ Institute of Geochemistry and Petrology, ETH Zurich, Clausiusstrasse 25, 8092 Zurich,

$6 \quad$ Switzerland(eleanor.green@erdw.ethz.ch)

$7{ }^{2}$ Institute of Geosciences, Johannes Gutenberg University of Mainz, 55128 Mainz, Germany

${ }^{3}$ Department of Geological Sciences, University of Cape Town, Rondebosch 7r01, South

9 Africa

${ }_{10}^{4}$ School of Earth Sciences, University of Melbourne, Victoria 3010, Australia

${ }_{11}^{5}$ Department of Earth Sciences, University of Cambridge, Cambridge, CB2 3EQ, UK

$12 *$ Corresponding author

13 Short title: $A-x$ relations for metabasic rocks

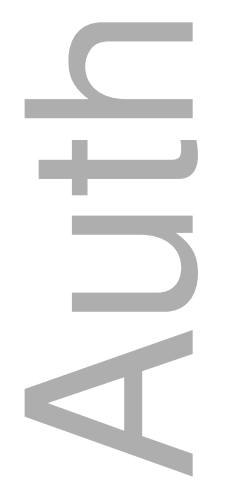

This article is protected by copyright. All rights reserved 
A set of thermodynamic models is presented that, for the first time, allows partial melting equilibria to-be calculated for metabasic rocks. The models consist of new activity-composition relations combined with end-member thermodynamic properties from the Holland \& Powell dataset, version 6. They allow for forward modelling in the system $\mathrm{Na} 2 \mathrm{O}-\mathrm{CaO}-\mathrm{K}_{2} \mathrm{O}-\mathrm{FeO}-\mathrm{MgO}-\mathrm{Al}_{2} \mathrm{O}_{3}-\mathrm{SiO}_{2}-\mathrm{H}_{2} \mathrm{O}-\mathrm{TiO}_{2}-\mathrm{Fe}_{2} \mathrm{O}_{3}$. In particular, new activity-composition relations are presented for silicate melt of broadly trondhjemitic-tonalitic composition, and for augitic clinopyroxene with $\mathrm{Si}-\mathrm{Al}$ mixing on the tetrahedral sites, while existing activity-composition relations for hornblende are extended to include $\mathrm{K}_{2} \mathrm{O}$ and $\mathrm{TiO}_{2}$. Calibration of the activity-composition relations was carried out with the aim of reproducing major experimental phase-in/phase-out boundaries that define the amphibolite-granulite transition, across a range of bulk compositions, at $\leq 13$ kbar.

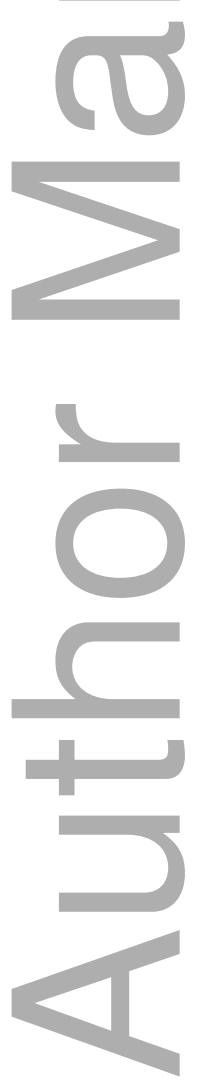

26 Key words: amphibolite; granulite; calibration; pseudosection; Holland \& Powell dataset. 


\section{INTRODUCTION}

The introduction in recent decades of forward modelling via calculated phase diagrams (e.g. Powell \& Holland, 1988; Powell et al., 1998) represents a major development in metamorphic petrology. Suitable phase diagrams, commonly known as pseudosections, map the equilibrium phase assemblages subject to constraints of bulk composition, usually in pressure-temperature $(P-T)$, temperature-bulk composition $(T-X)$ or pressure-bulk composition $(P-X)$ space. To produce such diagrams, the thermodynamics of each of the phases involved must be described by a model. A model consists of one or more end-members, with thermodynamic properties typically taken from an internally-consistent thermodynamic dataset. For multiple-end-member phases, such as solid solutions, the end-member properties must be combined with activity-composition $(a-x)$ relations describing the thermodynamics of mixing of the end-members.

End-member thermodynamic datasets in current use include those of Holland \& Powell (most recently Holland \& Powell, 2011), Berman (1988), Gottschalk (1996) and Chatterjee et al. (1998). The development of model $a-x$ relations for minerals and melts has a long history, with much early work having the purpose of generating thermodynamically-based thermometers and barometers (e.g. Wood \& Banno, 1973; Stormer, 1975; Thompson, 1976; Newton \& Haselton, 1981). Model $a-x$ relations are almost inevitably under-constrained by the available data, and so, when the aim is to calculate phase diagrams, it is sensible to select $a-x$ relations for the various phases that have been parameterised to work together as a set. In this way, deficiencies in the thermodynamic model for one phase may compensate for those in the model for another phase, producing appropriate stable assemblages overall. Widely used sets of $a-x$ relations include those developed for the modelling of metapelitic or ultramafic rocks based on the Holland \& Powell $(1998,2011)$ datasets (e.g. White et al., 2007, 2014; Chu \& Ague, 2013; Holland et al., 2013; Klemme et al., 2009), and those incorporated into the MELTS software and its extensions pMELTS, pHMELTS and 
rhyolite-MELTS, for modelling of partial melting equilibria in ultramafic and felsic systems (Smith \& Asimow, 2005; Ghiorso \& Sack, 1995; Ghiorso et al., 2002; Asimow et al., 2004; Gualda et al., 2012).

Until now, no set of $a-x$ relations has been available for the modelling of partial melting equilibria in metabasic rocks. The current MELTS, pMELTS and rhyolite-MELTS models are not intended to calculate equilibria between melt and amphibole or biotite. $A-x$ relations by e.g. Coggon \& Holland (2002); Diener et al. (2007); Green et al. (2007); Diener \& Powell (2012), founded on the superceded Holland \& Powell (1998) dataset, allow modelling of subsolidus metabasic rocks up to amphibolite and eclogite facies. However, there is no corresponding model for the melt phase; the metapelite melt model of Holland \& Powell $(2001)$ and White et al. $(2007,2014)$ is not parameterised for any but peraluminous, $\mathrm{K}_{2} \mathrm{O}$-rich, CaO-poor felsic melt compositions. Moreover, the $a-x$ relations for several key solid phases are not appropriate for use at granulite-facies temperatures: the hornblende model of Diener et al. (2007) omits $\mathrm{K}_{2} \mathrm{O}$ and $\mathrm{TiO}_{2}$, while the clinopyroxene model of Green et al. (2007) does not allow for $\mathrm{Al}$ on the tetrahedral site, or for $\mathrm{Mg}$ or $\mathrm{Fe}^{2+}$ on the $\mathrm{M} 2$-site.

Our new work fills these gaps. In this paper we provide $a-x$ relations for broadly tonalitic-trondjhemitic silicate melt, high-temperature augitic clinopyroxene, and K-,Ti-bearing hornblende, representing revision and substantial extension of previous models. Other phases that are required for the modelling also appear in metapelitic equilibria, and we have taken the relevant $a-x$ relations from the set of White et al. (2014). The two sets of $a-x$ relations therefore overlap. As a set, the thermodynamic models for metabasite melting equilibria are formally calibrated to $13 \mathrm{kbar}$, and should be used at higher pressures only with sceptical assessment of the results. The 13 kbar limit was imposed due to the lack of a thermodynamic model for aqueous fluid containing a significant proportion of dissolved silicate material, and was inferred from experimental and modelling work on the solubility of silicate minerals (Manning, 1994; Gerya et al., 2005; Manning, 2007; Newton \& Manning, 2008; Dolejš \& Manning, 2010; Hunt \& Manning, 2012). 
This paper presents the development and calibration of the new $a-x$ relations, while in a companion paper (Palin et al., 2016b, this issue), we examine their application to forward modelling in a range of basic to intermediate bulk compositions. Calibration of the $a-x$ relations ultimately made use of experiments in natural systems, modelled in the system $\mathrm{Na}_{2} \mathrm{O}-\mathrm{CaO}-\mathrm{K}_{2} \mathrm{O}-\mathrm{FeO}-\mathrm{MgO}-\mathrm{Al}_{2} \mathrm{O}_{3}-\mathrm{SiO}_{2}-\mathrm{H}_{2} \mathrm{O}-\mathrm{TiO}_{2}-\mathrm{Fe}_{2} \mathrm{O}_{3}$ (NCKFMASHTO). A large body of experimental work has explored phase relations in partially molten metabasic rocks, frequently seeking to determine the origins of tonalite-trondhjemite-granodiorite (TTG) magmas (e.g. Beard \& Lofgren, 1991; Rapp et al., 1991; Rushmer, 1991; Sen \& Dunn, 1994; Wolf \& Wyllie, 1994; Patiño Douce \& Beard, 1995; Rapp \& Watson, 1995; Skjerlie \& Patiño Douce, 1995; Springer \& Seck, 1997; López \& Castro, 2001; Skjerlie \& Patiño Douce, 2002;

Foley et al., 2003; Auzanneau et al., 2006; Qian \& Hermann, 2013; Zhang et al., 2013; Ziaja et al., 2014). During the calibration process, for a subset of the experimental studies, forward calculations of phase relations at the experimental bulk compositions were compared with the observations. The primary goal was to reproduce major phase-in/phase-out boundaries, which, it is hoped, ensures that the behaviour of the models will be broadly realistic in the forward-modelling context for which they are intended.

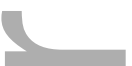

\section{GENERAL NOTES ON THE THERMODYNAMIC MODELS}

The set of $a-x$ relations presented here will be referred to as the 'metabasite set'. It is suitable for use with versions 6.2 or 6.3 of the Holland \& Powell (2011) dataset (ds62, ds63), created 6 February 2012 and 15 January 2015 respectively. The figures in this paper were calculated with version 6.2. The update to version 6.3 includes a key refinement to the thermodynamics of the $\mathrm{H}_{2} \mathrm{O}$ end-member in the melt, and is expected to give slightly more realistic results at the wet solidus. In other respects, differences between calculations with ds62 and ds63 are believed to be insignificant. The $a-x$ relations should not however be 
expected to give meaningful output with the older, widely used version 5.5 (ds55) of the dataset (Holland \& Powell, 1998); indeed ds55 lacks one of the necessary melt end-members. Full descriptions of the $a-x$ relations of the metabasite set appear in the Appendix, along with a guide to downloading the files necessary for using them via the software THERMOCALC (Powell \& Holland, 1988). Calculations in this paper were carried out with THERMOCALC, version tc340i.

This paper will refer to two existing groups of $a-x$ relations used for calculations on metapelitic rocks. The first, the metapelite 'ds55-set', was published by White et al. (2007) for use with version 5.5 of the Holland \& Powell dataset (created 22 November 2003), and has since been slightly modified. The second, the metapelite 'ds6-set', was a major revision of the same models for version 6.1 of the dataset (created 13 November 2011), by White et al. $(2014)$

Abbreviations for the names of end-members are consistent with the Holland \& Powell dataset, and are either explained in the text or defined in the Appendix. End-members that are treated as pure phases are quartz (q), albite (ab), sphene (sph), rutile (ru), and lawsonite (law). The following solution phases appear in the text and figures: actinolite (act), glaucophane (gl), hornblende (hb), orthopyroxene (opx), garnet (g), plagioclase (pl, $C \overline{1}$, and pli, $I \overline{1}$, the latter used for comparison with experiments where $\left.x^{\text {an }}>0.8\right)$, potassium feldspar (ksp), biotite (bi), muscovite (mu), chlorite (chl), silicate melt (L), epidote (ep), ilmenite (ilm), magnetite (mt), and olivine (ol). Additionally five clinopyroxene (cpx) phases are referred to, represented with two different sets of $a-x$ relations. Augitic clinopyroxene (aug) and pigeonite (pig) are considered to have the general formula $\left[\mathrm{Ca}, \mathrm{Na}, \mathrm{Mg}, \mathrm{Fe}^{2+}\right]^{\mathrm{M} 2}\left[\mathrm{Mg}, \mathrm{Fe}^{2+}, \mathrm{Al}, \mathrm{Fe}^{3+}\right]^{\mathrm{M} 1}[\mathrm{Si}, \mathrm{Al}]_{2}^{\text {tet }}$, while diopside (di), jadeite (jd) and omphacite (o) have the general formula $[\mathrm{Ca}, \mathrm{Na}]^{\mathrm{M} 2}\left[\mathrm{Mg}, \mathrm{Fe}^{2+}, \mathrm{Al}, \mathrm{Fe}^{3+}\right]^{\mathrm{M} 1}$ $\mathrm{Si}_{2}^{\text {tet }}$, with omphacite forming via order-disorder on the $\mathrm{M}$ sites.

Among these phases, the $a-x$ relations for metabasite melt (L), augitic clinopyroxene 
(aug and pig) and clinoamphibole (hb, gl and act) are newly calibrated to address partial melting of metabasitic rocks. Of the clinoamphiboles, only hornblende is normally relevant to supersolidus amphibolite-granulite facies conditions, but the new amphibole $a-x$ model is also appropriate for actinolite and glaucophane at lower temperatures. The remaining $a-x$ models in the metabasite set, for the phases garnet, orthopyroxene, feldspar, spinel-magnetite and ilmenite, were taken from the metapelite ds6-set.

Additionally, the existing $a-x$ model for the potentially ordered sodic-calcic pyroxenes jd, di and o (from Green et al., 2007, for use with ds55), has been updated for use with ds6 of the Holland \& Powell dataset (Holland \& Powell, 2011). This model, the 'omphacite' model, remains the appropriate clinopyroxene model to use under subsolidus conditions where co-existing clinopyroxenes might occur. It should not be used in calculations that also involve the augitic clinopyroxene model.

\section{Form of the $a-x$ relations}

Like the metapelite ds55- and ds6-sets, the $a-x$ relations developed in this paper are macroscopic regular solution models, in which non-ideal enthalpic interactions are present between pairs of end-members, expressed as interaction energies $W_{\mathrm{i}, \mathrm{j}}$. The mixing-on-sites approach is adopted, in order to give an approximately correct form for the ideal entropy of mixing. The regular solution paradigm is modified by allowing the $W_{\mathrm{i}, \mathrm{j}}$ in principle to be linear functions of $P$ and $T$, though in practice it is almost never possible to resolve these two dependencies, and the $W_{\mathrm{i}, \mathrm{j}}$ are usually treated as constant or functions of $P$ only. The formulation is discussed extensively by Powell \& Holland (1993) and Holland \& Powell (1996a,b), under the name 'symmetric formalism'. A further modification, the asymmetric formalism (Holland \& Powell, 2003), introduced asymmetry in the manner of van Laar (1906) via 'volume' parameters, $\alpha_{\mathrm{i}}$, associated with each end-member $i$.

In the symmetric formalism, non-ideal contributions to the enthalpy of mixing are 
introduced via activity coefficients written as

$$
\mathrm{R} T \ln \gamma_{1}=-\sum_{i}^{n-1} \sum_{j>i}^{n}\left(p_{\mathrm{i}}^{\prime}-p_{\mathrm{i}}\right)\left(p_{\mathrm{j}}^{\prime}-p_{\mathrm{j}}\right) W_{\mathrm{i}, \mathrm{j}},
$$

where $\gamma_{1}$ is the non-ideal activity coefficient of end-member $\ell, T$ is the temperature, $\mathrm{R}$ is the gas constant, $p_{\mathrm{k}}$ is the proportion of end-member $k$ in the phase, $p_{\mathrm{k}}^{\prime}$ is the value of $p_{\mathrm{k}}$ in end-member $\ell$, such that $p_{\mathrm{k}}^{\prime}=1$ where $k=\ell$ and $p_{\mathrm{k}}^{\prime}=0$ where $k \neq \ell$, and the $n$ end-members in the phase form an independent set. In the asymmetric formalism, the non-ideal contributions are written

$$
R T \ln \gamma_{1}=-\sum_{i}^{n_{-}-1} \sum_{j>i}^{n}\left(\phi_{\mathrm{i}}^{\prime}-\phi_{\mathrm{i}}\right)\left(\phi_{\mathrm{j}}^{\prime}-\phi_{\mathrm{j}}\right) W_{\mathrm{i}, \mathrm{j}}\left(\frac{2 \alpha_{\mathrm{l}}}{\alpha_{\mathrm{i}}+\alpha_{\mathrm{j}}}\right),
$$

where $\phi_{\mathrm{i}}$ is the proportion of end-member $i$ weighted by the van Laar parameters, $\phi_{\mathrm{i}}=\left(p_{\mathrm{i}} \alpha_{\mathrm{i}}\right) /\left(\sum_{k}^{n} p_{\mathrm{k}} \alpha_{\mathrm{k}}\right)$, and $\phi_{\mathrm{i}}^{\prime}$ is likewise the van Laar-weighted equivalent of $p_{\mathrm{i}}^{\prime}$.

The free parameters available for fitting are therefore the $W_{\mathrm{i}, \mathrm{j}}$ and $\alpha_{\mathrm{i}}$ values. In addition, it is sometimes necessary to introduce an expression $\Delta G_{\mathrm{i}}$, which represents an adjustment to the Gibbs energy of end-member $i$ relative to its function $G_{\mathrm{i}}(P, T)$ in the dataset. The $\Delta G_{\mathrm{i}}$ take the form a $+\mathrm{b} T+\mathrm{c} P . \Delta G_{\mathrm{i}}$ expressions were introduced into the metabasite set for a number of reasons:

- $\Delta G_{\mathrm{i}}^{\text {od }}$ represents the $\Delta G$ of ordering. It is applied to an end-member that represents full ordering of cations on sites, at an intermediate composition. It captures the enthalpy change of formation of the ordered intermediate end-member, when it is made by reaction of the end-members at the compositional extremes.

- $\Delta G_{\mathrm{i}}^{\text {mod }}$. This is a modification made to the thermodymamics of a dataset end-member simply in order to improve the behaviour of the $a-x$ relations in phase diagram calculations. A non-zero value may imply that the dataset thermodynamic data for the relevant end-member might be inappropriate, or just that the end-member is accommodating various other deficiencies in the thermodynamic models. 
- $\Delta G_{\mathrm{i}}^{\text {make }}$. Certain minor or 'fictive' end-members in the $a-x$ models do not appear in the dataset. To approximate their $G_{\mathrm{i}}(P, T)$ functions, a linear combination of dataset end-members is chosen that produces the right composition. The $G(P, T)$ functions of these end-members are combined likewise, and a $\Delta G_{\mathrm{i}}^{\text {make }}$ expression is added that can be calibrated to represent the $\Delta G$ between the combination of dataset end-members and the fictive end-member.

- $\Delta G_{\mathrm{i}}^{\text {tran }}$. This is a special case of $\Delta G_{\mathrm{i}}^{\text {make }}$, in which a first order phase transition separates end-member $i$ from dataset end-member $j$ of the same composition but different symmetry. Then $\Delta G_{\mathrm{i}}^{\text {tran }}$ represents $\Delta G$ of the $i-j$ transition.

Examples of all of these appear in the $a-x$ relations in the Appendix.

This paper adopts the following notational conventions: (1) as $W_{\mathrm{i}, \mathrm{j}} \equiv W_{\mathrm{j}, \mathrm{i}}$, either notation may be used for a given pair of end-members; (2) the interaction energies between an end-member $i$ and multiple, specified end-members $j, k, \ldots$ in the same phase are represented as $W_{\mathrm{i},[\mathrm{j}, \mathrm{k}, \ldots . .]} ;(3)$ the expression $W_{\mathrm{i}, n}$, or $W_{\mathrm{iL}, n \mathrm{~L}}$ for the liquid model, represents the set of $W_{\mathrm{i}, \mathrm{j}}$ parameters between end-member $i$ and all of the other end-members in the same $a-x$ model.

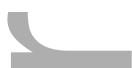

\section{Calibration strategy}

The root of the calibration approach was the fitting of key parameters in small, well-constrained chemical subsystems. Thus, each of the new $a-x$ models has a core in a major subsystem that was developed independently of the other new models. The models were then completed sequentially. First the augite model was developed entirely in amphibole-free and melt-free assemblages. Then the clinoamphibole model was completed based on calculations in which the augite model was treated as fixed. Finally, both the augite and clinoamphibole $a-x$ relations were treated as fixed, while the melt model was completed based on observations from a selection of experimental studies on 
TTG-generation. The choice of TTG-generation studies was limited to those with multiple hydrate-breakdown melting runs at $\leq 13$ kbar, placing constraints on significant phase-in/phase-out boundaries, with bulk compositions that could reasonably be modelled in NCKFMASHTO (for example, they should be nominally carbon-free).

In general (for variance $>2$ ), the calculations performed during the calibration process mimicked those performed when the finished models are used; they were forward calculations that gave the compositions and modal proportions of phases at equilibrium, subject to the constraint of the experimental bulk composition. In some cases the calculations took place at the $P-T$ conditions of an experiment, for direct comparison with the experimental run products. However, the highest priority for the calibration was to make good predictions of the major features of phase relations across $P-T$ space, rather than to make accurate predictions of phase compositions. Consequently, the interpolated positions of key phase field boundaries (e.g. orthopyroxene-in, hornblende-out) were used directly in calibration. The final step in calibration was to calculate full $P-T$ pseudosections for key experimental bulk compositions, ensuring that the assemblages specified during the calibration were the most stable that could be modelled.

Calibrations that are new in this work were carried out either by manual trial and error or by using a Monte Carlo method, MCTC, within the THERMOCALC software. When MCTC is invoked, THERMOCALC calculates a set of phase equilibria repeatedly, using $a-x$ models with parameters drawn randomly from within specified distributions. 'Successful' sets of model parameters are identified by comparing the resulting calculated phase equilibria with the observations, and the distribution of successful model parameters is reviewed, leading to refinement of the initial distribution. Over the course of many MCTC runs, the user will first widen the initial distributions of model parameters until, for each parameter, a peak is visible in the distribution of successful values. Then, certain model parameters may be given fixed values, especially those that are weakly constrained (their 'successful' distributions are wide), or strongly correlated with other parameters. The distributions of 
all parameters are narrowed over time, with the aim of deriving quasi-optimised values.

The MCTC approach is thus a hybrid between manual trial and error and a formal, automated technique. It robustly handles two problems: the very high and multi-dimensional correlations among successful distributions of model parameters, and the presence of parameters that are essentially unconstrained by the data. A fitting method that does not take these phenomena into account is at risk of generating physically implausible parameter values, leading to $a-x$ relations that do not extrapolate well in $P-T-X$ space.

In order to use phase equilibrium experiments as constraints, it is necessary to infer bulk compositions that represent the experimental run products at equilibrium. Two components of bulk composition in particular are hard to estimate: those of fluid content, assumed to be all water ('molar bulk $\mathrm{H}_{2} \mathrm{O}$ ', $M_{\mathrm{H}_{2} \mathrm{O}}$ ), and of oxygen ('molar bulk $\mathrm{O}$ ', $M_{\mathrm{O}}$ ). Experimental studies routinely provide estimates of $\mathrm{H}_{2} \mathrm{O}$ content in the starting material, though these are uncertain, and unlikely to include $\mathrm{H}_{2} \mathrm{O}$ gained by adsorption during the pulverisation of the sample, which may be retained even during storage under desiccation (London et al., 2012). $M_{\mathrm{O}}$ may be equated directly to molar bulk $\mathrm{Fe}_{2} \mathrm{O}_{3}$, via the reaction $\mathrm{Fe}_{2} \mathrm{O}_{3}=2 \mathrm{FeO}+\mathrm{O}$, if iron is the only element considered to have variable oxidation state. The fraction of iron present as $\mathrm{Fe}_{2} \mathrm{O}_{3}$ in the starting material is rarely estimated. During experimental runs, values of $M_{\mathrm{H}_{2} \mathrm{O}}$ and $M_{\mathrm{O}}$ in the capsule are subject to interdependent changes. The experiments considered in this work were not formally buffered to specified $f \mathrm{O}_{2}$, but even in such cases, the experimental apparatus has an 'intrinsic $f \mathrm{O}_{2}$ ' that influences the oxidation state of the starting material during the run; hence $M_{\mathrm{O}}$ is not conserved. The process of oxidation or reduction of starting materials primarily involves diffusion of $\mathrm{H}_{2}$, to which experimental capsules are effectively open. If the apparatus provides an environment that is reducing with respect to the oxidation state of the starting materials, $\mathrm{H}_{2}$ will enter the capsule and may form $\mathrm{H}_{2} \mathrm{O}$ by reduction of iron oxides, constituting an increase in $M_{\mathrm{H}_{2} \mathrm{O}}$ and decrease in $M_{\mathrm{O}}$ (carbon, derived from graphite furnaces, may play a under-acknowledged role in this process; see Brooker et al., 1998; 
Jakobsson, 2012; Matjuschkin et al., 2015). Finally, apparent loss or gain of both $\mathrm{H}_{2}$ and $\mathrm{O}_{2}$, or possibly molecular $\mathrm{H}_{2} \mathrm{O}$, has has been reported in several piston cylinder studies (e.g. Patiño Douce \& Beard, 1994, 1995; Truckenbrodt \& Johannes, 1999; Pichavant et al., 2002; Jakobsson, 2012), especially during longer and higher-temperature experiments.

There is therefore no satisfactory way to convert the information reported in an experimental study into values of $M_{\mathrm{O}}$ and $M_{\mathrm{H}_{2} \mathrm{O}}$ suitable for a representative pseudosection. A crucial part of the model calibration, then, is to analyse the sensitivity of calculations to the assumed values of $M_{\mathrm{O}}$ and $M_{\mathrm{H}_{2} \mathrm{O}}$. This is done most informatively by calculating $T-X$ or $P-X$ pseudosections, in which $X$ is $M_{\mathrm{O}}$ or $M_{\mathrm{H}_{2} \mathrm{O}}$.

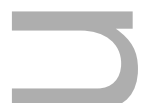

\section{CLINOPYROXENE $A-X$ RELATIONS}

\section{Omphacite model}

The 'omphacite model' of Green et al. (2007), modified by Diener \& Powell (2012), was developed with the aim of modelling coexisting jadeite-omphacite and omphacite-diopside pairs. Previously calibrated with ds55, it was upgraded in this work for use with version 6 of the Holland \& Powell dataset. It remains the only appropriate choice of $a-x$ relations wherever diopsidic and sodic clinopyroxenes may stably coexist, since the new augitic clinopyroxene model is intended for use at temperatures higher than the closure of the jadeite-omphacite and omphacite-diopside miscibility gaps, and has no capacity to represent the ordered omphacite structure.

The omphacite model allows for cation mixing as $\left[\mathrm{Mg}, \mathrm{Fe}^{2+}, \mathrm{Al}, \mathrm{Fe}^{3+}\right]^{\mathrm{M} 1}$ and $[\mathrm{Ca}$, $\mathrm{Na}]^{\mathrm{M} 2}$, but in order to represent ordered intermediate end-members such as omphacite $\left(\mathrm{Ca}_{\frac{1}{2}}^{\mathrm{M} 2} \mathrm{Na}_{\frac{1}{2}}^{\mathrm{M} 2} \mathrm{Mg}_{\frac{1}{2}}^{\mathrm{M} 1} \mathrm{Al}_{\frac{1}{2}}^{\mathrm{M} 1} \mathrm{Si}_{2}^{\text {tet }} \mathrm{O}_{6}\right)$, it treats the M1 and M2 sites as 'split'. That is, $\mathrm{Mg}, \mathrm{Fe}^{2+}$, $\mathrm{Al}$ and $\mathrm{Fe}^{3+}$ mix on a M1m and a M1a site, with cations preferentially partitioned onto the 
M1m site in the order $\mathrm{Fe}^{2+}>\mathrm{Mg}>\mathrm{Al}>\mathrm{Fe}^{3+}$, while $\mathrm{Ca}$ and $\mathrm{Na}$ mix on a M2c and a M2n site, with Ca preferentially partitioned onto M2c (Green et al., 2007). The tetrahedral sites contain Si only.

Slight modifications were needed in order to compensate for the change from version 5.5 to version 6 of the dataset. Following Diener \& Powell (2012), modifications were made simultaneously for both the omphacite model, and the NCFMASHO core of the ds55 clinoamphibole model of Diener et al. (2007; refined by Diener \& Powell, 2012). For the omphacite model, the modification amounted to a change in $\Delta G_{\mathrm{acm}}^{\mathrm{mod}}$ on the acmite end-member, from -4 to $-7 \mathrm{~kJ}$. The change was determined by manually adjusting the $\Delta G_{\mathrm{i}}^{\mathrm{mod}}$ values of end-members in both models, until satisfactory calculations were obtained for equilibria in a MORB-like composition (composition Mcal, Table $1, \mathrm{H}_{2} \mathrm{O}$ in excess).

The $W_{\mathrm{i}, \mathrm{j}}$ parameters were left unchanged from the previous version of the omphacite model, since these-were relatively well constrained by the observed geometry of the solvi between the diopsidic, omphacitic and jadeitic portions of the solid solution. Conversely, since the solvi depend solely on the mixing properties of the models, rather than the end-member thermodynamics, solvus calculations will be unchanged from the previous model.

\section{Augite model}

Prompted by the compositions of clinopyroxene in TTG-genesis experiments (e.g. Patiño Douce \& Beard, 1995; Skjerlie \& Patiño Douce, 2002; Rapp \& Watson, 1995), a new 'augite model' was developed for calcic clinopyroxene at high temperature, with mixing on sites as $\left[\mathrm{Mg}, \mathrm{Fe}^{2+}, \mathrm{Al}, \mathrm{Fe}^{3+}\right]^{\mathrm{M} 1}\left[\mathrm{Ca}, \mathrm{Na}, \mathrm{Mg}, \mathrm{Fe}^{2+}\right]^{\mathrm{M} 2}[\mathrm{Si}, \mathrm{Al}]_{2}^{\text {tet }}$. This model is not consistent with the omphacite model, even though the models overlap in composition space, and the two should not be used in the same calculation. In particular, the simple M1 and M2 sites of the augite model do not not allow order-disorder to take place on either of these sites 
individually, unlike the split M1 and M2 sites of the omphacite model. In partial compensation for this, different values of $\Delta G^{\text {mod }}$ are used for some end-members that are common to both models.

The heart of the augite model is the pyroxene quadrilateral

$\mathrm{CaMgSi}_{2} \mathrm{O}_{6}-\mathrm{Mg}_{2} \mathrm{Si}_{2} \mathrm{O}_{6}-\mathrm{Fe}_{2} \mathrm{Si}_{2} \mathrm{O}_{6}-\mathrm{CaFeSi}_{2} \mathrm{O}_{6}$. Figure 1 shows the modelled fit to the experimental work of Lindsley $(1981,1983)$ and Turnock \& Lindsley (1981) on clinopyroxene-orthopyroxene equilibria in this system, including the binary subsystem $\mathrm{CaFeSi}_{2} \mathrm{O}_{6}-\mathrm{Fe}_{2} \mathrm{Si}_{2} \mathrm{O}_{6}$. The clinopyroxene $a-x$ relations cover the whole of the quadrilateral composition space, with the compositional end-members in appropriate $C 2 / c$ symmetry being diopside (di), clinoenstatite (cenh), clinoferrosilite (cfs) and hedenbergite (hed). The clinoenstatite and clinoferrosilite end-members are polymorphs that exist at low-pressure, high-temperature in the unary systems, and their stability fields and properties are little known. They are generated via $\Delta G^{\text {tran }}$ expressions from the Pbca end-members en (enstatite) and fs (ferrosilite) in the Holland \& Powell dataset. An ordered intermediate end-member, fmc $\left(\mathrm{Mg}^{\mathrm{M} 1} \mathrm{Fe}^{\mathrm{M} 2} \mathrm{Si}_{2} \mathrm{O}_{6}\right)$, allows non-equal partitioning of $\left[\mathrm{Mg}, \mathrm{Fe}^{2+}\right]$ over the M1 and M2 sites (Holland \& Powell, 2006). Since a reaction di $+\frac{1}{2} \mathrm{cfs}=$ hed $+\frac{1}{2}$ cenh can be written among the compositional end-members, the thermodynamic properties of one must be treated as dependent, and hedenbergite was chosen for this purpose. Values for model parameters on the $\mathrm{CaMgSi}_{2} \mathrm{O}_{6}-\mathrm{Mg}_{2} \mathrm{Si}_{2} \mathrm{O}_{6}$ join, including $\Delta G_{\text {cenh }}^{\text {tran }}$, were taken from the CMAS clinopyroxene model of Green et al. (2012a), where they were calibrated against the experimental work of Brey \& Huth (1984); Carlson \& Lindsley (1988); Lindsley \& Dixon (1976); Mori \& Green (1975); Nickel \& Brey (1984); Perkins \& Newton (1980) and Schweitzer (1982).

The MCTC function in THERMOCALC was used to fit the additional CFMS parameters $W_{\mathrm{di},[\mathrm{cfs}, \mathrm{fmc}]}, W_{\mathrm{cenh},[\mathrm{cfs}, \mathrm{fmc}]}, W_{\mathrm{cfs}, \mathrm{fmc}}, \Delta G_{\mathrm{cfs}}^{\mathrm{tran}}$ and $\Delta G_{\mathrm{fmc}}^{\mathrm{od}}$. The pressure dependence of the inherited CMAS parameter $W_{\mathrm{di}, \text { cenh }}$ was applied to $W_{\mathrm{di},[\mathrm{cfs}, \mathrm{fmc}]} . \Delta G_{\mathrm{cfs}}^{\mathrm{tran}}$ was assumed to have the same temperature dependence as $\Delta G_{\text {cenh }}^{\text {tran }}$, and was required to give a fs $=$ cfs transition 
curve consistent with the estimation of Lindsley (1981). $\Delta G_{\mathrm{fmc}}^{\text {od }}$ took the mean pressure and temperature dependencies of $\Delta G_{\text {cenh }}^{\text {tran }}$ and $\Delta G_{\mathrm{cfs}}^{\mathrm{tran}}$, with the constant term fitted such that the ordered end-member fmc was more stable than its fully disordered equivalent, $\mathrm{Mg}_{\frac{1}{2}}^{\mathrm{M} 1} \mathrm{Fe}_{\frac{1}{2}}^{\mathrm{M} 1} \mathrm{Mg}_{\frac{1}{2}}^{\mathrm{M} 2} \mathrm{Fe}_{\frac{1}{2}}^{\mathrm{M} 2} \mathrm{Si}_{2} \mathrm{O}_{6}$, for which $G$ is given by $\frac{1}{2}\left(G_{\text {cenh }}+G_{\mathrm{cfs}}\right)$. At $900^{\circ} \mathrm{C}$ and $8 \mathrm{kbar}$, the dependent value of $G_{\text {hed }}$ was constrained to be within $2 \mathrm{~kJ} / \mathrm{mol}$ of the ds62 dataset value, with a further constraint of $G_{\text {hed }}<G_{\text {ohed }}$. $G_{\text {ohed }}$ is the $G$ function for the $P b c a$-symmetry orthohedenbergite end-member, derived from the quadrilateral $a-x$ relations for orthopyroxene in the same way as $G_{\text {hed }}$ is derived for the hedenbergite end-member in clinopyroxene; thus the latter condition specified that the monoclinic polymorph was the more stable of the two.

The resulting fit successfully reproduces augite-orthopyroxene tielines in the quadrilateral, and is notably successful at matching the very sensitive divariant augite-pigeonite - orthopyroxene equilibrium at $15 \mathrm{kbar}, 1000^{\circ} \mathrm{C}$ (Fig. 1). It somewhat overestimates the width of the augite-pigeonite solvus towards higher $\mathrm{FeO} /(\mathrm{FeO}+\mathrm{MgO})$ values.

The quadrilateral model was then combined with the CMAS clinopyroxene model of Green et al. (2012a), introducing the end-member Ca-tschermak's pyroxene (cats; $\mathrm{CaAl}_{2} \mathrm{SiO}_{6}$ ) and associated parameters, which allowed for the substitution of $\mathrm{Al}$ onto the M1 and tetrahedral sites simultaneously. The cats end-member exhibits internal order-disorder of Si-Al on the tetrahedral site, with the energy and entropy of disordering reduced by a factor of 4 (Holland \& Powell, 2011). Finally, the end-members jadeite (jd) and acmite $(\mathrm{acm})$ were added to the model to accommodate $\mathrm{Na}, \mathrm{Fe}^{3+}$, and an excess of $\mathrm{Al}$ on the M1 site relative to the tetrahedral site. Values for $W_{\mathrm{di}, \mathrm{jd}}, W_{\mathrm{di}, \mathrm{acm}}$ and $W_{\mathrm{jd}, \mathrm{acm}}$ were adopted from the omphacite model. However, the jd and acm end-members serve a different role in the augite model from in the omphacite model. In the augite model, they are simply required to admit minor components, whereas in the omphacite model, they may be present in substantial proportions, with order-disorder between sodic and calcic end-members 
contributing heavily to the thermodynamics of mixing. Consequently it is not very significant that the values of the dependent $W_{\text {hed, } n}$ parameters in the augite model differ from their independently-calibrated equivalents in the omphacite model (values are compared in the Appendix). With the same justification a $\Delta G_{\mathrm{jd}}^{\text {mod }}$ term was added to the augite jd end-member, and different $\Delta G_{\mathrm{acm}}^{\mathrm{mod}}$ terms were used in the augite and omphacite models.

In addition to $\Delta G_{\mathrm{jd}}^{\mathrm{mod}}$ and $\Delta G_{\mathrm{acm}}^{\mathrm{mod}}$, the free parameters in this second stage of augite model calibration were $W_{\text {cats, },[\mathrm{cfs}, \mathrm{fmc}]}, W_{\mathrm{jd},[\mathrm{cenh}, \mathrm{cfs}, \mathrm{fmc}, \mathrm{cats}]}$ and $W_{\mathrm{acm},[\mathrm{cenh}, \mathrm{cfs}, \mathrm{fmc}, \mathrm{cats}]}$. These interaction energies were not expected to be influential compared with the $\Delta G_{\mathrm{i}}^{\text {mod }}$ terms, so a small number of observed equilibria were carefully chosen to be fitted, primarily with the purpose of finding values for $\Delta G_{\mathrm{jd}}^{\mathrm{mod}}$ and $\Delta G_{\mathrm{acm}}^{\mathrm{mod}}$. The chosen equilibria comprised two natural rock samples, with estimated $P$ and $T$ values, and one experiment; Table 2 shows the equilibria and results. The process of fitting with MCTC revealed very strong multicomponent correlations among the interaction energies. It was not clear a priori that these correlations would be relevant for model calculations in general, but in fact, in later calculations on melting equilibria, it was found that violating the correlations for apparently trivial parameters such as $W_{\text {cats,fmc }}$ did indeed have a large and detrimental effect on the calculated compositions of all phases, particularly the anorthite content $x^{\text {an }}$ in plagioclase.

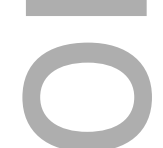

\section{Calculations with the augite versus omphacite models}

Figure 2 shows pseudosections calculated for an oxidised MORB composition, based on that of Sun \& McDonough (1989; SM89, Table 1), in the range $450-700^{\circ} \mathrm{C}$ and $4-20 \mathrm{kbar}$. The figure is contoured for $x_{\mathrm{Na}}^{\mathrm{M} 2}$ in clinopyroxene. Calculations were carried out with first the augite model (Fig. 2a,b) and then the omphacite model (Fig. 2c,d), in order to compare the two. The comparison demonstrates, firstly, that the omphacite model is the appropriate choice for the relatively low temperatures shown. When modelling is done correctly using 
the omphacite model (Fig. 2c,d), $x_{\mathrm{Na}}^{\mathrm{M} 2}$ in clinopyroxene rises to $>0.4$ towards higher pressures, and the diopside-omphacite solvus is visible at several pressures with closure at $\sim 600^{\circ} \mathrm{C}$. Meanwhile the augite model has no capacity to model omphacite-like Na contents or coexistence between omphacitic and diopsidic compositions, so no solvus appears in Figs $2 \mathrm{a}$ and b. Secondly, it can be seen that the two models give substantially consistent results for $P<13$ kbar and $T>600^{\circ} \mathrm{C}$, where the omphacite model takes on an augitic composition. Phase field boundaries in this region in Figs 2a and c show agreement within $20^{\circ} \mathrm{C}$, while the augite model gives values of $x_{\mathrm{Na}}^{\mathrm{M} 2}$ that are consistently lower than the omphacite model by $\sim 0.05$, within the likely uncertainty in the modelling.

The nature of phase relations in Fig. 2c are discussed in a later section. Subsequent figures will demonstrate the behaviour of the augite model in the $P<13 \mathrm{kbar}, T>600^{\circ} \mathrm{C}$ regime for which it was calibrated.

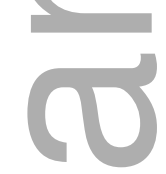

\section{CLINOAMPHIBOLE $A-X$ RELATIONS}

The clinoamphibole model of Diener et al. (2007) and Diener \& Powell (2012), in

NCFMASHO, is suitable for calculations on metabasic rocks under subsolidus conditions, using version 5.5 of the dataset (Holland \& Powell, 1998). As described above, it was updated for use with version 6.2 in conjunction with the omphacite model, by adjustments to the end-member thermodynamics. The resulting modifications affected the following end-members: pargasite $\left(\Delta G_{\text {parg }}^{\text {mod }}\right.$ changed from $15 \mathrm{~kJ}$ to $\left.-10 \mathrm{~kJ}\right)$, glaucophane $\left(\Delta G_{\mathrm{gl}}^{\mathrm{mod}}\right.$ changed from $3 \mathrm{~kJ}$ to $-3 \mathrm{~kJ})$, cummingtonite $\left(\Delta G_{\text {cumm }}^{\mathrm{mod}}\right.$ changed from $-6.4 \mathrm{~kJ}$ to $\left.0 \mathrm{~kJ}\right)$, grunerite $\left(\Delta G_{\text {grun }}^{\text {mod }}\right.$ changed from $-5 \mathrm{~kJ}$ to $\left.-3 \mathrm{~kJ}\right)$ and magnesioriebekite $\left(\Delta G_{\mathrm{mrb}}^{\text {make }}\right.$ changed from $8 \mathrm{~kJ}$ to $0 \mathrm{~kJ}$ ). These were pleasing in that generally the absolute values of the $\Delta G_{\mathrm{i}}^{\text {mod }}$ terms decreased, making the end-member $G$ curves more similar to the dataset functions. 
By granulite facies temperatures, the components $\mathrm{K}_{2} \mathrm{O}$ and $\mathrm{TiO}_{2}$ are significant in hornblende (e.g. Robinson et al., 1982). The core model was therefore expanded to include the components $\mathrm{K}_{2} \mathrm{O}$ and $\mathrm{TiO}_{2}$, with the intention that the full model in NCKFMASHTO would be applicable both above and below the solidus. $\mathrm{K}_{2} \mathrm{O}$ was introduced via a potassium-pargasite end-member (kprg, $\left.\mathrm{KCa}_{2} \mathrm{Mg}_{4} \mathrm{Al}_{3} \mathrm{Si}_{6} \mathrm{O}_{22}(\mathrm{OH})_{2}\right)$, such that $\mathrm{K}^{+}$mixes with $\mathrm{Na}^{+}$on the partially filled model A site. A deprotonation-style substitution was adopted to introduce $\mathrm{TiO}_{2}$ via an end-member Ti-tschermakite (tts, $\mathrm{Ca}_{2} \mathrm{Mg}_{3} \mathrm{Ti}_{2} \mathrm{Al}_{2} \mathrm{Si}_{6} \mathrm{O}_{22}$ ), allowing hornblende to persist to higher temperatures in equilibrium with melt by lowering its water activity $a\left(\mathrm{H}_{2} \mathrm{O}\right)$, although in reality the substitution whereby $\mathrm{TiO}_{2}$ enters metamorphic hornblende is more likely to be a tschermakite-like and/or glaucophane-like substitution (Schumacher, 2007). The new end-members tts and kprg are not present in the Holland \& Powell dataset, but are made via the reactions $\mathrm{kprg}=\mathrm{mu}-\mathrm{pa}+\mathrm{parg}+$ $\Delta G_{\mathrm{kprg}}^{\mathrm{make}}$ and $\mathrm{tts}=\mathrm{dsp}-2 \mathrm{ru}+\mathrm{ts}+\Delta G_{\mathrm{tts}}^{\text {make }}(\mathrm{mu}:$ muscovite; pa: paragonite; ru: rutile; dsp: diaspore)

A key equilibrium is the first introduction of hornblende and glaucophane to the assemblage act $+\mathrm{chl}+\mathrm{ep}+\mathrm{ab}+\mathrm{sph}+\mathrm{q}+\mathrm{H}_{2} \mathrm{O} \pm$ bi, i.e. the junction of the greenschist, blueschist and amphibolite facies. This occurs at around $8-10 \mathrm{kbar}$ and $450-500^{\circ} \mathrm{C}$ on most metamorphic facies diagrams. The presence of three coexisting amphiboles in this equilibrium make the calculated values of $P, T$ and compositional variables extremely sensitive to the parameterisation of the amphibole $a-x$ relations. It was required that minimal amounts of $\mathrm{K}_{2} \mathrm{O}$ and $\mathrm{TiO}_{2}$ should be taken into the amphiboles at this temperature, but the prejudice was nevertheless imposed that the amphibole phases would incorporate $\mathrm{K}_{2} \mathrm{O}$ in the order $\mathrm{hb}>\mathrm{gl} \approx$ act, and $\mathrm{TiO}_{2}$ in the order $\mathrm{hb} \approx \mathrm{gl}>$ act. The full list of $P-T$ and compositional constraints placed on this equilibrium during fitting, and the results obtained, are given in Table 3. The table also compares calculations and observations for several upper-amphibolite facies rocks, for which likely values of $P, T$ and $M_{\mathrm{O}}$ have been established by previous calculations with older versions of the models. Since 
some of these equilibria contain clinopyroxene, this was also an opportunity to check the behaviour of the ds6-omphacite and augite models.

Fitting was carried out in MCTC, to find values for $\Delta G_{\mathrm{kprg}}^{\mathrm{make}}, \Delta G_{\mathrm{tts}}^{\mathrm{make}}$, and the new interaction energies $W_{\mathrm{kprg}, n}$ and $W_{\mathrm{tts}, n}$. Because the number of interaction energies to be fitted was large, and they were expected to be poorly constrained due to the small amounts of the $\mathrm{K}_{2} \mathrm{O}$ and $\mathrm{TiO}_{2}$ end-members present, the fitting problem was initially reduced by assuming that $\mathrm{K}^{+}$and $\mathrm{Na}^{+}$would mix with similar energetic consequences on the A-site, and therefore fixing values of $W_{\mathrm{parg}, \mathrm{kprg}}=0$ and $W_{\mathrm{kprg}, n}=W_{\mathrm{parg}, n}$. The possibility of allowing other, less well constrained parameters to vary in order to improve the fit was also explored. Ultimately however, better results were obtained by allowing the $W_{\mathrm{kprg}, n}$ parameters to diverge from the equivalent $W_{\text {parg,n }}$ values by up to $5 \mathrm{~kJ}$, while the parameters from the core NCFMASHO model could not convincingly be improved upon. The asymmetry of interactions was inherited from the Diener et al. (2007) model, with the addition of the terms $\alpha_{\mathrm{kprg}}=\alpha_{\mathrm{parg}}$ and $\alpha_{\mathrm{tts}}=\alpha_{\mathrm{ts}}$. As in the Diener et al. (2007) model and the new augite model, the entropy of $\mathrm{Si}-\mathrm{Al}$ mixing on the tetrahedral sites was reduced by a factor of 4 .
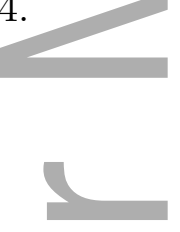

\section{CALCULATIONS ON SUBSOLIDUS PHASE RELATIONS}

We now return to Fig. 2c, a pseudosection calculated between greenschist-blueschist facies conditions and the solidus using the metabasite set of $a-x$ relations, with the omphacite model representing clinopyroxene. The bulk composition (SM89, Table 1) is based on the MORB composition of Sun \& McDonough (1989), but considerably oxidised, with $X_{\mathrm{Fe}^{3+}}=$ $\mathrm{Fe}^{3+} /\left(\mathrm{Fe}^{2+}+\mathrm{Fe}^{3+}\right)=0.36$. The same bulk composition was previously used by Diener \& Powell (2012), fig. 1c, allowing the ds55 and ds6x generations of $a-x$ relations to be 
compared.

Subsolidus phase relations in the greenschist and amphibolite facies remain similar, with hornblende replacing actinolite and chlorite at $\sim 480^{\circ} \mathrm{C}$ as in the older calculations, and diopside now joining the assemblage at $\sim 550^{\circ} \mathrm{C}$ rather than $600^{\circ} \mathrm{C}$. Calculations at $12-20$ kbar and $<550^{\circ} \mathrm{C}$ now generate gl + act + chl + ep \pm law \pm o assemblages that resemble natural blueschists, whereas the ds 55 generation of $a-x$ relations found omphacite stable rather than glaucophane. At 16-20 kbar, between 530 and $580^{\circ} \mathrm{C}$, the blueschist assemblages give way to higher-temperature eclogite assemblages containing garnet, omphacite and hornblende.

Phase relations below $650^{\circ} \mathrm{C}$ are negligibly affected if the $\mathrm{K}_{2} \mathrm{O}$ and $\mathrm{TiO}_{2}$ components are excluded from amphibole. The Diener \& Powell (2012) figure was calculated without a melt phase, since no suitable melt $a-x$ relations existed at that time; the new figure, using the metabasite melt model described in the next section, shows the start of $\mathrm{H}_{2} \mathrm{O}$-saturated melting at $615-700^{\circ} \mathrm{C}$

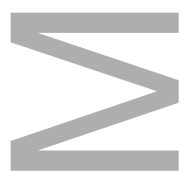

\section{MELT $A-X$ RELATIONS}

Existing silicate melt $a-x$ relations for use with the Holland \& Powell dataset include the ds5 haplogranitic model of Holland \& Powell (2001), its expansion into NCKFMASH for use in metapelite melting calculations (White et al., 2001, 2007), the ds6 equivalent of the metapelite melt model (White et al., 2014), and the mafic melt model of Jennings \& Holland (2015). These models are exceedingly simple, reproducing the macroscopic mixing properties of melt over a limited compositional range while making no attempt to capture melt speciation, or otherwise to separate the enthalpic and entropic contributions in the models in a way that resembles reality. Like the $a-x$ relations for solid solutions, the melt is 
treated as a regular solution with the non-ideal enthalpy of mixing expressed using the symmetric formalism. The end-members are mineral-like compounds that mix as molecules.

The metapelite melt model has proved very successful in calculations (e.g. White et al., 2001, 2007; Grant, 2009; Johnson et al., 2008; White et al., 2011). It is desirable that the new metabasite melt model and the metapelite melt model should share a core in NKASH, defined by the end-members $q \mathrm{~L}-\mathrm{abL}-\mathrm{kspL}-\mathrm{h} 2 \mathrm{oL}$ (see Appendix for end-member definitions). However, with respect to the $\mathrm{CaO}, \mathrm{FeO}$ and $\mathrm{MgO}$ components, the metabasite melt model requires a different parameterisation and structure from the metapelite model, in order to allow the melt composition to become sufficiently calcic, and to become metaluminous if required.

The $\mathrm{qL}-\mathrm{abL}-\mathrm{kspL}$ subsystem of the White et al. (2014) metapelite melt model was strongly constrained by the experiments of Boyd \& England (1963); Lindsley (1966); Ostrovsky (1966) and Jackson (1976), and could be retained without change to form the core of the metabasite melt model. In the $\mathrm{qL}-\mathrm{abL}-\mathrm{kspL}-\mathrm{h} 2 \mathrm{oL}$ subsystem, a number of changes are planned for a forthcoming revision of the White et al. (2014) metapelite melt model, and these have been incorporated directly into the metabasite melt model as presented in this study. The changes to the $\mathrm{qL}-\mathrm{abL}-\mathrm{kspL}-\mathrm{h} 2 \mathrm{oL}$ core, relative to the White et al. (2014) version of the metapelite melt model, are as follows. (1) The interaction energies $W_{\mathrm{h} 20 \mathrm{~L},[\mathrm{qL}, \mathrm{abL}, \mathrm{kspL}]}$ have been refined by comparison with the subsystem experiments of Behrens (1995); Kennedy et al. (1962); Stewart (1967); Goldsmith \& Peterson (1990) and Goldsmith \& Jenkins (1985). (2) In ds63, the constant-pressure heat capacity of the h2oL end-member has been lowered to improve the calculated $\mathrm{H}_{2} \mathrm{O}$ isopleths for melts. In fig. 9 of Holland \& Powell (2001) the $\mathrm{H}_{2} \mathrm{O}$ isopleths in granitic liquid are spuriously concave downwards in pressure, as a result of too high a heat capacity for h2oL; this heat capacity has now been optimised such that the isopleths become approximately straight lines, as required by the experimental data of Holtz et al. (1995). (3) The formula of the end-member silL has been changed from $\frac{8}{5} \mathrm{Al}_{2} \mathrm{SiO}_{5}$ to $\mathrm{Al}_{2} \mathrm{SiO}_{5}$. 
In the metapelite model, the Ca-rich vertex of composition space is represented by the anorthite-liquid end-member, anL, but the metabasite model has been extended as far as a wollastonite-liquid end-member, woL, in order to encompass metaluminous compositions. However, the woL end-member is compositionally distant from the melts of metabasic rocks, and its thermodynamics are poorly constrained. To compensate for this, an anL-composition end-member was restored to the metabasite melt model in the form of an ordered intermediate, made via the reaction anL $=$ woL + silL with a $\Delta G_{\text {anL }}^{\text {od }}$ term applied. The thermodynamic properties of $\mathrm{CaAl}_{2} \mathrm{Si}_{2} \mathrm{O}_{8}$-composition liquid were approximated by fitting to the anorthite melting curve. This aspect of the model structure follows e.g. Hastie (1983); Hastie \& Bonnell (1985); Bonnell \& Hastie (1985); Besmann \& Spear (2002) and Green et al. (2012b), in which the ordered intermediate end-members are termed 'associate species'. The inclusion of an ordered intermediate end-member, intL, in the melt $a-x$ relations adds flexibility in fitting the available constraints, since the $\Delta G_{\text {intL }}^{\text {od }}$ term provides a free parameter and the presence of the intL compound contributes to model entropy. However it should be stressed that speciation is not represented in any meaningful way in the metabasite melt model, either by the choice of end-member mixing units or by the ordering taking place among them.

To complete the calibration of the metabasite melt model, values had to be found for $\Delta G_{\mathrm{anL}}^{\mathrm{od}}$ and the new interaction energies $W_{\mathrm{woL}, n \mathrm{~L}}$ and $W_{\mathrm{anL}, n \mathrm{~L}}$. Parameters such as $W_{\mathrm{anL}, \mathrm{qL}}$ are not strictly the same as the equivalently-named parameter in the metapelite melt model, because the anL end-member in the metabasite melt model is not the dataset end-member but an 'ordered' end-member that coexists with a 1:1 mixture of woL + silL 'molecules', even at the anorthite composition. Due to the significant difference in composition range between the metapelite and metabasite melt models, the non-core parameters from the metapelite melt model were considered to be potentially subject to variation in MCTC, namely the interaction energies $W_{[\mathrm{silL}, \mathrm{foL}, \mathrm{faL}], n \mathrm{~L}}$ and the $\Delta G_{[\mathrm{silL}, \mathrm{foL}, \mathrm{faL}]}^{\mathrm{mod}}$. A finite $\Delta G_{\text {woL }}^{\mathrm{mod}}$ was also explored. 
Calibration in MCTC was carried out simultaneously on (a) the wet and dry melting curves of anorthite (the experiments of Goldsmith (1980); Yoder (1976) and Stewart (1967), constraining the woL-silL and woL-silL-h2oL compositional joins of the melt model), (b) the inferred position of the $\mathrm{hb}+\mathrm{di}+\mathrm{opx}+\mathrm{an}+\mathrm{q}+\mathrm{L}+\mathrm{H}_{2} \mathrm{O}$ invariant point in the CMASH system, from Ellis \& Thompson (1986), (c) two reported melt compositions at large melt fraction, from the TTG-genesis studies of Patiño Douce \& Beard (1995, SQA composition) and Beard \& Lofgren (1991, Sample 478), and (d) nine estimates of phase boundary positions $\left(\mathrm{H}_{2} \mathrm{O}\right.$-out, orthopyroxene-out, hornblende-out, melt-out, quartz-out, plagioclase-out) in the same two experimental bulk compositions. The studies of Patiño Douce \& Beard (1995) and Beard \& Lofgren (1991) were chosen because the experiments represent a comprehensive $P-T$ grid for $P \leq 12.5$ kbar. The results of the calibration are shown below.

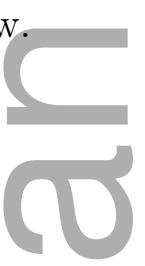

\section{CALCULATIONS ON EXPERIMENTAL COMPOSITIONS}

Figures 3 and 4 present pseudosections calculated for hydrate-breakdown melting using bulk compositions SQA (Patiño Douce \& Beard, 1995) and Sample 478 (Beard \& Lofgren, 1991, hereafter BL478). Bulk composition is treated as constant for experiments on one starting material in one type of apparatus.

\section{Experiments of Patiño Douce \& Beard (1995)}

The experiments of Patiño Douce \& Beard (1995) on SQA, a synthetic quartz amphibolite, yielded assemblages of $\mathrm{q}+\mathrm{pl}+\mathrm{ilm} / \mathrm{ru} \pm \mathrm{hb} \pm \mathrm{opx} \pm \mathrm{g} \pm \mathrm{cpx}$. Experiments at $>6 \mathrm{kbar}$ were performed in a piston cylinder and experiments at $<6 \mathrm{kbar}$ in an internally heated pressure vessel (IHPV). In Fig. 3a, calculations at $>6 \mathrm{kbar}$ used a value of $M_{\mathrm{O}}$ that gave 
$X_{\mathrm{Fe}^{3+}}=0.1$, while calculations $<6$ kbar took place with $X_{\mathrm{Fe}^{3+}}=0.25$. These values reflect the more oxidising environment of the IHPV relative to the piston cylinder, and were chosen because they span a range of $X_{\mathrm{Fe}^{3+}}$ values inferred from modelling of natural amphibolites and granulites (see Table 1), although they may not correspond closely to the unknown $X_{\mathrm{Fe}^{3+}}$ values developed in the experimental apparatus. For each of the two bulk compositions, calculated values of $\mathrm{fO}_{2}$ fall within the ranges estimated in the experiments, but this does not sensitively constrain appropriate values for $M_{\mathrm{O}}$. A single estimate for $M_{\mathrm{H}_{2} \mathrm{O}}$ was applied to both high- and low-pressure calculations, obtained by Patiño Douce \& Beard (1995) through electron probe analysis of the melted starting mixture. In reality, the starting material likely underwent substantial reduction or oxidation in each of the two assemblies, mediated by infiltration or loss of hydrogen and associated with changes in $M_{\mathrm{O}}$ and $M_{\mathrm{H}_{2} \mathrm{O}}$. However, we did not attempt to simulate the relationship between $M_{\mathrm{H}_{2} \mathrm{O}}$ in the high-pressure, low- $M_{\mathrm{O}}$ experiments versus the low-pressure, high- $M_{\mathrm{O}}$ experiments, given that the initial value of $X_{\mathrm{Fe}^{3+}}$ in the starting material is unknown.

The calculations successfully reproduce the major assemblage changes of the amphibolite-granulite transition as characterised by the experiments, specifically through the up-temperature appearance of orthopyroxene and exhaustion of hornblende (summarised in Fig. 3b). The hornblende-out boundary is well defined by the experiments, and the calculations match this constraint reasonably well, although they predict a shallower $\mathrm{d} P / \mathrm{d} T$ slope for the boundary than the experiments suggest. For the chosen values of $M_{\mathrm{O}}$ and $M_{\mathrm{H}_{2} \mathrm{O}}$, the calculations progressively underestimate the temperature of hornblende exhaustion towards lower pressure. Garnet appears up to 0.6 kbar below the minimum pressure permitted by the experiments, and at the highest pressures the orthopyroxene-in boundary moves rapidly towards excessive temperatures. In the experiments at $840^{\circ} \mathrm{C}$ and at $875^{\circ} \mathrm{C}, 10 \mathrm{kbar}$, the experimental assemblage is $\mathrm{hb}+\mathrm{pl}+\mathrm{q}+$ Fe-Ti oxides, while the calculations additionally contain aug $+\mathrm{L} \pm \mathrm{opx} \pm \mathrm{g}$. The experimental assemblage is unchanged from that of the starting materials, so an approach 
to the stable equilibrium assemblage cannot be demonstrated. Despite the moderate temperatures and very long run durations of 1-2 weeks, the shortage of vapour or a detectable volume of melt may inhibit equilibration, and it is likely that stable assemblages at these conditions do indeed include clinopyroxene \pm orthopyroxene \pm melt.

Figure 3c shows the effect of oxidation state on the calculated assemblages at $P=7$ kbar, over a range of $0<M_{\mathrm{O}}<1.62 \mathrm{~mole} \%\left(0<X_{\mathrm{Fe}^{3+}}<0.50\right)$. Under the relatively reduced conditions assumed for the piston cylinder assembly, the temperature of the hornblende-out boundary in particular is a strong function of $M_{\mathrm{O}}$, rising from $830^{\circ} \mathrm{C}$ to $905^{\circ} \mathrm{C}$ over the range $0<M_{\mathrm{O}}<0.5$ mole $\%\left(0<X_{\mathrm{Fe}^{3+}}<0.15\right)$, although further increase in $M_{\mathrm{O}}$ to $1.62 \mathrm{~mole} \%$ raises the hornblende-out temperature by only $40^{\circ} \mathrm{C}$. The sensitivity of the boundary under low- $M_{\mathrm{O}}$ conditions demonstrates the difficulties of extracting calibration information from even the best devised and most careful experimental study, and also highlights the sensitivity of future forward-modelling results to the assumed bulk O content. This sensitivity should always be quantitatively investigated via $T-M_{\mathrm{O}}$ and $P-M_{\mathrm{O}}$ plots (e.g. White et al., 2000; Diener \& Powell, 2010; Korhonen et al., 2012).

The equivalent analysis for $M_{\mathrm{H}_{2} \mathrm{O}}$ at $7 \mathrm{kbar}$ is shown in Fig. 3d. At $M_{\mathrm{H}_{2} \mathrm{O}}=4.6 \mathrm{~mol} \%$, the value used in Fig. 3a, the calculations predict a $\mathrm{H}_{2} \mathrm{O}$-present solidus at $665^{\circ} \mathrm{C}$, leading to a volumetric melt fraction of 0.33 at $900^{\circ} \mathrm{C}$ (Fig. 3e). By contrast, the experiments are thought to represent hydrate-breakdown melting and produce only modest melt fractions at $900^{\circ} \mathrm{C}$. However, by reducing the estimate of $M_{\mathrm{H}_{2} \mathrm{O}}$ in Fig. 3a from 4.6 mole $\%$ to 3.0 mole\%, a fluid-absent solidus could be calculated at $800^{\circ} \mathrm{C}$ without significantly degrading the fit to the experimental hornblende-out boundary, the latter being only a weak function of $M_{\mathrm{H}_{2} \mathrm{O}}$. A value of $M_{\mathrm{H}_{2} \mathrm{O}}=3.0$ mole $\%$ is in fact close to the estimate of bulk $\mathrm{H}_{2} \mathrm{O}$ in the starting materials based on mineral modes $\left(M_{\mathrm{H}_{2} \mathrm{O}} \sim 3.3\right.$ mole\%, Patiño Douce \& Beard, 1995). For a boundary as sensitive to bulk $\mathrm{H}_{2} \mathrm{O}$ as the water-undersaturated solidus, it is difficult to make a meaningful comparison between calculations and observations, given that the appropriate value of bulk $\mathrm{H}_{2} \mathrm{O}$ in the experimental run products is poorly known. 


\section{Experiments of Beard \& Lofgren (1991)}

Sample 478 from the study of Beard \& Lofgren (1991; BL478) is a naturally occurring low- $\mathrm{K}_{2} \mathrm{O}$ andesite, less siliceous and less potassic than the SQA material of Patiño Douce \& Beard (1995) and with higher bulk $\mathrm{FeO} /(\mathrm{FeO}+\mathrm{MgO})$. Hydrate-breakdown melting experiments, conducted in an IHPV, produced assemblages of $\mathrm{pl}+$ melt + Fe-Ti oxides \pm $\operatorname{cpx} \pm \mathrm{opx} \pm \mathrm{hb} \pm \mathrm{q}$, as shown in Fig. 4a.

Calculations on this bulk composition again describe an amphibolite to granulite facies transition that is broadly consistent with the experiments, summarised in Fig. 4b. As for the SQA composition, the calculated prediction of clinopyroxene stability conflicts with the lowest-temperature experiment at $850^{\circ} \mathrm{C}, 6.9 \mathrm{kbar}$. This experiment yielded pargasitic amphibole $+\mathrm{q}+\mathrm{pl}+\mathrm{Fe}-\mathrm{Ti}$ oxides $+6.2 \mathrm{wt} \% \mathrm{~L}$, whereas the starting assemblage was actinolitic amphibole $+\mathrm{q}+\mathrm{pl}+\mathrm{Fe}-\mathrm{Ti}$ oxides. We tentatively suggest that the small quantity of melt present in an otherwise dry experiment may again have been insufficient to allow the stable crystalline assemblage to form. If this is the case, the experiments again primarily define an upper temperature limit on the hornblende-out boundary. The calculated quartz-out boundary lies at too high a temperature, but is shown in Fig. 4c and d to be particularly sensitive to $M_{\mathrm{O}}$ and $M_{\mathrm{H}_{2} \mathrm{O}}$. At $900^{\circ} \mathrm{C}$ and $1 \mathrm{kbar}$ the calculations predict $\mathrm{H}_{2} \mathrm{O}$ as a free phase, so they are compared with the results of an $\mathrm{H}_{2} \mathrm{O}$-saturated experiment on the same starting material, but fail to reproduce the observed amphibole + quartz assemblage. This is not a significant concern, as the focus of the model calibration was on the more geologically relevant situation of hydrate-breakdown melting (Brown \& Fyfe, 1970)

The value of $M_{\mathrm{O}}$ chosen for the calculations in Fig. 4a corresponds to $X_{\mathrm{Fe}^{3+}}=0.2$, which was assumed to be plausible for the natural starting material, and consistent with exposure to the IHPV assembly over moderate run durations of around $90-120$ hours. The $T-M_{\mathrm{O}}$ plot (Fig. 4c) shows that, for the relatively oxidised conditions imposed, the calculated 7 
kbar position of the hornblende-out boundary varies only from $885^{\circ} \mathrm{C}$ at $M_{\mathrm{O}}=0.76 \mathrm{~mole} \%$ $\left(X_{\mathrm{Fe}^{3+}}=0.15\right)$ to $902^{\circ} \mathrm{C}$ at $M_{\mathrm{O}}=1.27$ mole $\%\left(X_{\mathrm{Fe}^{3+}}=0.25\right)$. The hornblende-out boundary is also almost indifferent to $M_{\mathrm{H}_{2} \mathrm{O}}$ in the range 0.5 to 4.5 mole\% (Fig. $4 \mathrm{~d}$ ). The value of $M_{\mathrm{H}_{2} \mathrm{O}}$ chosen for Fig. 4a is 3.42 mole\%, larger than the 1.72 mole\% estimated by loss on ignition from the starting materials by Beard \& Lofgren (1991). In our modelling, this choice of $M_{\mathrm{H}_{2} \mathrm{O}}$ leads to the coexistence of orthopyroxene and hornblende over a narrow $\left(\sim 50^{\circ} \mathrm{C}\right)$ temperature range, whereas for values of $M_{\mathrm{H}_{2} \mathrm{O}}<3.1 \mathrm{~mole} \%$, orthopyroxene joins the assemblage at rather low temperatures and creates a wide field of hornblende-granulite.

\section{0}

\section{Hornblende-out boundaries in various experimental studies}

Since only two bulk compositions from TTG-genesis experiments were used in the model calibration, Fig. 5 summarises the results of calculations on the hornblende-out boundary in four additional bulk compositions that were not involved in the calibration process, taken from the hydrate-breakdown melting studies of Beard \& Lofgren (1991); Rushmer (1991); Wolf \& Wyllie (1994) and Skjerlie \& Patiño Douce (1995). Comparable calculations for SQA and BL478, the compositions used in calibration, are also shown. In each case, the true temperature of the hornblende-out boundary could be inferred with some confidence from an isobaric sequence of experiments, in which the final hornblende coexisted with a moderate melt fraction and had an apparently equilibrated composition. The calculations, shown as blue bars, locate the hornblende-out boundary for each experimental phase assemblage. Where possible, calculations were performed over generous ranges of $M_{\mathrm{H}_{2} \mathrm{O}}$ (3.5-6.5 mole\%, equivalent to $\sim 1-2 \mathrm{wt} \%$ ) and $M_{\mathrm{O}}$ (such that $0.1<X_{\mathrm{Fe}^{3+}}<0.25$ ), varied simultaneously, which we expect to encompass the true experimental values in most cases. For bulk compositions WW94 and BL571, the experimental assemblage could only be calculated over a reduced range of $M_{\mathrm{O}}$ or $M_{\mathrm{H}_{2} \mathrm{O}}$; see Fig. 5 and Table 1.

The calculations generally reproduce the experimental hornblende-out temperatures 
well, although they considerably overestimate the temperature for the IAT (island arc tholeiite) composition of Rushmer (1991). Temperatures are probably underestimated for the natural amphibolite composition AGS11.1 of Skjerlie \& Patiño Douce (1995), and the calibration composition SQA. Over- or under-estimation of hornblende-out temperature may be correlated with molar bulk values of $\mathrm{Al}_{2} \mathrm{O}_{3} /\left(\mathrm{CaO}+\mathrm{Na}_{2} \mathrm{O}+\mathrm{K}_{2} \mathrm{O}\right)$, of which IAT has the highest value and AGS11.1 and SQA relatively low values.

To a considerable extent the variation of modelled boundaries with bulk composition is a function of the well established Holland \& Powell (2011) dataset calibration, combined with the superimposed $\Delta G_{\mathrm{i}}^{\text {mod }}$ and $\Delta G_{\mathrm{i}}^{\text {make }}$ terms. Therefore it is perhaps unsurprising that the results of these calculations are reasonable, even though only two of the TTG-genesis studies were incorporated into the fitting.

\section{DISCUSSION}

The newly calibrated $a-x$ relations extend the scope of phase-equilibrium forward-modelling methods to include metabasic rocks at high temperature. A pseudosection approach to thermobarometry is now feasible for such rocks, and other questions that incorporate a bulk composition constraint, such as limits on melt loss, may now be addressed. Methods of this kind have previously brought insight into metamorphic processes in metapelites (e.g. White et al., 2003; Kelsey et al., 2003; Johnson \& Brown, 2004; Halpin et al., 2007; Streule et al., 2010; Korhonen et al., 2010; Palin et al., 2012). Strictly the calibration of the $a-x$ relations described in this paper was limited to $\leq 13 \mathrm{kbar}$, owing to the lack of a thermodynamic model for aqueous fluid containing dissolved silicate material. However, it is reasonable to use the metabasite models with caution whenever the results can be compared with observations to demonstrate that appropriate stable assemblages are calculated. In the 
companion paper, Palin et al. (2016b), we examine calculations with the metabasite models on a variety of natural compositions, comparing the calculated assemblages and melt compositions with expectations drawn from observation and experiment.

Through the above comparison of phase diagram calculations with experiments, it is possible to comment on the uncertainties and limitations of the models. The models can probably be expected to give a correct sequence of up-temperature assemblages, with respect to major phases. Within the calibration range of the $a-x$ relations, phase-in/phase-out boundaries are likely to be constrained to within $50-100^{\circ} \mathrm{C}$, or $1-2 \mathrm{kbar}$ for a strongly pressure-dependent boundary, allowing for the difficulty of assessing $M_{\mathrm{O}}$ and $M_{\mathrm{H}_{2} \mathrm{O}}$ during model calibration. Comparable magnitudes of uncertainty are associated with estimating a representative bulk composition for an equilibrium assemblage in a natural rock sample (Palin et al., 2016a). As in all forward modelling of phase equilibria, careful consideration of the sensitivity of results to $M_{\mathrm{O}}$ and $M_{\mathrm{H}_{2} \mathrm{O}}$ will be essential for meaningful interpretation.

As metabasic rocks typically contain fewer phases than metapelites, fields on $P-T$ pseudosections tend to be larger, providing a less useful constraint on the pressure and temperature of mineral preservation. It may therefore be desirable to estimate $P-T$ more precisely by comparing the observed and calculated compositions of phases. An appropriate way to do this, that correctly takes account of the uncertainties in the thermodynamic modelling, is the 'average $P-T^{\prime}$ method of Powell \& Holland (1988) and Powell \& Holland (1994). This can be carried out in THERMOCALC, using the standard input files for the Holland \& Powell (2011) dataset and metabasite set of $a-x$ relations, just as for pseudosection calculations (Powell \& Holland, 2008). The average $P-T$ method finds the least-squares best estimate of $P$-at- $T$ or $T$-at- $P$ using the thermobarometric information contained in multiple independent reactions among model end-members. Starting from the activities calculated for the model end-members at the analytical phase compositions, it makes minimal uncertainty-weighted adjustments to the activities and enthalpies of the 
end-members, until the constraint is satisfied that all end-member reactions must meet at an equilibrium $P$ or $T$ (both $P$ and $T$ can be constrained using the uncertainty output). When good statistical diagnostics are obtained from the procedure, they suggest both that the analysed phases are well equilibrated, and that the thermodynamic models are sufficiently well calibrated to reflect this.

The $a_{-}-x$ relations presented in this paper should be considered only as a starting point for the modelling of high-temperature metabasic assemblages. Future $a-x$ development is expected to include a single model for clinopyroxene, replacing the current omphacite and augite models, and a single model for tonalitic-trondjhemitic to granitic melt, replacing the current metabasite and metapelite melt models. The set of metabasite $a-x$ models will be refined over time, as was the metapelite set of models before it, to correct systematic problems that emerge in calculated phase equilibria. We welcome feedback from users on the performance of the models.
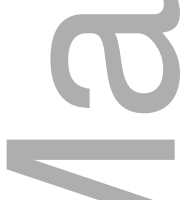

\section{ACKNOWLEDGEMENTS}

We are grateful to Sebastian Fischer for his labours in compiling an experimental database, and to Luca Ziberna for illuminating discussions about experimental methods. We thank Katy Evans, David M. Jenkins and Gary Stevens for their insightful and constructive reviews, and Mike Brown for his editorial handling. This work was supported by DFG grant WH 110/4-1 awarded to R. W. White. 


\section{REFERENCES}

Adam, J., Green, T. H. \& Day, R. A., 1992. An experimental study of two garnet pyroxenite xenoliths from the Bullenmerri and Gnotuk Maars of western Victoria, Australia. Contributions to Mineralogy and Petrology, 111, 505-514.

Asimow, P. D., Dixon, J. E. \& Langmuir, C. H., 2004. A hydrous melting and fractionation model for mid-ocean ridge basalts: application to the Mid-Atlantic Ridge near the Azores. Geochemistry, Geophysics, Geosystems, 5, Q01E16.

Auzanneau, E., Vielzeuf, D. \& Schmidt, M. W., 2006. Experimental evidence of decompression melting during exhumation of subducted continental crust. Contributions to Mineralogy and Petrology, 152, 125-148.

Beard, J. S. \& Lofgren, G. E., 1991. Dehydration melting and water-saturated melting of basaltic and andesitic greenstones and amphibolites. Journal of Petrology, 32, 365-401.

Behrens, H., 1995. Determination of water solubilities in high-viscosity melts: an experimental study on $\mathrm{NaAlSi}_{3} \mathrm{O}_{8}$ melts. European Journal of Mineralogy, 7, 905-920.

Berman, R. G., 1988. Internally-consistent thermodynamic data for minerals in the system $\mathrm{Na}_{2} \mathrm{O}-\mathrm{K}_{2} \mathrm{O}-\mathrm{CaO}-\mathrm{MgO}-\mathrm{FeO}-\mathrm{Fe}_{2} \mathrm{O}_{3}-\mathrm{Al}_{2} \mathrm{O}_{3}-\mathrm{SiO}_{2}-\mathrm{TiO}_{2}-\mathrm{H}_{2} \mathrm{O}-\mathrm{CO}_{2}$. Journal of Petrology, 29, 445-522.

Besmann, T.M. \& Spear, K. E., 2002. Thermochemical modeling of oxide glasses. Journal of the American Ceramic Society, 85, 2887-2894.

Bonnell, D. W. \& Hastie, J. W., 1985. A predictive thermodynamic model for complex high-temperature solution phases II. High Temperature Science, 26, 313-334.

Boyd, F. R. \& England, J. L., 1963. The effect of pressure on the melting of diopside, $\mathrm{CaMgSi}_{2} \mathrm{O}_{6}$, and albite, $\mathrm{NaAlSi}_{3} \mathrm{O}_{8}$, in the range up to 50 kilobars. Journal of Geophysical Research, 68, 311-323. 
Brey, G. \& Huth, J., 1984. The enstatite-diopside solvus to 60 kbar. Proceedings of the Third International Kimberlite Conference, 2, 257-264.

Brooker, R., Holloway, J. R. \& Hervig, R., 1998. Reduction in piston-cylinder experiments: the detection of carbon infiltration into platinum capsules. American Mineralogist, 83, 985-994.

Brown, G. C. \& Fyfe, W. S., 1970. The production of granitic melts during ultrametamorphism. Contributions to Mineralogy and Petrology, 28, 310-318.

Carlson, W.P. \& Lindsley, D. H., 1988. Thermochemistry of pyroxenes on the join $\mathrm{Mg}_{2} \mathrm{Si}_{2} \mathrm{O}_{6}-\mathrm{CaMgSi}_{2} \mathrm{O}_{6}$. American Mineralogist, 73, 242-252.

Chatterjee, N. D., Krüger, R., Haller, G. \& Olbricht, W., 1998. The Bayesian approach to an internally consistent thermodynamic database: theory, database, and generation of phase diagrams. Contributions to Mineralogy and Petrology, 133, 149-168.

Chu, X. \& Ague, J. J., 2013. Phase equilibria for graphitic metapelite including solution of $\mathrm{CO}_{2}$ in melt and cordierite: implications for dehydration, partial melting and graphite precipitation. Journal of Metamorphic Geology, 31, 843-862.

Coggon, R. \& Holland, T. J. B., 2002. Mixing properties of phengitic micas and revised garnet-phengite thermobarometers. Journal of Metamorphic Geology, 20, 683-696.

De Paoli, M. C., 2006. Cretaceous high-P granulite and high-T eclogite metamorphism at Breaksea Sound, SW New Zealand. PhD thesis, University of Sydney School of Geosciences.

Diener, J. F. A. \& Powell, R., 2010. Influence of ferric iron on the stability of mineral assemblages. Journal of Metamorphic Geology, 28, 599-613.

Diener, J. F. A. \& Powell, R., 2012. Revised activity-composition models for clinopyroxene and amphibole. Journal of Metamorphic Geology, 30, 131-142. 
Diener, J. F. A., Powell, R., White, R. W. \& Holland, T. J. B., 2007. A new thermodynamic model for clino- and orthoamphiboles in $\mathrm{Na}_{2} \mathrm{O}-\mathrm{CaO}-\mathrm{FeO}-\mathrm{MgO}-\mathrm{Al}_{2} \mathrm{O}_{3}-\mathrm{SiO}_{2}-\mathrm{H}_{2} \mathrm{O}-\mathrm{O}$. Journal of Metamorphic Geology, 25, 631-656.

Dolejš, D. \& Manning, C. E., 2010. Thermodynamic model for mineral solubility in aqueous fluids: theory, calibration and application to model fluid-flow systems.

Geofluids, 10, 20-40.

Droop, G. T. R., 1987. A general equation for estimating $\mathrm{Fe}^{3+}$ concentrations in ferromagnesian silicates and oxides from microprobe analyses, using stoichiometric criteria. Mineralogical Magazine, 51, 431-435.

Ellis, D. J. \& Thompson, A. B., 1986. Subsolidus and partial melting reactions in the quartz-excess $\mathrm{CaO}+\mathrm{MgO}+\mathrm{Al}_{2} \mathrm{O}_{3}+\mathrm{SiO}_{2}+\mathrm{H}_{2} \mathrm{O}$ system under water-excess and water-deficient conditions to $10 \mathrm{~kb}$ : some implications for the origin of peraluminous melts from mafic rocks. Journal of Petrology, 27, 91-121.

Foley, S. F., Buhre, S. \& Jacob, D. E., 2003. Evolution of the Archaean crust by delamination and shallow subduction. Nature, 421, 249-252.

Gerya, T. V., Maresch, W. V., Burchard, M., Zakhartchouk, V., Doltsinis, N. L. \& Fockenberg, T., 2005. Thermodynamic modeling of solubility and speciation of silica in $\mathrm{H}_{2} \mathrm{O}-\mathrm{SiO}_{2}$ fluid up to $1300^{\circ} \mathrm{C}$ and $20 \mathrm{kbar}$ based on the chain reaction formalism. European Journal of Mineralogy, 17, 269-283.

Ghiorso, M. S. \& Sack, R. O., 1995. Chemical mass transfer in magmatic processes, IV, a revised and internally consistent thermodynamic model for the interpolation and extrapolation of liquid-solid equilibria in magmatic systems at elevated temperatures and pressures. Contributions to Mineralogy and Petrology, 119, 197-212.

Ghiorso, M. S., Hirschmann, M. M., Reiners, P. W. \& Kress, V. C., 2002. The pMELTS: A revision of MELTS for improved calculation of phase relations and major element 
partitioning related to partial melting of the mantle to $3 \mathrm{GPa}$. Geochemistry, Geophysics, Geosystems, 3, Art. No. 1030.

Goldsmith, J. R., 1980. The melting and breakdown reactions of anorthite at high pressures and temperatures. American Mineralogist, 65, 272-284.

Goldsmith, J. R. \& Jenkins, D. M., 1985. The hydrothermal melting of low and high albite. American Mineralogist, 70, 924-933.

Goldsmith, J. R. \& Peterson, J. W., 1990. Hydrothermal melting behaviour of $\mathrm{KAlSi}_{3} \mathrm{O}_{8}$ as microcline and sanidine. American Mineralogist, 75, 1362-1369.

Gottschalk, M., 1996. Internally consistent thermodynamic data for rock-forming minerals in the system $\mathrm{SiO}_{2}-\mathrm{TiO}_{2}-\mathrm{Al}_{2} \mathrm{O}_{3}-\mathrm{Fe}_{2} \mathrm{O}_{3}-\mathrm{CaO}-\mathrm{MgO}-\mathrm{FeO}-\mathrm{K}_{2} \mathrm{O}-\mathrm{Na}_{2} \mathrm{O}-\mathrm{H}_{2} \mathrm{O}-\mathrm{CO}_{2}$. European Journal of Mineralogy, 9, 175-223.

Grant, J. A., 2009. Thermocalc and experimental modelling of melting of pelite, Morton Pass, Wyoming. Journal of Metamorphic Geology, 27, 571-578.

Green, E. C. R., Holland, T. J. B. \& Powell, R., 2007. An order-disorder model for omphacitic pyroxenes in the system jadeite-diopside-hedenbergite-acmite, with applications to eclogitic rocks. American Mineralogist, 92, 1181-1189.

Green, E. C. R., Holland, T. J. B. \& Powell, R., 2012b. A thermodynamic model for silicate melt in $\mathrm{MgO}-\mathrm{Al}_{2} \mathrm{O}_{3}-\mathrm{SiO}_{2}$ and $\mathrm{CaO}-\mathrm{MgO}-\mathrm{Al}_{2} \mathrm{O}_{3}-\mathrm{SiO}_{2}$ to $50 \mathrm{kbar}$ and $1800{ }^{\circ} \mathrm{C}$. Journal of Metamorphic Geology, 30, 579-597.

Green, E. C. R., Holland, T. J. B., Powell, R. \& White, R. W., 2012a. Garnet and spinel lherzolite assemblages in $\mathrm{MgO}-\mathrm{Al}_{2} \mathrm{O}_{3}-\mathrm{SiO}_{2}$ and $\mathrm{CaO}-\mathrm{MgO}-\mathrm{Al}_{2} \mathrm{O}_{3}-\mathrm{SiO}_{2}$ : thermodynamic models and an experimental conflict. Journal of Metamorphic Geology, 30, 561-577.

Gualda, G. A. R., Ghiorso, M. S., Lemons, R. V. \& Carley, T. L., 2012. Rhyolite-MELTS: 
A modified calibration of MELTS optimized for silica-rich, fluid-bearing magmatic systems. Journal of Petrology, 53, 875-890.

Halpin, J. A., Clarke, G. L., White, R. W. \& Kelsey, D. E., 2007. Contrasting P-T-t paths for Neoproterozoic metamorphism in MacRobertson and Kemp Lands, east Antarctica. Journal of Metamorphic Geology, 25(6), 683-701.

Hastie, J. W., 1983. New techniques and opportunities in high-temperature mass spectrometry. Pure and Applied Chemistry, 56, 1583-1600.

Hastie, J. W. \& Bonnell, D. W., 1985. A predictive phase-equilibrium model for multi-component oxide mixtures. 2. Oxides of $\mathrm{Na}-\mathrm{K}-\mathrm{Ca}-\mathrm{Mg}-\mathrm{Al}-\mathrm{Si}$. High Temperature Science, 19, 275-306.

Holland, T. J. B. \& Powell, R., 1996a. Thermodynamics of order-disorder in minerals: I. symmetric formalism applied to minerals of fixed composition. American Mineralogist, 81, 1413-1424.

Holland, T. J. B. \& Powell, R., 1996b. Thermodynamics of order-disorder in minerals: II. symmetric formalism applied to solid solutions. American Mineralogist, 81, 1425-1437.

Holland, T. J. B. \& Powell, R., 1998. An internally consistent thermodynamic dataset for phases of petrological interest. Journal of Metamorphic Geology, 16, 309-343.

Holland, T. J. B. \& Powell, R., 2001. Calculation of phase relations involving haplogranitic melts using an internally consistent thermodynamic dataset. Journal of Petrology, 42, 673-683.

Holland, T. J. B. \& Powell, R., 2003. Activity-composition relations for phases in petrological calculations: an asymmetric multicomponent formulation. Contributions to Mineralogy and Petrology, 145, 492-501. 
Holland, T. J. B. \& Powell, R., 2006. Mineral activity-composition relations and petrological calculations involving cation equipartition in multisite minerals: a logical inconsistency. Journal of Metamorphic Geology, 24, 851-861.

Holland, T. J. B. \& Powell, R., 2011. An improved and extended internally consistent thermodynamic dataset for phases of petrological interest, involving a new equation of state for solids. Journal of Metamorphic Geology, 29, 333-383.

Holland, T. J. B., Hudson, N. F. C., Powell, R. \& Harte, B., 2013. New thermodynamic models and calculated phase equilibria in NCFMAS for basic and ultrabasic compositions through the transition zone into the uppermost lower mantle. Journal of Petrology, 54, 1901-1920.

Holtz, F., Behrens, H., Dingwell, D. B. \& Johannes, W., 1995. Water solubility in haplogranitic melts. compositional, pressure and temperature dependence. American Mineralogist, 80, 94-108.

Hunt, J. D. \& Manning, C. E., 2012. A thermodynamic model for the system $\mathrm{SiO}_{2}-\mathrm{H}_{2} \mathrm{O}$ near the upper critical end point based on quartz solubility experiments at $500-1100^{\circ} \mathrm{C}$ and 5-20 kbar. Geochimica et Cosmochimica Acta, 86, 196-213.

Jackson, I., 1976. Melting of the silica isotypes $\mathrm{SiO}_{2}, \mathrm{BeF}_{2}$ and $\mathrm{GeO}_{2}$ at elevated pressures. Physics of the Earth and Planetary Interiors, 13, 218-231.

Jakobsson, S., 2012. Oxygen fugacity control in piston-cylinder experiments. Contributions to Mineralogy and Petrology, 164, 397-406.

Jennings, E. S. \& Holland, T. J. B., 2015. A simple thermodynamic model for melting of peridotite in the system NCFMASOCr. Journal of Petrology, 56, 1-24.

Johnson, T. \& Brown, M., 2004. Quantitative constraints on metamorphism in the 
Variscides of Southern Brittany — a complementary pseudosection approach. Journal of Petrology, 45, 1237-1259.

Johnson, T. E., White, R. W. \& Powell, R., 2008. Partial melting of metagreywacke: a calculated mineral equilibria study. Journal of Metamorphic Geology, 26, 837-853.

Kelsey, D., White, R., Powell, R., Wilson, C. \& Quinn, C., 2003. New constraints on metamorphism in the Rauer Group, Prydz Bay, east Antarctica. Journal of Metamorphic Geology, 21(8), 739-759.

Kennedy, G. C.,Wasserburg, G. J., Heard, H. C. \& Newton, R. C., 1962. The upper three-phase region in the system $\mathrm{SiO}_{2}-\mathrm{H}_{2} \mathrm{O}$. American Journal of Science, 260, 501-521.

Klemme, S., Ivanic, T. J., Connolly, J. A. D. \& Harte, B., 2009. Thermodynamic modelling of Cr-bearing garnets with implications for diamond inclusions and peridotite xenoliths. Lithos, 112, Supplement 2, 986-991.

Korhonen, F. J., Powell, R. \& Stout, J. H., 2012. Stability of sapphirine + quartz in the oxidized rocks of the Wilson Lake terrane, Labrador: calculated equilibria in NCKFMASHTO. Journal of Metamorphic Geology, 30, 21-36.

Korhonen, F. J., Saito, S., Brown, M. \& Siddoway, C. S., 2010. Modeling multiple melt loss events in the evolution of an active continental margin. Lithos, 116, 230-248.

Kunz, B., Johnson, T., White, R. \& Redler, C., 2014. Partial melting of metabasic rocks in Val Strona di Omegna, Ivrea Zone, northern Italy. Lithos, 190, 1-12.

Lindsley, D., 1966. Melting relations of $\mathrm{KAlSi}_{3} \mathrm{O}_{8}$ : effect of pressure up to $40 \mathrm{~kb}$. American Mineralogist, 51, 1793-1799.

Lindsley, D., 1981. The formation of pigeonite on the join hedenbergite-ferrosilite at 11.5 kbar and 15 kbar: experiments and a solution model. American Mineralogist, 66, 1175-1182. 
Lindsley, D., 1983. Pyroxene thermometry. American Mineralogist, 68, 477-493.

Lindsley, D. \& Dixon, S., 1976. Diopside-enstatite equilibria at $850^{\circ}$ to $1400^{\circ} \mathrm{C}, 5$ to $35 \mathrm{~kb}$. American Journal of Science, 276, 1285-1301.

London, D., Morgan, G. B. \& Acosta-Vigil, A., 2012. Experimental simulations of anatexis and assimilation involving metapelite and granitic melt. Lithos, 153, 292-307.

López, S. \& Castro, A., 2001. Determination of the fluid-absent solidus and supersolidus phase relationships of MORB-derived amphibolites in the range 4-14 kbar. American Mineralogist, 86, 1396-1403.

Manning, C. E., 1994. The solubility of quartz in $\mathrm{H}_{2} \mathrm{O}$ in the lower crust and upper mantle. Geochimica et Cosmochimica Acta, 58, 4831-4839.

Manning, C. E., 2007. Solubility of corundum + kyanite in $\mathrm{H}_{2} \mathrm{O}$ at $700^{\circ}$ and $10 \mathrm{kbar}$ : evidence for $\mathrm{Al}-\mathrm{Si}$ complexing at high pressure and temperature. Geofluids, 7, 258-269.

Matjuschkin, V., Brooker, R. A., Tattitch, B., Blundy, J. D. \& Stamper, C. C., 2015. Control and monitoring of oxygen fugacity in piston cylinder experiments. Contributions to Mineralogy and Petrology, 169.

Mori, T. \& Green, D. H., 1975. Pyroxenes in the system $\mathrm{CaMgSi}_{2} \mathrm{O}_{6}-\mathrm{Mg}_{2} \mathrm{Si}_{2} \mathrm{O}_{6}$ at high pressures and temperatures. American Mineralogist, 61, 616-625.

Newton, R. C. \& Haselton, H. T., 1981. Thermodynamics of the garnet-plagioclase- $\mathrm{Al}_{2} \mathrm{SiO}_{5}$-quartz geobarometer. In: Thermodynamics of Minerals and Melts, (eds Newton, R. C., Navrotsky, A. \& Wood, B. J.), New York, pp. 131-147. Springer Verlag.

Newton, R. C. \& Manning, C. E., 2008. Thermodynamics of $\mathrm{SiO}_{2}-\mathrm{H}_{2} \mathrm{O}$ fluid near the upper critical end point from quartz solubility measurements at 10 kbar. Earth and Planetary Science Letters, 274, 241-249. 
Nickel, K. G. \& Brey, G. P., 1984. Subsolidus orthopyroxene-clinopyroxene systematics in the system $\mathrm{CaO}-\mathrm{MgO}-\mathrm{SiO}_{2}$ to $60 \mathrm{kbar}$ : a re-evaluation of the regular solution model. Contributions to Mineralogy and Petrology, 87, 35-42.

Ostrovsky, I. A., 1966. PT-diagram of the system $\mathrm{SiO}_{2}-\mathrm{H}_{2} \mathrm{O}$. Geological Journal, 5, 127-134.

Palin, R. M., Searle, M. P., Waters, D. J., Horstwood, M. S. A. \& Parrish, R. R., 2012. Combined thermobarometry and geochronology of peraluminous metapelites from the Karakorum metamorphic complex, North Pakistan; new insight into the tectonothermal evolution of the Baltoro and Hunza regions. Journal of Metamorphic Geology, 30, 793-820.

Palin, R. M.,Weller, O. M., Waters, D. J. \& Dyck, B., 2016a. Quantifying geological uncertainty in metamorphic phase equilibria modelling: a Monte Carlo assessment and implications for tectonic interpretations. Geoscience Frontiers, 7, 591-607.

Palin, R. M., White, R. W., Green, E. C. R., Diener, J. F. A., Powell, R. \& Holland, T. J. B., 2016b. High-grade metamorphism and partial melting of mafic and intermediate rocks. Journal of Metamorphic Geology, xx, xxx-xxx.

Patiño Douce, A. E. \& Beard, J. S., 1994. $\mathrm{H}_{2} \mathrm{O}$ loss from hydrous melts during fluid-absent piston cylinder experiments. American Mineralogist, 79, 585-588.

Patiño Douce, A. E. \& Beard, J. S., 1995. Dehydration-melting of amphibolite at 10 kbar: the effects of temperature and time. Journal of Petrology, 36, 707-738.

Perkins, D. \& Newton, R. C., 1980. The compositions of coexisting pyroxenes and garnet in the system $\mathrm{CaO}-\mathrm{MgO}-\mathrm{Al}_{2} \mathrm{O}_{3}-\mathrm{SiO}_{2}$ at $900^{\circ}-1,100^{\circ} \mathrm{C}$ and high pressures. Contributions to Mineralogy and Petrology, 75, 291-300. 
Pichavant, M., Mysen, B. O. \& MacDonald, R., 2002. Source and $\mathrm{H}_{2} \mathrm{O}$ content of high-MgO magmas in island arc settings: an experimental study of a primitive calc-alkaline basalt from St. Vincent, Lesser Antilles arc. Geochimica et Cosmochimica Acta, 66, 2139-2209.

Powell, R. \& Holland, T. J. B., 1988. An internally consistent dataset with uncertainties and correlations: 3. applications to geobarometry, worked examples and a computer program. Journal of Metamorphic Geology, 6, 173-204.

Powell, R. \& Holland, T. J. B., 1993. On the formulation of simple mixing models for complex phases. American Mineralogist, 78, 1174-1180.

Powell, R. \& Holland, T. J. B., 1994. Optimal geothermometry and geobarometry. American Mineralogist, 79, 120-133.

Powell, R. \& Holland, T. J. B., 1999. Relating the formulations of the thermodynamics of mineral solid solutions: activity modeling of pyroxenes, amphiboles, and micas. American Mineralogist, 84, 1-14.

Powell, R. \& Holland, T. J. B., 2008. On thermobarometry. Journal of Metamorphic Geology, 26, 155-179.

Powell, R., Holland, T. J. B. \& Worley, B., 1998. Calculating phase diagrams involving solid solutions via non-linear equations, with examples using THERMOCALC. Journal of Metamorphic Geology, 16, 577-588.

Qian, Q. \& Hermann, J., 2013. Partial melting of lower crust at 10-15 kbar: constraints on adakite and TTG formation. Contributions to Mineralogy and Petrology, 165, 1195-1224.

Rapp, R. P. \& Watson, E. B., 1995. Dehydration melting of metabasalt at 8-32 kbar: implications for continental growth and crust-mantle recycling. Journal of Petrology, 36, 891-931. 
Rapp, R. P., Watson, E. B. \& Miller, C. F., 1991. Partial melting of amphibolite/eclogite and the origin of Archean trondhjemites and tonalites. Precambrian Research, 51, 1-25.

Robinson, P., Spear, F. S., Schumacher, J. C., Laird, J., Klein, C., Evans, B. W. \& Doolan, B. J., 1982. Phase relations of metamorphic amphiboles: natural occurrence and theory. In: Reviews in Mineralogy Volume 9B: Amphiboles: Petrology and Experimental Phase Relations, (eds Veblen, D. R. \& Ribbe, P. H.), pp. 1-288. Mineralogical Society of America.

Rushmer, T., 1991. Partial melting of two amphibolites: contrasting experimental results under fluid-absent conditions. Contributions to Mineralogy and Petrology, 107, 41-59.

Schumacher, J. C., 2007. Metamorphic amphiboles: composition and coexistence. In: Reviews in Mineralogy Volume 67: Amphiboles: Crystal Chemistry, Occurrence, and Health issues, (eds Hawthorne, F. C., Oberti, R., Della Ventura, G. \& Mottana, A.), pp. 359-416. Mineralogical Society of America.

Schweitzer, E., 1982. The reaction pigeonite $=$ diopside $_{\mathrm{ss}}+$ enstatite $_{\mathrm{ss}}$ at $15 \mathrm{kbar}$. American Mineralogist, 67, 54-58.

Sen, C. \& Dunn, T., 1994. Dehydration melting of a basaltic composition amphibolite at 1.5 and 2.0 GPa: implications for the origin of adakites. Contributions to Mineralogy and Petrology, 117, 394-409.

Skjerlie, K. P. \& Patiño Douce, A. E., 1995. Anatexis of interlayered amphibolite and pelite and 10 kbar: effect of diffusion of major components on phase relations and melt fraction. Contributions to Mineralogy and Petrology, 122, 62-78.

Skjerlie, K. P. \& Patiño Douce, A. E., 2002. The fluid-absent partial melting of a zoisite-bearing quartz eclogite from 1.0 to $3.2 \mathrm{GPa}$; implications for melting in thickened continental crust and for subduction-zone processes. Journal of Petrology, 43, 291-314. 
Smith, P. M. \& Asimow, P. D., 2005. Adiabat-1ph: A new public front-end to the MELTS, pMELTS and pHMELTS. Geochemistry, Geophysics, Geosystems, 6, Q02004.

Springer, W. \& Seck, H. A., 1997. Partial fusion of basic granulites at 5 to 15 kbar: implications for the origin of TTG magmas. Contributions to Mineralogy and Petrology, 127, 30-45.

Stewart, D. B., 1967. Four phase curve in the system $\mathrm{CaAl}_{2} \mathrm{Si}_{2} \mathrm{O}_{8}-\mathrm{SiO}_{2}-\mathrm{H}_{2} \mathrm{O}$. Schweizerische Mineralogische und Petrologische Mitteilungen, 47, 35-39.

Stormer, J. C., 1975. A practical two-feldspar geothermometer. American Mineralogist, 60, 667-674.

Streule, M. J., Searle, M. P., Waters, D. J. \& Horstwood, M. S. A., 2010. Metamorphism, melting, and channel flow in the Greater Himalayan Sequence and Makalu leucogranite: constraints from thermobarometry, metamorphic modeling, and U-Pb geochronology. Tectonics, 29, TC5011.

Sun, S. S. \& McDonough, W. F., 1989. Chemical and isotopic systematics of oceanic basalts: implications for mantle compositions and processes. In: Magmatism in the Ocean Basins, (eds Saunders, A. D. \& Norry, M. J.), Vol. 42, pp. 313-345. Geological Society of London.

Thompson, A. B., 1976. Mineral reactions in pelitic rocks: II. Calculation of some $\mathrm{P}-\mathrm{T}-\mathrm{X}(\mathrm{Fe}-\mathrm{Mg})$ phase relations. American Journal of Science, 276, 425-454.

Truckenbrodt, J. \& Johannes, W., 1999. $\mathrm{H}_{2} \mathrm{O}$ loss during piston-cylinder experiments. American Mineralogist, 84, 1333-1335.

Turnock, A. C. \& Lindsley, D. H., 1981. Experimental determination of pyroxene solvi for $\leq 1$ kbar at 900 and $1000^{\circ}$ C. Canadian Mineralogist, 19, 255-267.

van Laar, J. J., 1906. Sechs Vorträge über das thermodynamischer Potential, Vieweg, Brunswick. 
White, R. W., Powell, R. \& Clarke, G. L., 2002. The interpretation of reaction textures in Fe-rich metapelitic granulites of the Musgrave Block, central Australia: constraints from mineral equilibria calculations in the system

$\mathrm{K}_{2} \mathrm{O}-\mathrm{FeO}-\mathrm{MgO}-\mathrm{Al}_{2} \mathrm{O}_{3}-\mathrm{SiO}_{2}-\mathrm{H}_{2} \mathrm{O}-\mathrm{TiO}_{2}-\mathrm{Fe}_{2} \mathrm{O}_{3}$. Journal of Metamorphic Geology, 20, 41-55.

White, R.W., Powell, R. \& Clarke, G. L., 2003. Prograde metamorphic assemblage evolution during partial melting of metasedimentary rocks at low pressures: Migmatites from Mt Stafford, central Australia. Journal of Petrology, 44, 1937-1960.

White, R. W., Powell, R. \& Holland, T. J. B., 2001. Calculation of partial melting equilibria in the system $\mathrm{Na}_{2} \mathrm{O}-\mathrm{CaO}-\mathrm{K}_{2} \mathrm{O}-\mathrm{FeO}-\mathrm{MgO}-\mathrm{Al}_{2} \mathrm{O}_{3}-\mathrm{SiO}_{2}-\mathrm{H}_{2} \mathrm{O}$ (NCKFMASH). Journal of Metamorphic Geology, 19, 139-153.

White, R. W., Powell, R. \& Holland, T. J. B., 2007. Progress relating to calculation of partial melting equilibria for metapelites. Journal of Metamorphic Geology, 25, 511-527.

White, R. W., Powell, R., Holland, T. J. B. \& Worley, B. A., 2000. The effect of $\mathrm{TiO}_{2}$ and $\mathrm{Fe}_{2} \mathrm{O}_{3}$ on metapelitic assemblages at greenschist and amphibolite facies conditions: mineral equilibria calculations in the system

$\mathrm{K}_{2} \mathrm{O}-\mathrm{FeO}=\mathrm{MgO}-\mathrm{Al}_{2} \mathrm{O}_{3}-\mathrm{SiO}_{2}-\mathrm{H}_{2} \mathrm{O}-\mathrm{TiO}_{2}-\mathrm{Fe}_{2} \mathrm{O}_{3}$. Journal of Metamorphic Geology, 18, 497-511.

White, R. W., Powell, R., Holland, T. J. B., Johnson, T. E. \& Green, E. C. R., 2014. Progress relating to calculation of partial melting equilibria for metapelites. Journal of Metamorphic Geology, 25, 511-527.

White, R. W., Stevens, G. \& Johnson, T. E., 2011. Is the crucible reproducible? Reconciling melting experiments with thermodynamic calculations. Elements, 7, 241-246.

Wolf, M. B. \& Wyllie, P. J., 1994. Dehydration-melting of amphibolite at 10 kbar: the 
effects of temperature and time. Contributions to Mineralogy and Petrology, 115, 369-383.

Wood, B. J. \& Banno, S., 1973. Garnet-orthopyroxene and orthopyroxene-clinopyroxene relationships in simple and complex systems. Contributions to Mineralogy and Petrology, 42, 109-124.

Yoder, H. S., 1976. Melting of the silica isotypes $\mathrm{SiO}_{2}, \mathrm{BeF}_{2}$ and $\mathrm{GeO}_{2}$ at elevated pressures. Carnegie Institution of Washington Yearbook, 64, 82-89.

Zhang, C., Holtz, F., Koepke, J., Wolff, P. E., Ma, C. \& Bédard, J. H., 2013. Constraints from experimental melting of amphibolite on the depth of formation of garnet-rich restites, and implications for models of Early Archean crustal growth. Precambrian Research, 231, 206-217.

Ziaja, K., Foley, S. F., White, R. W. \& Buhre, S., 2014. Metamorphism and melting of picritic crust in the early Earth. Lithos, 189, 173-184.

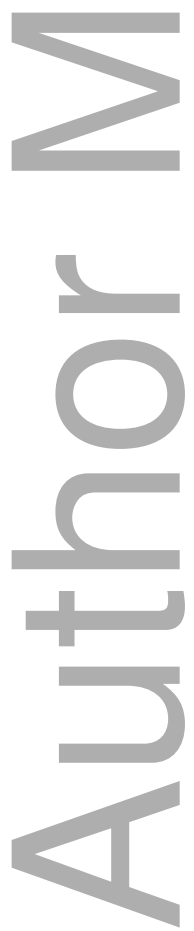




\section{APPENDIX}

The thermodynamic models discussed in this paper may be conveniently used with the software THermocalc (Powell \& Holland, 1988). The THERMOCALC software may be downloaded from the University of Mainz THERMOCALC website at http://www.metamorph.geo.uni-mainz.de/thermocalc/, along with input files containing the $a-x$ relations, versions of the Holland \& Powell (2011) dataset, and explanatory notes. THERMOCALC versions tc340 and above should be used. Versions ds62 and ds63 of the Holland \& Powell (2011) dataset have not been formally published, so anyone wishing to use them independently of THERMOCALC must extract parameters from the THERMOCALC input files. To assist in doing so, THERMOCALC may be run in mode 0 with the appropriate dataset and $a-x$ relations, generating tables of $G$ values as functions of $P$ and $T$ for each end-member, including those that do not appear explicitly in the dataset. The $G$ values include any $\Delta G_{\mathrm{i}}$ expressions applied to the end-members (identified in $a-x$ input files by the script 'DQF').

Full thermodynamic descriptions of the new $a-x$ relations for clinopyroxene (augite model), clinoamphibole and metabasite melt are given below. $\Delta G_{\mathrm{i}}$ terms are specified relative to end-members that appear in the Holland \& Powell (2011) dataset. Interaction energies $W_{\mathrm{i}, \mathrm{j}}$ and $\Delta G_{\mathrm{i}}$ parameters are specified as functions of pressure $P$ in kilobar and $T$ in kelvin: $W_{\mathrm{i}, \mathrm{j}}=W_{\mathrm{i}, \mathrm{j}}^{a}+W_{\mathrm{i}, \mathrm{j}}^{b} T+W_{\mathrm{i}, \mathrm{j}}^{c} P$ and $\Delta G_{\mathrm{i}}=\Delta G_{\mathrm{i}}^{a}+\Delta G_{\mathrm{i}}^{b} T+\Delta G_{\mathrm{i}}^{c} P$.

\section{Clinopyroxene models}

In the augite model, the following independent set of end-members is used, with the cations shown on their mixing sites, and the tetrahedral site split into T1 and T2 in order to describe $\mathrm{Si}-\mathrm{Al}$ ordering in the cats end-member (the latter is an intrinsic property of the cats end-member of the Holland \& Powell (2011) dataset, written out explicitly in the $a-x$ model): 


\begin{tabular}{lllllllllllll}
\hline & $\mathrm{M} 1$ & & & & $\mathrm{M} 2$ & & & $\mathrm{~T} 1$ & & $\mathrm{~T} 2$ \\
& $\mathrm{Mg}$ & $\mathrm{Fe}$ & $\mathrm{Al}$ & $\mathrm{Fe} 3$ & $\mathrm{Mg}$ & $\mathrm{Fe}$ & $\mathrm{Ca}$ & $\mathrm{Na}$ & $\mathrm{Si}$ & $\mathrm{Al}$ & $\mathrm{Si}$ & $\mathrm{Al}$ \\
\hline di & 1 & 0 & 0 & 0 & 0 & 0 & 1 & 0 & 1 & 0 & 1 & 0 \\
cenh & 1 & 0 & 0 & 0 & 1 & 0 & 0 & 0 & 1 & 0 & 1 & 0 \\
cfs & 0 & 1 & 0 & 0 & 0 & 1 & 0 & 0 & 1 & 0 & 1 & 0 \\
jd & 0 & 0 & 1 & 0 & 0 & 0 & 0 & 1 & 1 & 0 & 1 & 0 \\
acm & 0 & 0 & 0 & 1 & 0 & 0 & 0 & 1 & 1 & 0 & 1 & 0 \\
ocats & 0 & 0 & 1 & 0 & 0 & 0 & 1 & 0 & 1 & 0 & 0 & 1 \\
dcats & 0 & 0 & 1 & 0 & 0 & 0 & 1 & 0 & $\frac{1}{2}$ & $\frac{1}{2}$ & $\frac{1}{2}$ & $\frac{1}{2}$ \\
fmc & 1 & 0 & 0 & 0 & 0 & 1 & 0 & 0 & 1 & 0 & 1 & 0 \\
\hline
\end{tabular}

Cenh and cfs are the $C 2 / c$ polymorphs of the dataset $P b c a$ end-members en and fs, and are derived from them via $\Delta G_{\mathrm{cenh}}^{\mathrm{tran}}=G_{\mathrm{cenh}}-G_{\mathrm{en}}=3.5-0.002 T+0.048 P \mathrm{~kJ}$ and $\Delta G_{\mathrm{cfs}}^{\mathrm{tran}}=$ $G_{\mathrm{cfs}}-G_{\mathrm{fs}}=2.1-0.002 T+0.045 P \mathrm{~kJ}$. Fmc is the ordered end-member for which $G_{\mathrm{fmc}}=$ $\frac{1}{2}\left(G_{\text {cenh }}+G_{\text {cfs }}\right)+\Delta G_{\text {ordering }}$. Because $\Delta G_{\mathrm{i}}$ terms are described relative to dataset end-members, $\Delta G_{\mathrm{fmc}}^{\mathrm{od}}$ incorporates $\Delta G_{\text {ordering }}, \Delta G_{\mathrm{cenh}}^{\mathrm{tran}}$ and $\Delta G_{\mathrm{cfs}}^{\mathrm{tran}}: \Delta G_{\mathrm{fmc}}^{\mathrm{od}}=\frac{1}{2}\left(\Delta G_{\mathrm{cenh}}^{\mathrm{tran}}+\right.$ $\left.\Delta G_{\mathrm{cfs}}^{\mathrm{tran}}\right)+\Delta G_{\text {ordering }}=-1.6-0.002 T+0.0465 P \mathrm{~kJ}$. Ocats and dcats are the fully ordered and fully disordered forms respectively of the dataset cats end-member. Together they reproduce the thermodynamics of the cats end-member via prescribed values for $W_{\text {ocats,dcats }}$ and the term $\Delta G_{\text {dcats }}=3.8-0.0028816 T+0.01 P \mathrm{~kJ} . W_{\text {ocats,dcats }}, \Delta G_{\text {dcats }}^{a}$ and $\Delta G_{\text {dcats }}^{c}$ can be found in Holland \& Powell (2011), table 2c, while $\Delta G_{\text {dcats }}^{b}$ represents the configurational entropy involved in disordering. Jd and acm are subject to $\Delta G_{\mathrm{i}}^{\text {mod }}$ terms of $2 \mathrm{~kJ}$ and $-5 \mathrm{~kJ}$ respectively.

\section{Composition is described by the variables}

$$
\begin{aligned}
x & =\frac{\mathrm{Fe}}{\mathrm{Fe}+\mathrm{Mg}} \\
& =\frac{x_{\mathrm{Fe}}^{\mathrm{M} 1}+x_{\mathrm{Fe}}^{\mathrm{M} 2}}{x_{\mathrm{Fe}}^{\mathrm{M} 1}+x_{\mathrm{Fe}}^{\mathrm{M} 2}+x_{\mathrm{Mg}}^{\mathrm{M} 1}+x_{\mathrm{Mg}}^{\mathrm{M} 2}} \\
y & =x_{\mathrm{Al}}^{\mathrm{T} 1}+x_{\mathrm{Al}}^{\mathrm{T} 2} \\
f & =x_{\mathrm{Fe} 3}^{\mathrm{M} 1} \\
z & =x_{\mathrm{Ca}}^{\mathrm{M} 2} \\
j & =x_{\mathrm{Na}}^{\mathrm{M} 2},
\end{aligned}
$$


1091

and order-disorder by the parameters

$$
\begin{aligned}
Q_{f m} & =2\left(\frac{x_{\mathrm{Fe}}^{\mathrm{M} 2}}{x_{\mathrm{Fe}}^{\mathrm{Me}}+x_{\mathrm{Mg}}^{\mathrm{M} 2}}-x\right) \\
Q_{a l} & =x_{\mathrm{Al}}^{\mathrm{T} 2}-x_{\mathrm{Al}}^{\mathrm{T} 1},
\end{aligned}
$$

1092

which are found by solving the internal equilibria via which the corresponding order-disorder end-members are formed, i.e. $\mathrm{fmc}=\frac{1}{2}(\mathrm{cenh}+\mathrm{cfs})$ and dcats $=$ ocats. The site fractions are

$$
\begin{aligned}
x_{\mathrm{Mg}}^{\mathrm{M} 1} & =1-j-x-y+j x+x y+\frac{Q_{f m}}{2}(1-j-z) \\
x_{\mathrm{Fe}}^{\mathrm{M} 1} & =x-j x-x y-\frac{Q_{f m}}{2}(1-j-z) \\
x_{\mathrm{Al}}^{\mathrm{M} 1} & =j+y-f \\
x_{\mathrm{Fe} 3}^{\mathrm{M} 1} & =f \\
x_{\mathrm{Mg}}^{\mathrm{M} 2} & =1-j-x-z-\frac{Q_{f m}}{2}(1-j-z)+j x+x z \\
x_{\mathrm{Fe}}^{\mathrm{M} 2} & =x+\frac{Q_{f m}}{2}(1-j-z)-j x-x z \\
x_{\mathrm{Ca}}^{\mathrm{M} 2} & =z \\
x_{\mathrm{Na}}^{\mathrm{M} 2} & =j \\
x_{\mathrm{Si}}^{\mathrm{T} 1} & =1-\frac{1}{2}\left(y-Q_{a l}\right) \\
x_{\mathrm{Al}}^{\mathrm{T} 1} & =\frac{1}{2}\left(y-Q_{a l}\right) \\
x_{\mathrm{Si}}^{\mathrm{T} 2} & =1-\frac{1}{2}\left(y+Q_{a l}\right) \\
x_{\mathrm{Al}}^{\mathrm{T} 2} & =\frac{1}{2}\left(y+Q_{a l}\right), \\
&
\end{aligned}
$$

1094 and the ideal activities are

$$
\begin{aligned}
& a_{\mathrm{di}}^{\mathrm{ideal}}=x_{\mathrm{Mg}}^{\mathrm{M} 1} x_{\mathrm{Ca}}^{\mathrm{M} 2}\left(x_{\mathrm{Si}}^{\mathrm{T} 1} x_{\mathrm{Si}}^{\mathrm{T} 2}\right)^{\frac{1}{4}} \\
& a_{\mathrm{cenh}}^{\mathrm{ideal}}=x_{\mathrm{Mg}}^{\mathrm{M} 1} x_{\mathrm{Mg}}^{\mathrm{M} 2}\left(x_{\mathrm{Si}}^{\mathrm{T} 1} x_{\mathrm{Si}}^{\mathrm{T} 2}\right)^{\frac{1}{4}} \\
& a_{\mathrm{cfs}}^{\text {ideal }}=x_{\mathrm{Fe}}^{\mathrm{M} 1} x_{\mathrm{Fe}}^{\mathrm{M} 2}\left(x_{\mathrm{Si}}^{\mathrm{T} 1} x_{\mathrm{Si}}^{\mathrm{T} 2}\right)^{\frac{1}{4}}
\end{aligned}
$$




$$
\begin{aligned}
& a_{\text {jd }}^{\text {ideal }}=x_{\mathrm{Al}}^{\mathrm{M} 1} x_{\mathrm{Na}}^{\mathrm{M} 2}\left(x_{\mathrm{Si}}^{\mathrm{T} 1} x_{\mathrm{Si}}^{\mathrm{T} 2}\right)^{\frac{1}{4}} \\
& a_{\mathrm{acm}}^{\text {ideal }}=x_{\mathrm{Fe} 3}^{\mathrm{M} 1} x_{\mathrm{Na}}^{\mathrm{M} 2}\left(x_{\mathrm{Si}}^{\mathrm{T} 1} x_{\mathrm{Si}}^{\mathrm{T} 2}\right)^{\frac{1}{4}} \\
& a_{\text {ocats }}^{\text {ideal }}=x_{\mathrm{Al}}^{\mathrm{M} 1} x_{\mathrm{Ca}}^{\mathrm{M} 2}\left(x_{\mathrm{Si}}^{\mathrm{T} 1} x_{\mathrm{Al}}^{\mathrm{T} 2}\right)^{\frac{1}{4}} \\
& a_{\text {dcats }}^{\text {ideal }}=\sqrt{2} x_{\mathrm{Al}}^{\mathrm{M} 1} x_{\mathrm{Ca}}^{\mathrm{M} 2}\left(x_{\mathrm{Si}}^{\mathrm{T} 1} x_{\mathrm{Al}}^{\mathrm{T} 1} x_{\mathrm{Si}}^{\mathrm{T} 2} x_{\mathrm{Al}}^{\mathrm{T} 2}\right)^{\frac{1}{8}} \\
& a_{\text {fmc }}^{\text {ideal }}=x_{\mathrm{Mg}}^{\mathrm{M} 1} x_{\mathrm{Fe}}^{\mathrm{M} 2}\left(x_{\mathrm{Si}}^{\mathrm{T} 1} x_{\mathrm{Si}}^{\mathrm{T} 2}\right)^{\frac{1}{4}},
\end{aligned}
$$
099 jd acm ocats dcats

$$
\begin{aligned}
p_{\mathrm{di}} & =z-y \\
p_{\mathrm{cenh}} & =1-j-x-z-\frac{Q_{f m}}{2}(1-j-z)+j x+x z \\
p_{\mathrm{cfs}} & =\frac{Q_{f m}}{2}(1-j-z)-j x-x y \\
p_{\mathrm{jd}} & =j-f \\
p_{\mathrm{acm}} & =f \\
p_{\text {ocats }} & =Q_{a l} \\
p_{\mathrm{dcats}} & =y-Q_{a l} \\
p_{\mathrm{fmc}} & =Q_{f m}(1-j-z)+x y-x z .
\end{aligned}
$$

The interaction energies are:

\begin{tabular}{llllllll}
\hline$W_{\mathrm{i}, \mathrm{j}}(\mathrm{kJ})$ & $\mathrm{cenh}$ & $\mathrm{cfs}$ & $\mathrm{jd}$ & $\mathrm{acm}$ & ocats & dcats & fmc \\
\hline $\mathrm{di}$ & $29.8-0.03 P$ & $25.8-0.03 P$ & 26 & 21 & $12.3-0.01 P$ & $12.3-0.01 P$ & $20.6-0.03 P$ \\
cenh & & 2.3 & 50 & 62 & $45.7-0.29 P$ & $45.7-0.29 P$ & 4 \\
$\mathrm{cfs}$ & & 60 & 58 & 48 & 48 & 3.5 \\
$\mathrm{jd}$ & & & 5 & 40 & 40 & 40 \\
acm & & & & 35 & 35 & 60 \\
ocats & & & & & $3.8+0.01 P$ & 50 \\
dcats & & & & & 50 \\
\hline
\end{tabular}


with asymmetry introduced by the van Laar parameters $\alpha_{\mathrm{cenh}}=\alpha_{\mathrm{cfs}}=\alpha_{\mathrm{fmc}}=1, \alpha_{\mathrm{di}}=\alpha_{\mathrm{jd}}$ $=\alpha_{\mathrm{acm}}=1.2$, and $\alpha_{\text {ocats }}=\alpha_{\text {dcats }}=1.9$.

We reiterate that the augite model does not have a structure suitable for calculations where coexisting clinopyroxenes may be expected. To calculate two-clinopyroxene equilibria, the 'omphacite' model should be used for both phases, using appropriate starting guesses for the compositional parameters in each. The omphacite model is described in Green et al. (2007), with new $W_{\mathrm{acm}, n}$ values given in Diener \& Powell (2012) and a new value for $\Delta G_{\mathrm{acm}}^{\mathrm{mod}}$, of $-7 \mathrm{~kJ}$, given in this paper. The change to $\Delta G_{\mathrm{acm}}^{\mathrm{mod}}$ entails a corresponding change to the parameter $\Delta G_{\text {jac }}^{\text {od }}$. The jac end-member is the ordered intermediate $\mathrm{Na}_{\frac{1}{2}}^{\mathrm{M} 2} \mathrm{Na}_{\frac{1}{2}}^{\mathrm{M} 2} \mathrm{Fe}_{\frac{1}{2}}^{3+\mathrm{M} 1} \mathrm{Al}_{\frac{1}{2}}^{\mathrm{M} 1} \mathrm{Si}_{2}^{\text {tet }} \mathrm{O}_{6}$, and is formed through the reaction $\mathrm{jac}=\frac{1}{2}(\mathrm{jd}$ $+\mathrm{acm})+\Delta G_{\mathrm{jac}}^{\mathrm{od}}$, such that $\Delta G_{\mathrm{jac}}^{\mathrm{od}}=\frac{1}{2}\left(\Delta G_{\mathrm{jd}}^{\mathrm{mod}}+\Delta G_{\mathrm{acm}}^{\mathrm{mod}}\right)-1 \mathrm{~kJ}$. With $\Delta G_{\mathrm{jd}}^{\mathrm{mod}}=0$, the change to $\Delta G_{\mathrm{acm}}^{\mathrm{mod}}$ leads to $\Delta G_{\mathrm{jac}}^{\text {od }}=-4.5 \mathrm{~kJ}$, rather than the previous value of $-5 \mathrm{~kJ}$.

For comparison between the omphacite and augite models, the dependent parameters associated with the hed end-member, $\mathrm{CaFeSi}_{2} \mathrm{O}_{6}$, in the augite model are compared here with their equivalents in the omphacite model.

\begin{tabular}{lll}
\hline parameter $(\mathrm{kJ})$ & augite model & omphacite model \\
\hline$W_{\text {di,hed }}$ & 2.9 & 4 \\
$W_{\text {cenh,hed }}$ & $26.6-0.03 P$ & - \\
$W_{\text {cfs,hed }}$ & $20.9-0.03 P$ & - \\
$W_{\text {jd,hed }}$ & 42.4 & 24 \\
$W_{\text {acm,hed }}$ & 17.4 & 20.8 \\
$W_{\text {ocats,hed }}, W_{\text {dcats,hed }}$ & $8.7-0.01 P$ & - \\
$\Delta G_{\text {hed }}$ at $8 \mathrm{kbar}, 900^{\circ} \mathrm{C}$ & 1.5 & 0 \\
\hline
\end{tabular}

There is however no discordance of symmetry between the two models, as they both feature $\alpha_{\mathrm{di}}=\alpha_{\mathrm{jd}}=\alpha_{\mathrm{acm}}=\alpha_{\text {hed }}$. For the method of determining the dependency relationships, see Powell \& Holland (1999).

\section{Clinoamphibole model}

The following independent set of end-members is used, based on an amphibole formula 
${ }^{1121}$

1122

calculated for 23 oxygen atoms, with the mixing sites only shown (v=vacancy):

\begin{tabular}{llllllllllllllllllll}
\hline & $\mathrm{A}$ & & & $\mathrm{M} 13$ & \multicolumn{3}{c}{$\mathrm{M} 2$} & & \multicolumn{1}{c}{$\mathrm{M} 4$} & \multicolumn{1}{c}{$\mathrm{T} 1$} & \multicolumn{1}{c}{$\mathrm{V}$} \\
& $\mathrm{V}$ & $\mathrm{Na}$ & $\mathrm{K}$ & $\mathrm{Mg}$ & $\mathrm{Fe}$ & $\mathrm{Mg}$ & $\mathrm{Fe}$ & $\mathrm{Al}$ & $\mathrm{Fe} 3$ & $\mathrm{Ti}$ & $\mathrm{Ca}$ & $\mathrm{Mg}$ & $\mathrm{Fe}$ & $\mathrm{Na}$ & $\mathrm{Si}$ & $\mathrm{Al}$ & $\mathrm{OH}$ & $\mathrm{O}$ \\
\hline tr & 1 & 0 & 0 & 3 & 0 & 2 & 0 & 0 & 0 & 0 & 2 & 0 & 0 & 0 & 4 & 0 & 2 & 0 \\
ts & 1 & 0 & 0 & 3 & 0 & 0 & 0 & 2 & 0 & 0 & 2 & 0 & 0 & 0 & 2 & 2 & 2 & 0 \\
parg & 0 & 1 & 0 & 3 & 0 & 1 & 0 & 1 & 0 & 0 & 2 & 0 & 0 & 0 & 2 & 2 & 2 & 0 \\
gl & 1 & 0 & 0 & 3 & 0 & 0 & 0 & 2 & 0 & 0 & 0 & 0 & 0 & 2 & 4 & 0 & 2 & 0 \\
cumm & 1 & 0 & 0 & 3 & 0 & 2 & 0 & 0 & 0 & 0 & 0 & 2 & 0 & 0 & 4 & 0 & 2 & 0 \\
grun & 1 & 0 & 0 & 0 & 3 & 0 & 2 & 0 & 0 & 0 & 0 & 0 & 2 & 0 & 4 & 0 & 2 & 0 \\
a & 1 & 0 & 0 & 3 & 0 & 0 & 2 & 0 & 0 & 0 & 0 & 0 & 2 & 0 & 4 & 0 & 2 & 0 \\
b & 1 & 0 & 0 & 0 & 3 & 2 & 0 & 0 & 0 & 0 & 0 & 0 & 2 & 0 & 4 & 0 & 2 & 0 \\
mrb & 1 & 0 & 0 & 3 & 0 & 0 & 0 & 0 & 2 & 0 & 0 & 0 & 0 & 2 & 4 & 0 & 2 & 0 \\
kprg & 0 & 0 & 1 & 3 & 0 & 1 & 0 & 1 & 0 & 0 & 2 & 0 & 0 & 0 & 2 & 2 & 2 & 0 \\
tts & 1 & 0 & 0 & 3 & 0 & 0 & 0 & 0 & 0 & 2 & 2 & 0 & 0 & 0 & 2 & 2 & 0 & 2 \\
\hline
\end{tabular}

As the end-member thermodynamics are in general not well known, it is assumed that that dataset end-member tr is correct, while the other compositional end-members ts, parg, gl, cumm and grun are modified relative to this via terms $\Delta G_{\mathrm{ts}}^{\mathrm{mod}}=10 \mathrm{~kJ}, \Delta G_{\mathrm{parg}}^{\mathrm{mod}}=-10 \mathrm{~kJ}$, $\Delta G_{\mathrm{gl}}^{\mathrm{mod}}=-3 \mathrm{~kJ}, \Delta G_{\text {cumm }}^{\mathrm{mod}}=0 \mathrm{~kJ}, \Delta G_{\mathrm{grun}}^{\mathrm{mod}}=-3 \mathrm{~kJ}$. Order-disorder of Fe-Mg on the M13, $\mathrm{M} 2$ and M4 sites is governed by end-members $\mathrm{a}=\frac{3}{7}$ cumm $+\frac{4}{7}$ grun $+\Delta G_{\mathrm{a}}^{\text {od }}$ and $\mathrm{b}=\frac{2}{7}$ cumm $+\frac{5}{7}$ grun $+\Delta G_{\mathrm{b}}^{\text {od }}$, where the $\Delta G$ relative to the dataset values of the end-members are given by $\Delta G_{\mathrm{a}}^{\mathrm{od}}=\frac{3}{7} \Delta G_{\mathrm{cumm}}^{\mathrm{mod}}+\frac{4}{7} \Delta G_{\mathrm{grun}}^{\mathrm{mod}}-9.5=-11.2 \mathrm{~kJ}$ and $\Delta G_{\mathrm{b}}^{\mathrm{od}}=\frac{2}{7} \Delta G_{\mathrm{cumm}}^{\mathrm{mod}}+\frac{5}{7}$ $\Delta G_{\text {grun }}^{\text {mod }}-11.7=-13.8 \mathrm{~kJ}$. The ferric end-member mrb, and the new end-members kprg and tts, have to be 'made' from dataset end-members via the reactions $\mathrm{mrb}=\mathrm{gl}-\mathrm{gr}+\mathrm{andr}+$ $\Delta G_{\mathrm{mrb}}^{\text {make }}, \mathrm{kprg}=\mathrm{mu}-\mathrm{pa}+\mathrm{parg}+\Delta G_{\mathrm{kprg}}^{\mathrm{make}}$, and tts $=\mathrm{ts}+2 \mathrm{ru}-2 \mathrm{dsp}+\Delta G_{\mathrm{tts}}^{\mathrm{make}}$ respectively, where the $\mathrm{dG}$ terms are $\Delta G_{\mathrm{mrb}}^{\mathrm{make}}=0 \mathrm{~kJ}, \Delta G_{\mathrm{kprg}}^{\mathrm{make}}=-7.06+0.02 T \mathrm{~kJ}$ and $\Delta G_{\mathrm{tts}}^{\text {make }}=95 \mathrm{~kJ}$ (gr: grossular; andr: andradite; mu: muscovite; pa: paragonite; ru: rutile; dsp: diaspore). Diener et al. (2007) describe the structure and calibration of the core NCFMASHO model more fully.

Composition and order are described by the variables

$$
x=\frac{\mathrm{Fe}}{\mathrm{Fe}+\mathrm{Mg}}
$$




$$
\begin{aligned}
& =\frac{3 x_{\mathrm{Fe}}^{\mathrm{M} 13}+2 x_{\mathrm{Fe}}^{\mathrm{M} 2}+2 x_{\mathrm{Fe}}^{\mathrm{M} 4}}{3 x_{\mathrm{Fe}}^{\mathrm{M} 13}+2 x_{\mathrm{Fe}}^{\mathrm{M} 2}+2 x_{\mathrm{Fe}}^{\mathrm{M} 4}+3 x_{\mathrm{Mg}}^{\mathrm{M} 13}+2 x_{\mathrm{Mg}}^{\mathrm{M}}+2 x_{\mathrm{Mg}}^{\mathrm{M} 4}} \\
y & =x_{\mathrm{Al}}^{\mathrm{M} 2} \\
z & =x_{\mathrm{Na}}^{\mathrm{M} 4} \\
a & =x_{\mathrm{K}}^{\mathrm{A}}+x_{\mathrm{Na}}^{\mathrm{A}} \\
k & =\frac{x_{\mathrm{K}}^{\mathrm{A}}}{x_{\mathrm{K}}^{\mathrm{A}}+x_{\mathrm{Na}}^{\mathrm{K}}} \\
c & =x_{\mathrm{Ca}}^{\mathrm{M} 4} \\
f & =x_{\mathrm{Fe}}^{\mathrm{M} 2} \\
t & =x_{\mathrm{Ti}}^{\mathrm{M} 2} \\
Q_{1} & =x-\frac{x_{\mathrm{Fe}}^{\mathrm{M} 13}}{x_{\mathrm{Fe}}^{\mathrm{M} 13}+x_{\mathrm{Mg}}^{\mathrm{M} 13}} \\
Q_{2} & =x-\frac{x_{\mathrm{Fe}}^{\mathrm{M} 2}}{x_{\mathrm{Fe}}^{\mathrm{M} 2}+x_{\mathrm{Mg}}^{\mathrm{M} 2}} .
\end{aligned}
$$

1139 The site fractions are

$$
\begin{aligned}
x_{\mathrm{v}}^{\mathrm{A}} & =1-a \\
x_{\mathrm{Na}}^{\mathrm{A}} & =a(1-k) \\
x_{\mathrm{K}}^{\mathrm{A}} & =a k \\
x_{\mathrm{Mg}}^{\mathrm{M} 13} & =1-x+Q_{1} \\
x_{\mathrm{Fe}}^{\mathrm{M} 13} & =x-Q_{1} \\
x_{\mathrm{Mg}}^{\mathrm{M} 2} & =1-x-y-f-t+Q_{2}(1-f-t-y)+f x+t x+x y \\
x_{\mathrm{Fe}}^{\mathrm{M} 2} & =x-Q_{2}(1-f-t-y)-f x-t x-x y \\
x_{\mathrm{Al}}^{\mathrm{M} 2} & =y \\
x_{\mathrm{Fe} 3}^{\mathrm{M} 2} & =f \\
x_{\mathrm{Ti}}^{\mathrm{M} 2} & =t \\
x_{\mathrm{Ca}}^{\mathrm{M} 4} & =c \\
x_{\mathrm{Mg}}^{\mathrm{M} 4} & =1-c-x-z-\frac{3 Q_{1}}{2}-Q_{2}(1-f-t-y)+x c+x z
\end{aligned}
$$




$$
\begin{aligned}
x_{\mathrm{Fe}}^{\mathrm{M} 4} & =x+\frac{3 Q_{1}}{2}+Q_{2}(1-f-t-y)-x c-x z \\
x_{\mathrm{Na}}^{\mathrm{M} 4} & =z \\
x_{\mathrm{Si}}^{\mathrm{T} 1} & =1-\frac{1}{2}\left(f+t+y-z+\frac{1}{2} a\right) \\
x_{\mathrm{Al}}^{\mathrm{T} 1} & =\frac{1}{2}\left(f+t+y-z+\frac{1}{2} a\right) \\
x_{\mathrm{OH}}^{\mathrm{V}} & =1-t \\
x_{\mathrm{O}}^{\mathrm{V}} & =t
\end{aligned}
$$

1140 and ideal activities

$$
\begin{aligned}
a_{\mathrm{tr}}^{\text {ideal }} & =x_{\mathrm{v}}^{\mathrm{A}}\left(x_{\mathrm{Mg}}^{\mathrm{M} 13}\right)^{3}\left(x_{\mathrm{Mg}}^{\mathrm{M} 2}\right)^{2}\left(x_{\mathrm{Ca}}^{\mathrm{M} 4}\right)^{2} x_{\mathrm{Si}}^{\mathrm{T} 1}\left(x_{\mathrm{OH}}^{\mathrm{V}}\right)^{2} \\
a_{\mathrm{ts}}^{\text {ideal }} & =2 x_{\mathrm{v}}^{\mathrm{A}}\left(x_{\mathrm{Mg}}^{\mathrm{M} 13}\right)^{3}\left(x_{\mathrm{Mg}}^{\mathrm{M} 2}\right)^{2}\left(x_{\mathrm{Ca}}^{\mathrm{M} 4}\right)^{2}\left(x_{\mathrm{Si}}^{\mathrm{T} 1}\right)^{\frac{1}{2}}\left(x_{\mathrm{Al}}^{\mathrm{T} 1}\right)^{\frac{1}{2}}\left(x_{\mathrm{OH}}^{\mathrm{V}}\right)^{2} \\
a_{\mathrm{parg}}^{\text {ideal }} & =8 x_{\mathrm{Na}}^{\mathrm{A}}\left(x_{\mathrm{Mg}}^{\mathrm{M} 13}\right)^{3} x_{\mathrm{Mg}}^{\mathrm{M} 2} x_{\mathrm{Al}}^{\mathrm{M} 2}\left(x_{\mathrm{Ca}}^{\mathrm{M} 4}\right)^{2}\left(x_{\mathrm{Si}}^{\mathrm{T} 1}\right)^{\frac{1}{2}}\left(x_{\mathrm{Al}}^{\mathrm{T} 1}\right)^{\frac{1}{2}}\left(x_{\mathrm{OH}}^{\mathrm{V}}\right)^{2} \\
a_{\mathrm{gl}}^{\text {ideal }} & =x_{\mathrm{v}}^{\mathrm{A}}\left(x_{\mathrm{Mg}}^{\mathrm{M} 13}\right)^{3}\left(x_{\mathrm{Al}}^{\mathrm{M} 2}\right)^{2}\left(x_{\mathrm{Na}}^{\mathrm{M} 4}\right)^{2} x_{\mathrm{Si}}^{\mathrm{T} 1}\left(x_{\mathrm{OH}}^{\mathrm{V}}\right)^{2} \\
a_{\mathrm{cumm}}^{\text {ideal }} & =x_{\mathrm{v}}^{\mathrm{A}}\left(x_{\mathrm{Mg}}^{\mathrm{M} 13}\right)^{3}\left(x_{\mathrm{Mg}}^{\mathrm{M} 2}\right)^{2}\left(x_{\mathrm{Mg}}^{\mathrm{M} 4}\right)^{2} x_{\mathrm{Si}}^{\mathrm{T} 1}\left(x_{\mathrm{OH}}^{\mathrm{V}}\right)^{2} \\
a_{\mathrm{grun}}^{\text {ideal }} & =x_{\mathrm{v}}^{\mathrm{A}}\left(x_{\mathrm{Fe}}^{\mathrm{M} 13}\right)^{3}\left(x_{\mathrm{Fe}}^{\mathrm{M} 2}\right)^{2}\left(x_{\mathrm{Fe}}^{\mathrm{M} 4}\right)^{2} x_{\mathrm{Si}}^{\mathrm{T} 1}\left(x_{\mathrm{OH}}^{\mathrm{V}}\right)^{2} \\
a_{\mathrm{a}}^{\text {ideal }} & =x_{\mathrm{v}}^{\mathrm{A}}\left(x_{\mathrm{Mg}}^{\mathrm{M} 13}\right)^{3}\left(x_{\mathrm{Fe}}^{\mathrm{M} 2}\right)^{2}\left(x_{\mathrm{Fe}}^{\mathrm{M} 4}\right)^{2} x_{\mathrm{Si}}^{\mathrm{T} 1}\left(x_{\mathrm{OH}}^{\mathrm{V}}\right)^{2} \\
a_{\mathrm{b}}^{\text {ideal }} & =x_{\mathrm{v}}^{\mathrm{A}}\left(x_{\mathrm{Fe}}^{\mathrm{M} 13}\right)^{3}\left(x_{\mathrm{Mg}}^{\mathrm{M} 2}\right)^{2}\left(x_{\mathrm{Fe}}^{\mathrm{M} 4}\right)^{2} x_{\mathrm{Si}}^{\mathrm{T} 1}\left(x_{\mathrm{OH}}^{\mathrm{V}}\right)^{2} \\
a_{\mathrm{mrb}}^{\text {ideal }} & =x_{\mathrm{v}}^{\mathrm{A}}\left(x_{\mathrm{Mg}}^{\mathrm{M} 13}\right)^{3}\left(x_{\mathrm{Fe}}^{\mathrm{M} 2}\right)^{2}\left(x_{\mathrm{Na}}^{\mathrm{M} 4}\right)^{2} x_{\mathrm{Si}}^{\mathrm{T} 1}\left(x_{\mathrm{OH}}^{\mathrm{V}}\right)^{2} \\
a_{\mathrm{kprg}}^{\text {ideal }} & =8 x_{\mathrm{K}}^{\mathrm{A}}\left(x_{\mathrm{Mg}}^{\mathrm{M} 13}\right)^{3} x_{\mathrm{Mg}}^{\mathrm{M} 2} x_{\mathrm{Al}}^{\mathrm{M} 2}\left(x_{\mathrm{Ca}}^{\mathrm{M} 4}\right)^{2}\left(x_{\mathrm{Si}}^{\mathrm{T} 1}\right)^{\frac{1}{2}}\left(x_{\mathrm{Al}}^{\mathrm{T} 1}\right)^{\frac{1}{2}}\left(x_{\mathrm{OH}}^{\mathrm{V}}\right)^{2} \\
a_{\mathrm{tts}}^{\text {ideal }} & =2 x_{\mathrm{v}}^{\mathrm{A}}\left(x_{\mathrm{Mg}}^{\mathrm{M} 13}\right)^{3}\left(x_{\mathrm{Ti}}^{\mathrm{M} 2}\right)^{2}\left(x_{\mathrm{Ca}}^{\mathrm{M} 4}\right)^{2}\left(x_{\mathrm{Si}}^{\mathrm{T} 1}\right)^{\frac{1}{2}}\left(x_{\mathrm{Al}}^{\mathrm{T} 1}\right)^{\frac{1}{2}}\left(x_{\mathrm{O}}^{\mathrm{V}}\right)^{2},
\end{aligned}
$$

1141 with non-ideal activities given by equation (2). The end-member proportions are

$$
\begin{aligned}
p_{\mathrm{tr}} & =c+z-\frac{a}{2}-f-t-y \\
p_{\mathrm{ts}} & =y+f-z-\frac{a}{2} \\
p_{\text {parg }} & =a(1-k)
\end{aligned}
$$




$$
\begin{aligned}
p_{\mathrm{gl}} & =z-f \\
p_{\mathrm{cumm}} & =1-c-x-z-\frac{3 Q_{1}}{2}-Q_{2}(1-f-t-y)+c x+x z \\
p_{\mathrm{grun}} & =x-\frac{5 Q_{1}}{2}-2 Q_{2}(1-f-t-y)+c x-f x-t x-x y+x z \\
p_{\mathrm{a}} & =\frac{5 Q_{2}}{2}+Q_{2}(1-f-t-y)-x c-x z \\
p_{\mathrm{b}} & =\frac{3 Q_{1}}{2}+2 Q_{2}(1-f-t-y)-x c+f x+t x+x y-x z \\
p_{\mathrm{mrb}} & =f \\
p_{\mathrm{kprg}} & =a k \\
p_{\mathrm{tts}} & =t .
\end{aligned}
$$

The interaction energies are:

\begin{tabular}{lllllllllll}
\hline$W_{\mathrm{i}, \mathrm{j}}(\mathrm{kJ})$ & ts & parg & gl & cumm & grun & $\mathrm{a}$ & $\mathrm{b}$ & $\mathrm{mrb}$ & $\mathrm{kprg}$ & tts \\
\hline tr & 20 & 25 & 65 & 45 & 75 & 57 & 63 & 52 & 30 & 85 \\
ts & & -40 & 25 & 70 & 80 & 70 & 72.5 & 20 & -40 & 35 \\
parg & & 50 & 90 & 106.7 & 94.8 & 94.8 & 40 & 8 & 15 \\
gl & & & 100 & 113.5 & 100 & 111.2 & 0 & 54 & 75 \\
cumm & & & & 33 & 18 & 23 & 80 & 87 & 100 \\
grun & & & & & 12 & 8 & 91 & 96 & 65 \\
a & & & & & & 20 & 80 & 94 & 95 \\
b & & & & & & & 90 & 94 & 95 \\
mrb & & & & & & & & 50 & 50 \\
kprg & & & & & & & & & 35 \\
\hline
\end{tabular}

with asymmetry introduced by the van Laar parameters $\alpha_{\mathrm{tr}}=\alpha_{\text {cumm }}=\alpha_{\text {grun }}=\alpha_{\mathrm{a}}=\alpha_{\mathrm{b}}=$ $1, \alpha_{\mathrm{ts}}=\alpha_{\mathrm{tts}}=1.5, \alpha_{\mathrm{gl}}=\alpha_{\mathrm{mrb}}=0.8$, and $\alpha_{\mathrm{parg}}=\alpha_{\mathrm{kprg}}=1.7$

These $a-x$ relations are suitable for all of the clinoamphibole solid solutions hornblende, glaucophane, actinolite and cummingtonite, when appropriate starting guesses are given for the compositional variables.

\section{Melt model}

The end-members are mixing units with mineral-like formulae: 


\begin{tabular}{ll}
\hline end-member & formula \\
\hline qL & $\mathrm{Si}_{4} \mathrm{O}_{8}$ \\
abL & $\mathrm{NaAlSi}_{3} \mathrm{O}_{8}$ \\
kspL & $\mathrm{KAlSi}_{3} \mathrm{O}_{8}$ \\
woL & $\mathrm{CaSiO}_{3}$ \\
silL & $\mathrm{Al}_{2} \mathrm{SiO}_{5}$ \\
faL & $\mathrm{Fe}_{4} \mathrm{Si}_{2} \mathrm{O}_{8}$ \\
foL & $\mathrm{Mg}_{4} \mathrm{Si}_{2} \mathrm{O}_{8}$ \\
h2oL & $\mathrm{H}_{2} \mathrm{O}$ \\
anL & $\mathrm{CaAl}_{2} \mathrm{Si}_{2} \mathrm{O}_{8}$ \\
\hline
\end{tabular}

1152

$$
\begin{aligned}
p_{\mathrm{qL}} & =q\left(1+y_{\mathrm{anL}}\right) \\
p_{\mathrm{abL}} & =f s p n a\left(1+y_{\mathrm{anL}}\right)
\end{aligned}
$$




$$
\begin{aligned}
p_{\mathrm{kspL}} & =f_{s p}(1-n a)\left(1+y_{\mathrm{anL}}\right) \\
p_{\mathrm{woL}} & =w o\left(1+y_{\mathrm{anL}}\right)-y_{\mathrm{anL}} \\
p_{\mathrm{silL}} & =\operatorname{sil}\left(1+y_{\mathrm{anL}}\right)-y_{\mathrm{anL}} \\
p_{\mathrm{faL}} & =o l x\left(1+y_{\mathrm{anL}}\right) \\
p_{\mathrm{foL}} & =o l(1-x)\left(1+y_{\mathrm{anL}}\right) \\
p_{\mathrm{h} 2 \mathrm{LL}} & =1-(q+f s p+w o+s i l+o l)\left(1+y_{\mathrm{anL}}\right)+y_{\mathrm{anL}} \\
p_{\mathrm{anL}} & =y_{\mathrm{anL}}
\end{aligned}
$$

The ubiquitous $\left(1+y_{\mathrm{anL}}\right)$ terms arise because the reaction woL + silL $=$ anL leads to an overall change in the number of 'molecules' present, for a fixed number of atoms of liquid.

There are no site fractions in a formal sense since mixing is molecular. However it is necessary to introduce an equivalent concept in order to formulate ideal activity expressions. Considering melt as a one-phase site, the 'site fractions' are chosen to be composed of the end-member proportion expressions $p_{\mathrm{qL}}, p_{\mathrm{woL}}, p_{\mathrm{h} 2 \mathrm{oL}}, p_{\mathrm{anL}}, p_{\mathrm{ol}}=p_{\mathrm{faL}}+p_{\mathrm{foL}}$, $x_{\mathrm{ab}}=p_{\mathrm{abL}}, x_{\mathrm{ksp}}=p_{\mathrm{kspL}}$, and additionally the expressions

$$
\begin{aligned}
x_{\mathrm{Fe}} & =x \\
x_{\mathrm{Mg}} & =1-x \\
x_{\mathrm{fac}} & =1-p_{\mathrm{h} 2 \mathrm{oL}} .
\end{aligned}
$$

The ideal activities are then written as follows, with the $x_{\mathrm{Fe}}$ and $x_{\mathrm{Mg}}$ terms allowing for an extra entropic contribution from Fe-Mg mixing in addition to that of the mixing of foL and faL units, and the $x_{\text {fac }}$ term allowing for extra entropy in the addition of $\mathrm{H}_{2} \mathrm{O}$ :

$$
\begin{aligned}
a_{\mathrm{qL}}^{\text {ideal }} & =x_{\mathrm{fac}} p_{\mathrm{qL}} \\
a_{\mathrm{abL}}^{\text {ideal }} & =x_{\mathrm{fac}} x_{\mathrm{ab}} \\
a_{\mathrm{kspL}}^{\text {ideal }} & =x_{\mathrm{fac}} x_{\mathrm{ksp}}
\end{aligned}
$$




$$
\begin{aligned}
a_{\mathrm{woL}}^{\text {ideal }} & =x_{\mathrm{fac}} p_{\mathrm{woL}} \\
a_{\mathrm{silL}}^{\text {ideal }} & =x_{\mathrm{fac}} p_{\mathrm{silL}} \\
a_{\mathrm{faL}}^{\text {ideal }} & =x_{\mathrm{fac}} p_{\mathrm{ol}}\left(x_{\mathrm{Fe}}\right)^{5} \\
a_{\mathrm{foL}}^{\text {ideal }} & =x_{\mathrm{fac}} p_{\mathrm{ol}}\left(x_{\mathrm{Mg}}\right)^{5} \\
a_{\mathrm{h} 2 \mathrm{oL}}^{\text {ideal }} & =\left(p_{\mathrm{h} 2 \mathrm{oL}}\right)^{2} \\
a_{\mathrm{anL}}^{\text {ideal }} & =x_{\mathrm{fac}} p_{\mathrm{anL}} .
\end{aligned}
$$

The non-ideal activities are given by equation (1). The symmetrical interaction energies are:

\begin{tabular}{lllllllll}
\hline$W_{\mathrm{i}, \mathrm{j}}(\mathrm{kJ})$ & abL & $\mathrm{kspL}$ & woL & silL & faL & foL & h2oL & anL \\
\hline $\mathrm{qL}$ & $12-0.4 P$ & $-2-0.5 P$ & -5 & 0 & 0 & $42+1.0 P$ & $18.1-0.68 P$ & $-29.5-0.1 P$ \\
$\mathrm{abL}$ & & $-6+3.0 P$ & -12.0 & 10 & $-30+0.8 P$ & $-47.3+0.3 P$ & $-4.4-0.17 P$ & $8.6+0.4 P$ \\
$\mathrm{kspL}$ & & & -13 & 0 & -11.3 & 6.8 & $10.4-0.39 P$ & $-16-0.25 P$ \\
woL & & & & -1.6 & 6.5 & 4 & 21 & 3.5 \\
silL & & & & & 12 & 12 & $11-0.5 P$ & 6.4 \\
faL & & & & & & 18 & 29 & $-43.5-0.95 P$ \\
foL & & & & & & & $29-0.5 P$ & $-26-0.6 P$ \\
h2oL & & & & & & & & $9.75-0.5 P$ \\
\hline
\end{tabular}

In version 6.3 of the Holland \& Powell (2011) dataset, the thermodynamic properties of the h2oL end-member, incorporating the new constant-pressure heat capacity, are as follows. Enthalpy of formation $\left(\Delta_{\mathrm{f}} H\right):-281.68 \pm 0.26 \mathrm{~kJ}$, entropy $(S): 66.60 \mathrm{~kJ} \mathrm{~K}^{-1}$, volume $(V)$ : $1.363 \mathrm{~J} \mathrm{bar}^{-1}$, at 1 bar, $298 \mathrm{~K}$. Heat capacity $\left(C_{P}\right): 0.0650 \mathrm{~kJ} \mathrm{~K}{ }^{-1}$. Thermal expansivity $\left(\alpha_{0}\right): 57.80 \mathrm{~K}^{-1}$. Bulk modulus at 1 bar, $298 \mathrm{~K}$, and its first and second pressure derivatives $\left(\kappa_{0}, \kappa_{0}^{\prime}, \kappa_{0}^{\prime \prime}\right): 47.92 \mathrm{kbar}, 4.00,-0.08350 \mathrm{kbar}^{-1}$.

\section{Other models}

The $a-x$ relations for biotite, garnet and orthopyroxene were first presented in White et al. (2014). As used in White et al. (2014), the $a-x$ relations for epidote were taken from Holland \& Powell (2011), those for feldspar from Holland \& Powell (2003), and those for spinel-magnetite from White et al. (2002). For ilmenite, the Mg-bearing model used by 
1181 White et al. (2014) has been replaced, in both the metabasite set and the metapelite set, 1182 with the older model of White et al. (2000) in the system $\mathrm{FeO}-\mathrm{Fe}_{2} \mathrm{O}_{3}-\mathrm{TiO}_{2}$, as the more 1183 recent model appears to predict excessive values of $\mathrm{MgO} /(\mathrm{FeO}+\mathrm{MgO})$ in the phase.

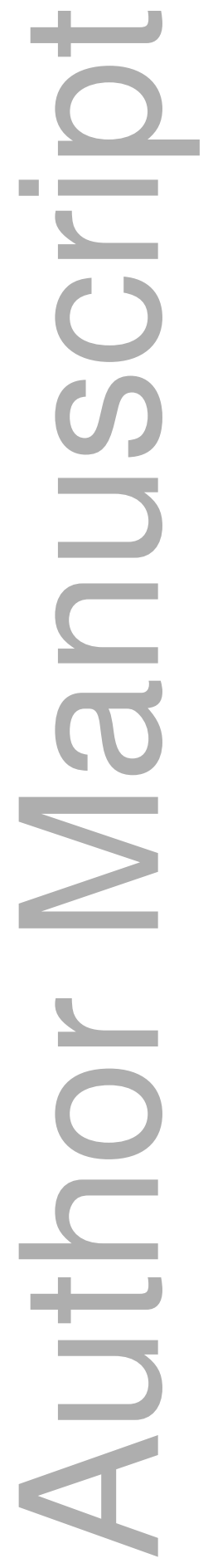




\section{FIGURE CAPTIONS}

Figure 1: Comparison of model calculations with experiments in the pyroxene quadrilateral, diopside (di) - enstatite (en) - ferrosilite (fs) - hedenbergite (hed). (a)-(d) The quadrilateral itself, displaying the data of Turnock \& Lindsley (1981) and Lindsley (1983) in black. Black arrowheads show the directions of approach to equilibrium compositions; black lines are tielines defining the miscibility gap and solvus. Grey curves and lines indicate the calculated miscibility limits; dashed grey curves show the metastable extension of the augite-pigeonite solvus within the augite orthopyroxene miscibility gap. (e)-(f) The fs-hed binary subsystem, displaying the experimental brackets of Lindsley (1981). $\mathrm{Fs}_{s s}$ and hed $\mathrm{s}_{s s}$ are solid solutions rich in the fs and hed end-members respectively.

Figure 2: Pseudosections calculated using the metabasite set of thermodynamic models for an oxidised MORB bulk composition, based on that of Sun \& McDonough (1989) but with a greater $M_{\mathrm{O}}$, giving $X_{\mathrm{Fe}^{3+}}=0.36$ (SM89, Table 1). Panels (a), (b): calculations using the augite model for clinopyroxene. Panels (c), (d): correctly modelled using the omphacite model for clinopyroxene. Where clinopyroxene is truly augitic in composition, the two models are substantially consistent, but the augite model is unable to represent moderate to high $\mathrm{Na}$ contents or the coexisting clinopyroxene phases highlighted in (b) and (d). $\mathrm{H}_{2} \mathrm{O}$ was taken to be in excess below the solidus; above the solidus values of 5.8 mole $\%$ were used for (a), (b) and 5.6 mole \% for (c), (d), such that assemblages are just $\mathrm{H}_{2} \mathrm{O}$-saturated at the solidus. Removal of $\mathrm{K}_{2} \mathrm{O}$, $\mathrm{TiO}_{2}$ from the amphibole model has negligible effect on phase boundaries. The bulk composition is the same as in Diener \& Powell (2012), fig. 1c, which was calculated with the previous generation of models.

Figure 3: Pseudosections calculated with the metabasite set for the SQA composition of Patiño Douce \& Beard (1995) (Table 1). (a) P-T pseudosection compared with 
experiments. Experimental assemblages are $\mathrm{q}+\mathrm{pl}+\mathrm{ilm} / \mathrm{ru} \pm \mathrm{hb} \pm \mathrm{opx} \pm \mathrm{cpx} \pm \mathrm{g} \pm$ L. Two different $M_{\mathrm{O}}$ values are used at higher and lower pressure, corresponding to different sets of experimental apparatus (see text). (b) Summary of (a) highlighting the implied facies transition. (c) $T-M_{\mathrm{O}}$ section at $7 \mathrm{kbar}$, representing values of $X_{\mathrm{Fe}^{3+}}$ $\leq 0.5$. (d) $T-M_{\mathrm{H}_{2} \mathrm{O}}$ sections at 7 kbar. (e) Melt fraction as a function of $T$ at $7 \mathrm{kbar}$; melt fraction is molar with phases represented on a 1-cation basis, approximating the volumetric melt fraction. Boundaries are ornamented and coloured to highlight the continuation of phase-out curves through different assemblages (colour online).

Figure 4: Pseudosections calculated with the metabasite set for sample 478 of Beard \& Lofgren (1991; BL478 in Table 1). (a) P-T pseudosection compared with experiments. Experimental assemblages are pl $+\mathrm{mt}+\mathrm{ilm} \pm \mathrm{hb} \pm \mathrm{opx} \pm \mathrm{cpx} \pm \mathrm{q}$. The experiments involved hydrate-breakdown melting except for one, marked with a square symbol, which was fluid-saturated. (b) Summary of (a) highlighting the implied facies transition. (c) $T-M_{\mathrm{O}}$ section at $7 \mathrm{kbar}$, representing values of $X_{\mathrm{Fe}^{3+}} \leq$ 0.5. (d) $T-M_{\mathrm{H}_{2} \mathrm{O}}$ sections at 7 kbar. Boundaries are ornamented and coloured to highlight the continuation of phase-out curves through different assemblages (colour online). In calculating this figure, the clinoamphibole model was used with $\Delta G_{\mathrm{gl}}^{\mathrm{mod}}=0$ $\mathrm{kJ}$, rather than the preferred value of $-3 \mathrm{~kJ}$; however this affects the position of phase field boundaries by $\leq 10^{\circ} \mathrm{C}$.

Figure 5: Interpreted temperature of the hornblende-out boundary in six experimental bulk compositions (brackets and half-brackets labelled with assemblages; bulk compositions in Table 1), compared with the temperatures obtained from calculations using a range of $M_{\mathrm{O}}$ and $M_{\mathrm{H}_{2} \mathrm{O}}$ values (blue bars, colour online). Except in the case of

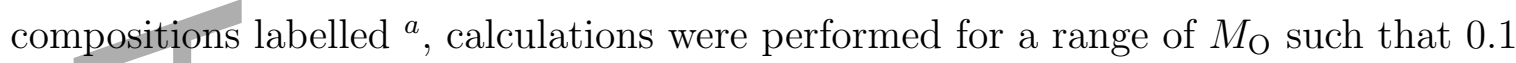
$<X_{\mathrm{Fe}^{3+}}<0.25$, and for $3.5<M_{\mathrm{H}_{2} \mathrm{O}}<6.5$ mole\% $\left(\sim 1-2 \mathrm{wt} \% \mathrm{H}_{2} \mathrm{O}\right)$, varied simultaneously. For compositions ${ }^{a}$, the blue bars represent calculations for the 
restricted range of $M_{\mathrm{O}}$ or $M_{\mathrm{H}_{2} \mathrm{O}}$ over which positive modes of phases were predicted (Table 1). For composition $\mathrm{WW} 94, \mathrm{TiO}_{2}$ was omitted as hornblende is the only Ti-bearing model involved. In compositions ${ }^{b}$, only trace hornblende was detected at the lower- $T$ end of the experimental bracket. Calculations were made on each experimental assemblage without checking that it was the most stable assemblage that the models could generate, except for compositions ${ }^{c}$, which were used in calibration. For BL478, the experimental assemblage is ambiguous, while in the calculations, stable assemblages \pm quartz are needed to cover the full range of $M_{\mathrm{O}}$ and $M_{\mathrm{H}_{2} \mathrm{O}}$.

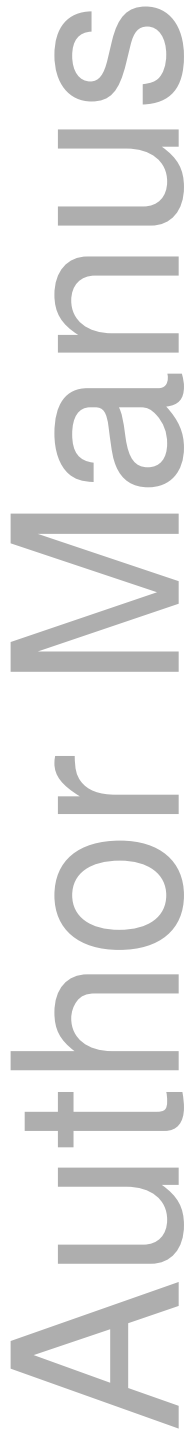


Table 1: Bulk compositions in mole \% used in calculations, expressed in terms of the chemical components used by Thermocalc. FeO ${ }^{\text {tot }}$ is total iron expressed as FeO. O, oxygen, combines only with $\mathrm{FeO}$, via the equation $2 \mathrm{FeO}+\mathrm{O}=\mathrm{Fe}_{2} \mathrm{O}_{3}$; hence $M_{\mathrm{O}}$ is identically equal to molar bulk $\mathrm{Fe}_{2} \mathrm{O}_{3}, M_{\mathrm{Fe}_{2} \mathrm{O}_{3}}$, with $X_{\mathrm{Fe}^{3+}}$ given by $2 M_{\mathrm{O}} / M_{\mathrm{FeO}}$ tot Where no value is cited in the $M_{\mathrm{H}_{2} \mathrm{O}}$ column, $\mathrm{H}_{2} \mathrm{O}$ is assumed to be in excess.

Table 2: Equilibria used in calibrating the augite model (see text), and results of calculations with the completed set of models. Observed values of compositional variables are shown in roman font, calculated values in italic. Compositional variables for the augite model are defined in the Appendix. Bulk compositions used in the calculations are given in Table 1 . Observational $f(\mathrm{aug})$ values $\left(x_{\mathrm{Fe} 3}^{\mathrm{M} 1}\right)$ obtained using the rule of Droop (1987).

Table 3: Equilibria used in calibrating the clinoamphibole model, and the results of calculations with the completed set of models (all with excess q, $\mathrm{H}_{2} \mathrm{O}$ ). Observed or other target values (see footnotes) of compositional variables are shown in roman font, calculated values in italics. Compositional variables for the clinoamphibole and augite models are defined in the Appendix. Bulk compositions used in the calculations are given in Table 1. Phase $\rightarrow 0$ indicates the zero-mode isopleth (the phase-out boundary) for phase.

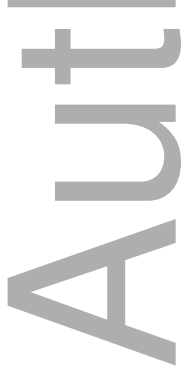



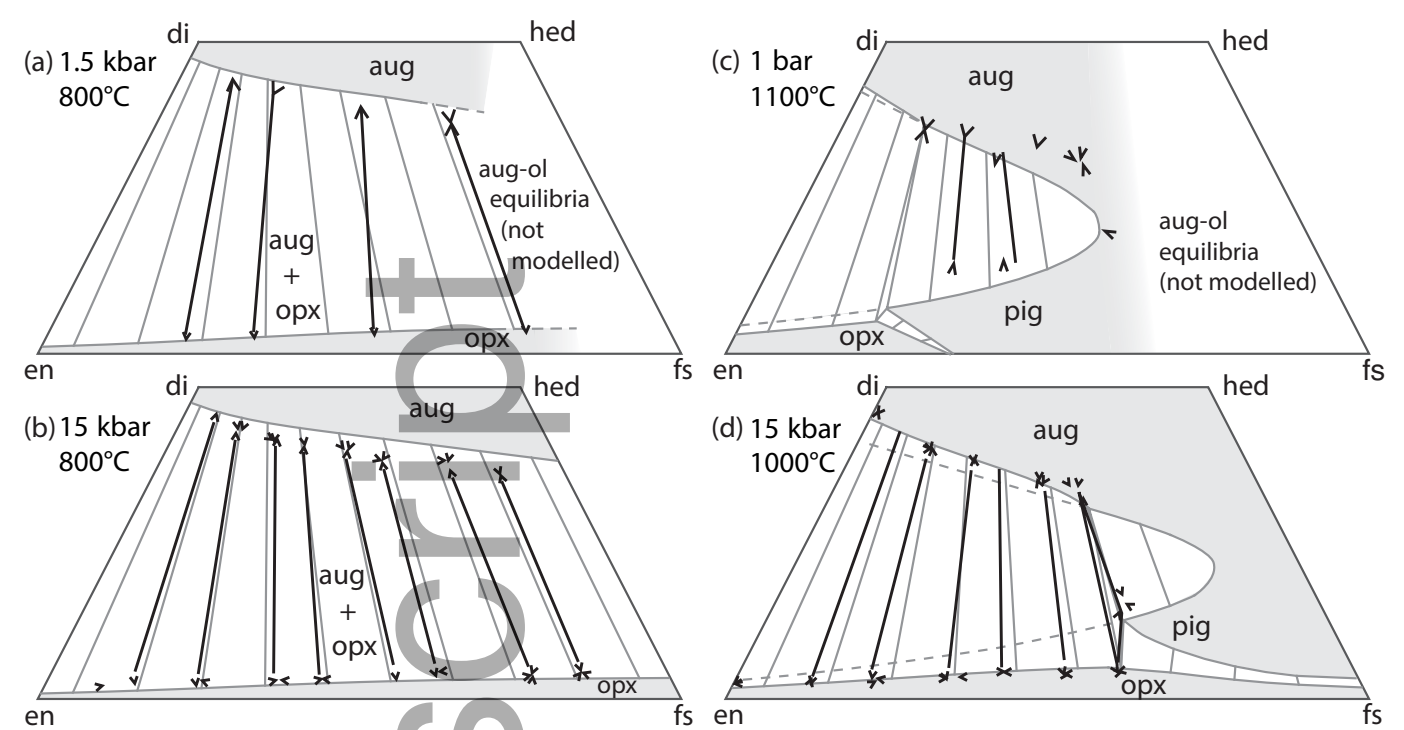

(e) 100

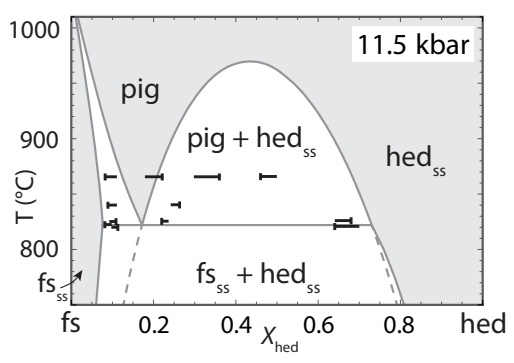

(f)

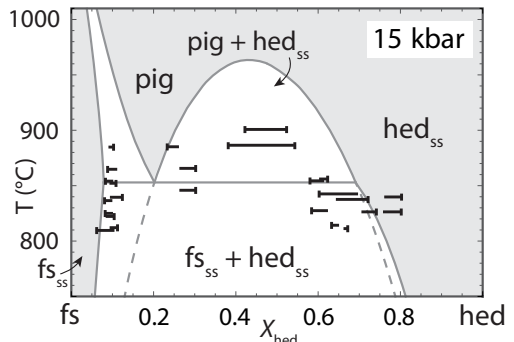

Figure 1: 
(a) NCKFMASHTO $+\mathrm{q}\left(+\mathrm{H}_{2} \mathrm{O}\right.$, subsolidus $)$

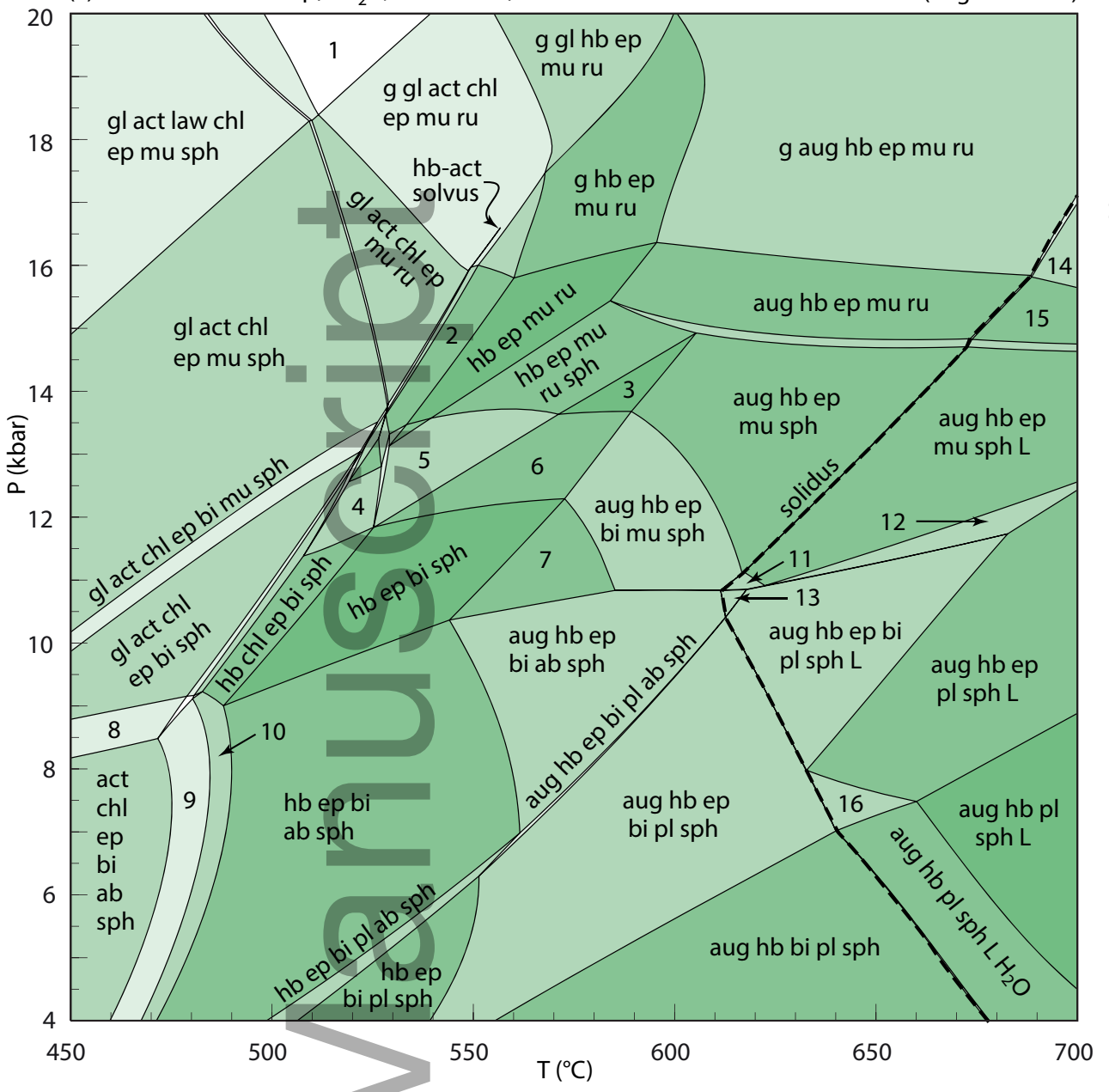

(c) NCKFMASHTO $+\mathrm{q}\left(+\mathrm{H}_{2} \mathrm{O}\right.$, subsolidus)

oxidised SM89 MORB (omphacite model)

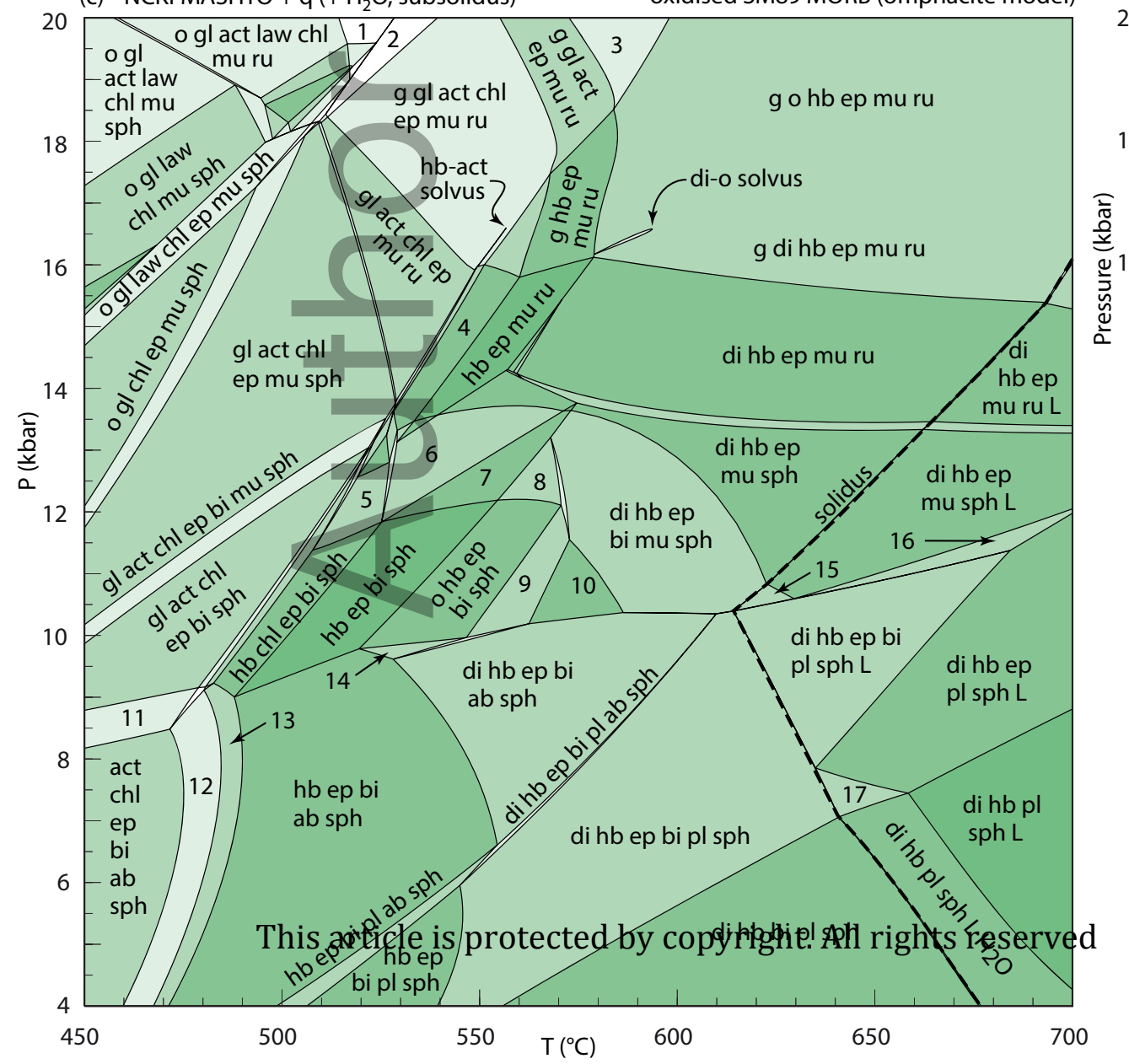

(b) contours of $j(\mathrm{cpx})=X_{\mathrm{Na}}^{\mathrm{M} 2} \quad 63$

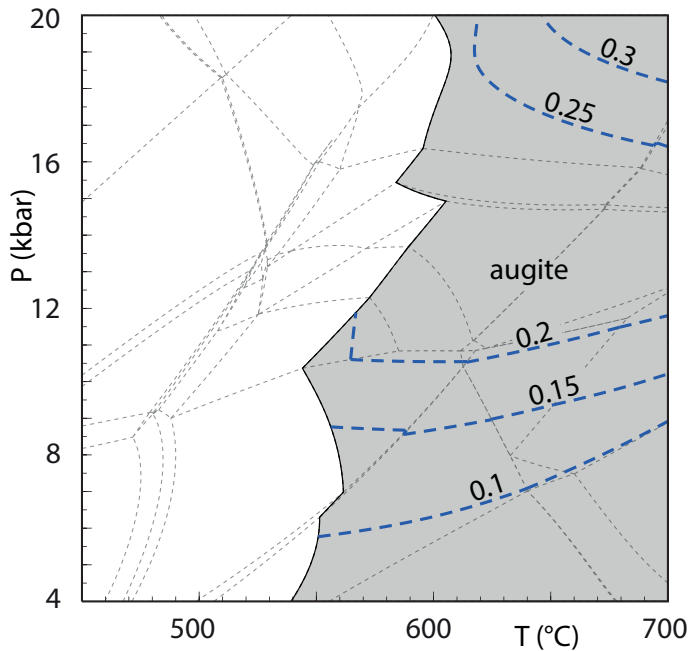

1) $\mathrm{g} \mathrm{gl} \mathrm{act} \mathrm{law} \mathrm{chl} \mathrm{ep} \mathrm{mu} \mathrm{ru}$

2) hb chl ep mu ru

3) hb ep mu sph

4) hb chl ep bi mu sph

5) hb ep mu bi ru sph

6) hb ep bi mu sph

7) aug hb ep bi sph

8) gl act chl ep bi ab sph

9) hb act chl ep bi ab sph

10) hb chl ep bi ab sph

11) aug hb ep bi mu sph $L$

12) aug hb ep mu pl sph $L$

13) aug hb ep bi ab sph $L$

14) g aug hb ep mu ru $L$

15) aug hb ep mu ru $L$

16) aug hb ep pl sph $\mathrm{L} \mathrm{H}_{2} \mathrm{O}$

(d) contours of $j(\mathrm{cpx})=X_{\mathrm{Na}}^{\mathrm{M} 2}$

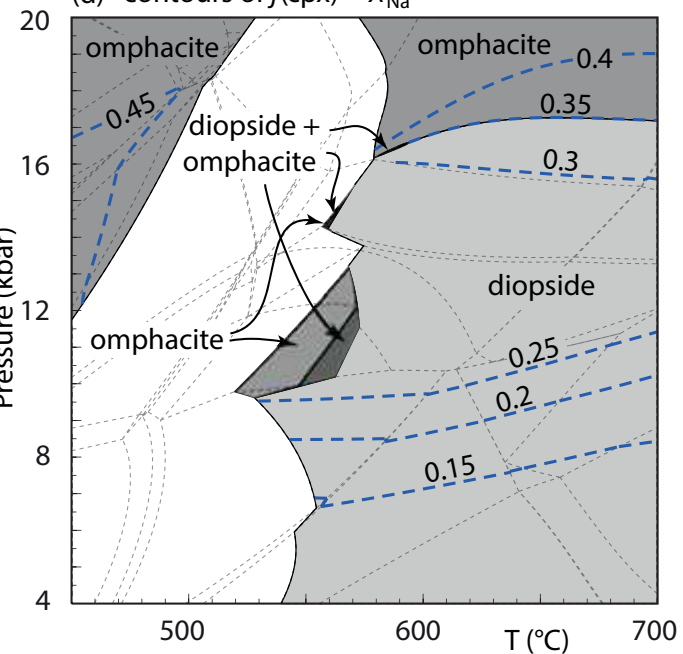

1) g o gl act law chl mu ru

2) g gl act law chl ep mu ru

3) g o gl act ep mu ru

4) hb chl ep mu ru

5) hb chl ep mu bi sph

6) hb ep mu bi ru sph

7) hb ep mu bi sph

8) o hb ep mu bi sph

9) o di hb ep bi sph

10) di hb ep bi sph

11) gl act chl ep bi ab sph

12) hb act chl ep bi ab sph

13) hb chl ep bi ab sph

14) o hb ep bi ab sph

15) di hb ep bi mu sph $L$

16) di hb ep mu pl sph $L$

17) di hb ep pl sph $L \mathrm{H}_{2} \mathrm{O}$ 


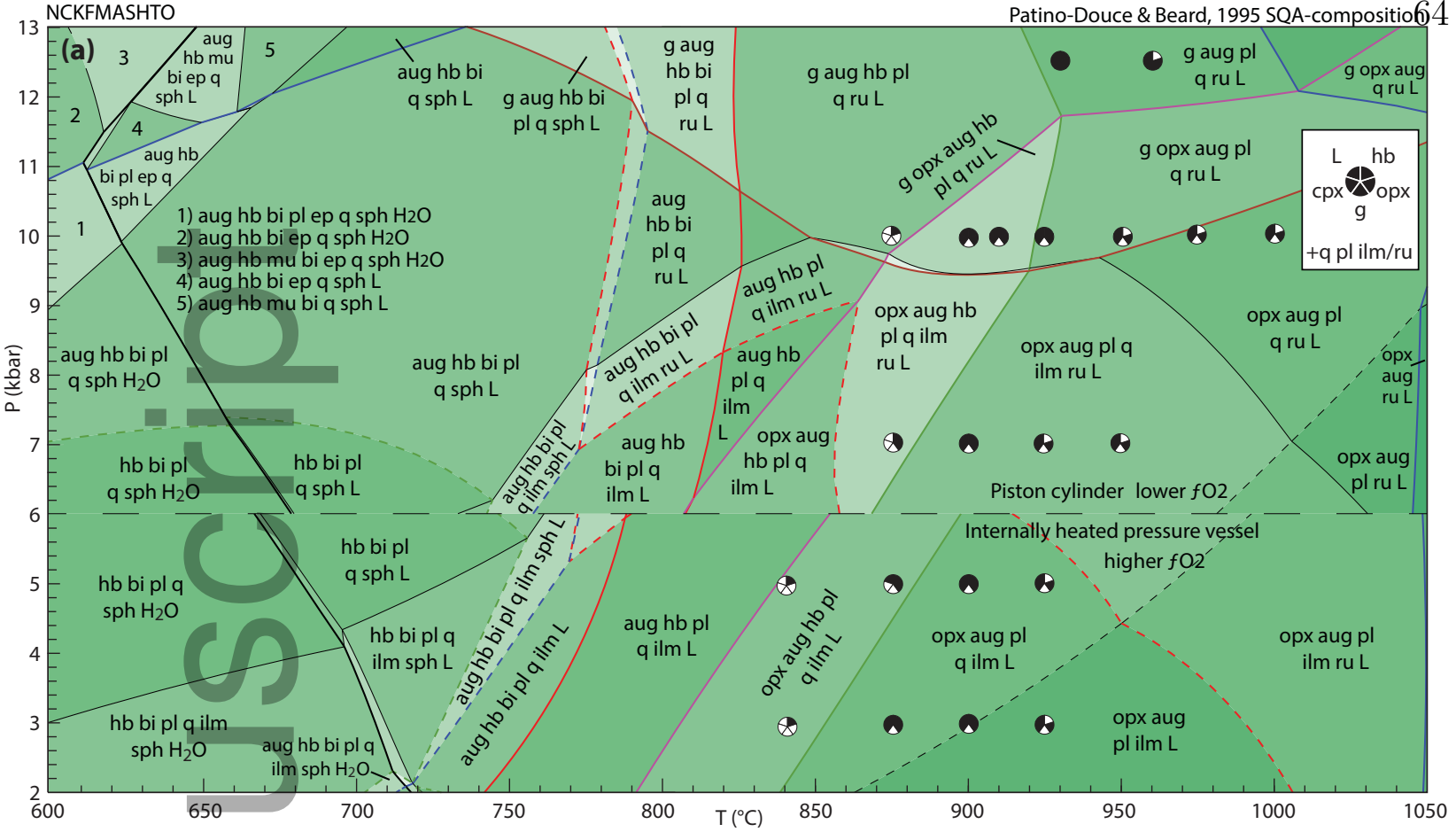

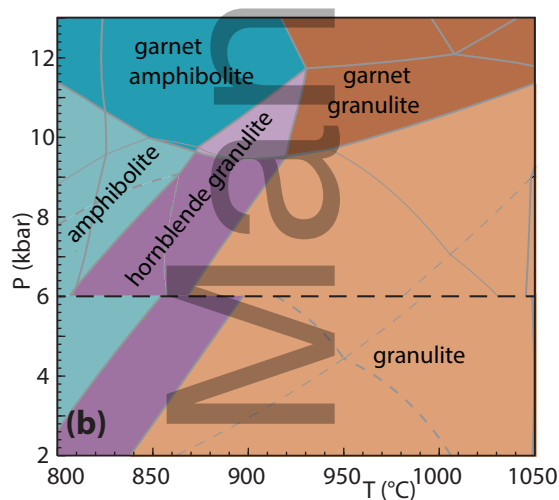

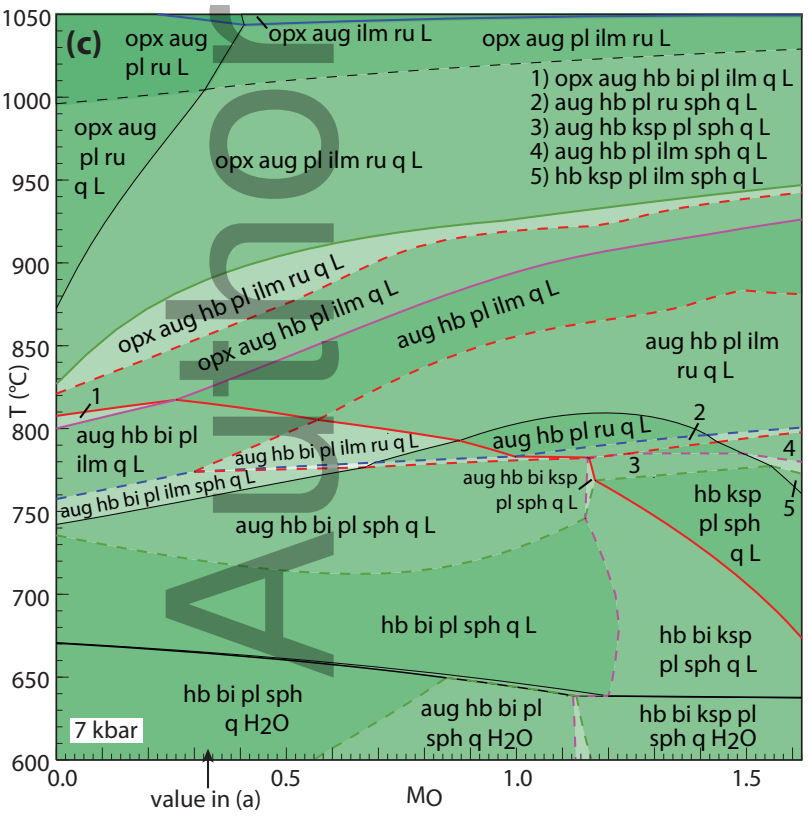

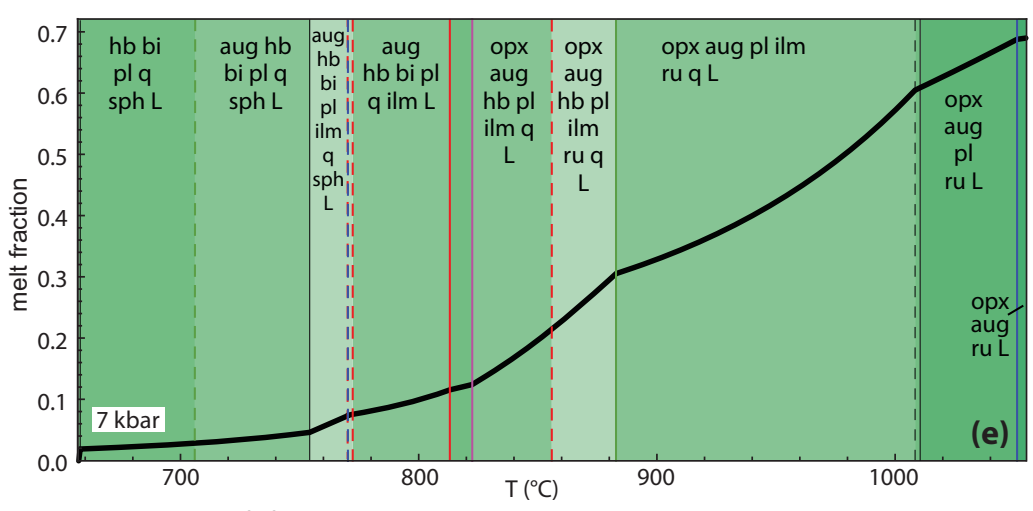

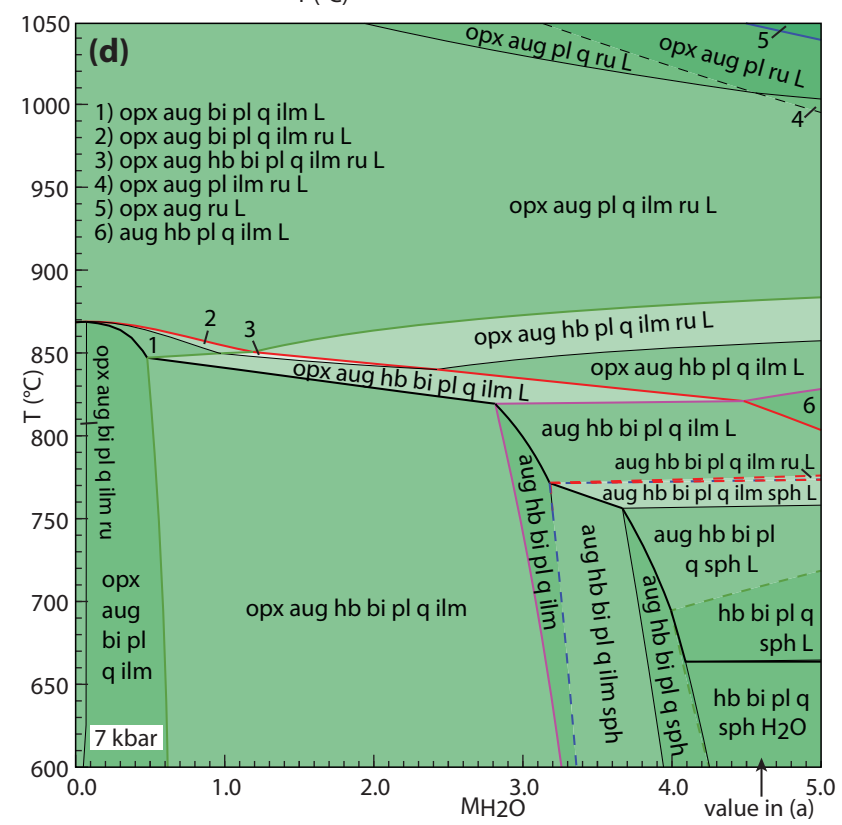

Figure 3: 

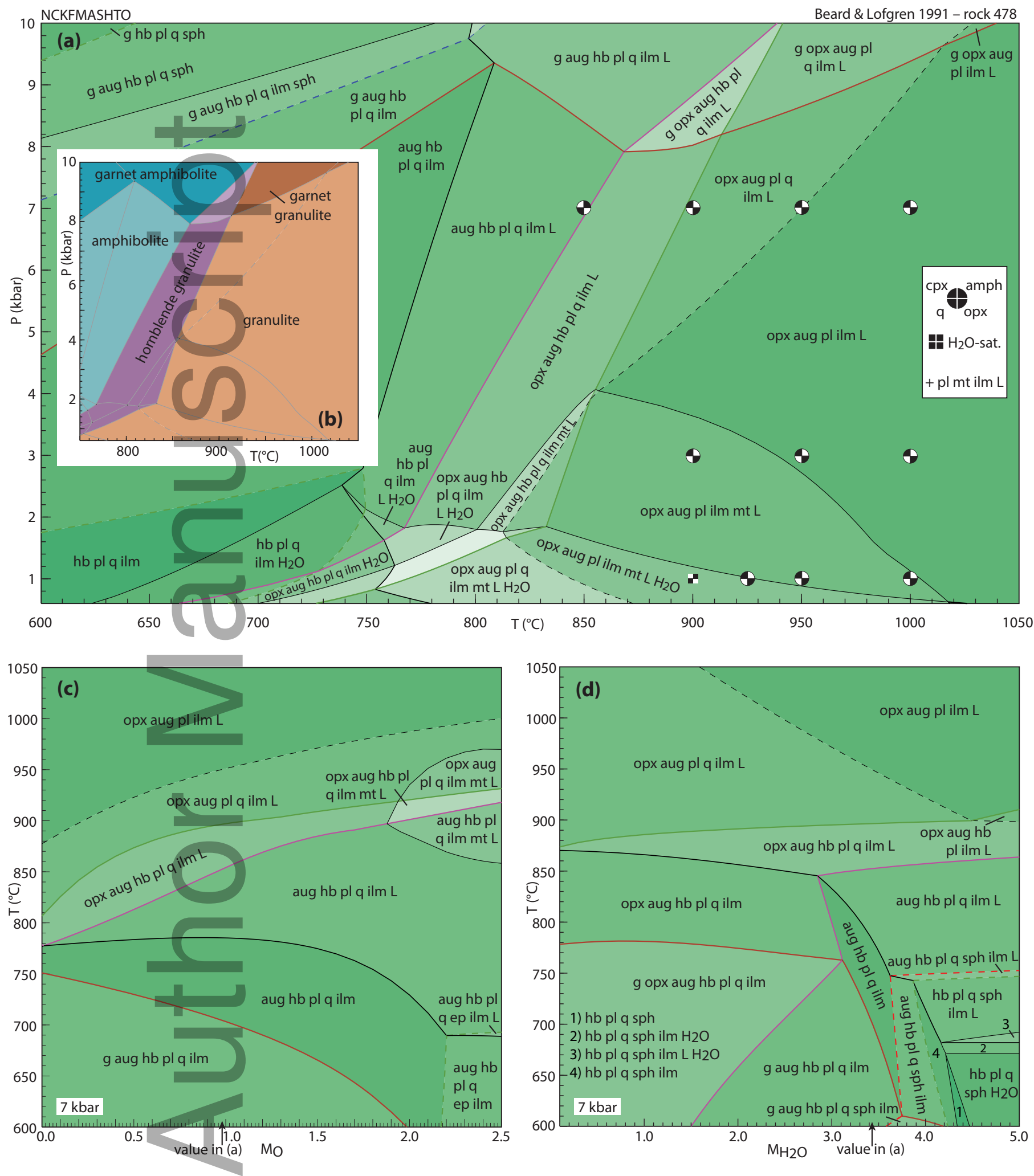

Figure 4: 


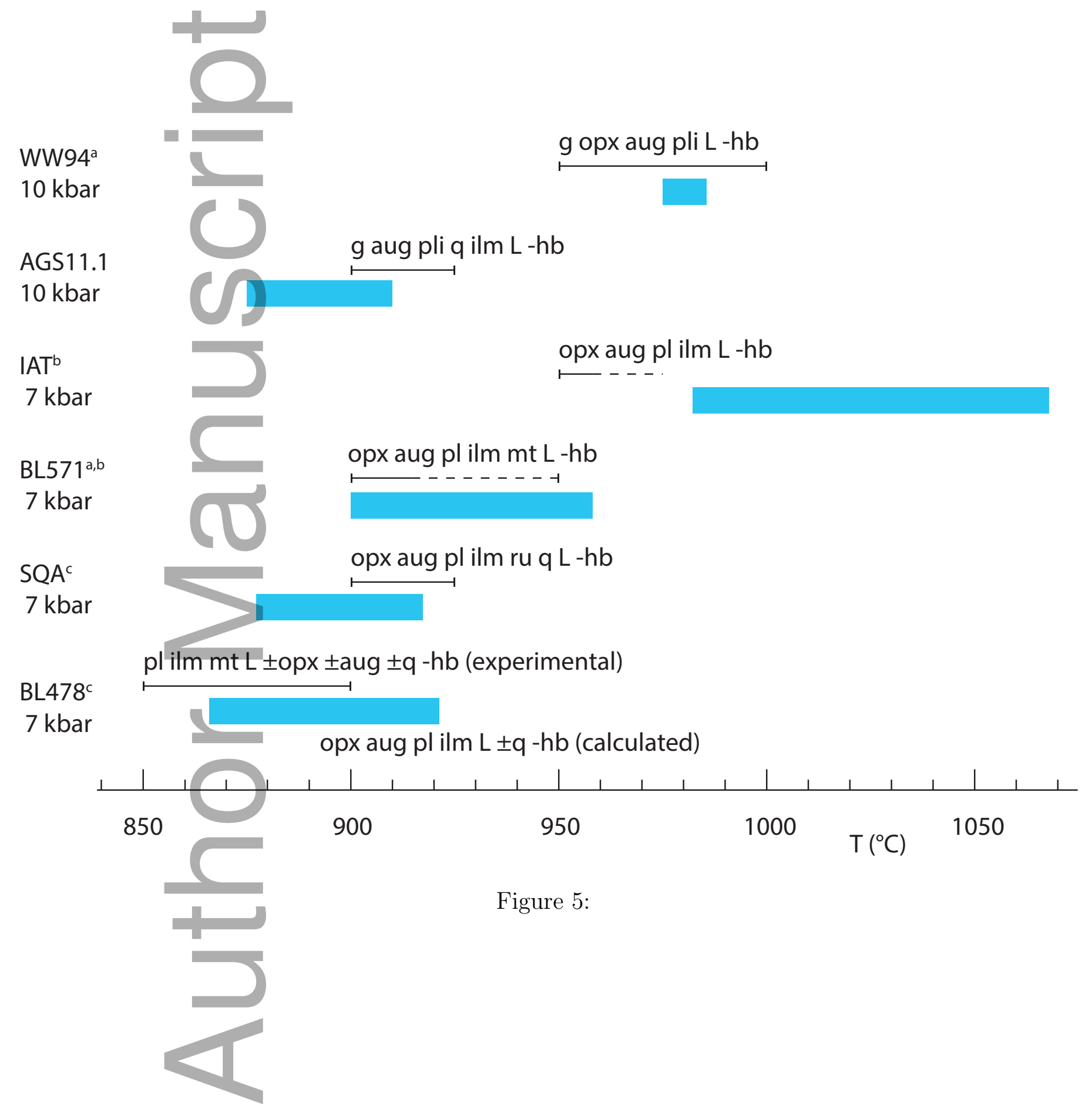

This article is protected by copyright. All rights reserved 
Table 1:

\begin{tabular}{lcrrrrrrrrr}
\hline & $M_{\mathrm{SiO}_{2}}$ & $M_{\mathrm{TiO}_{2}}$ & $M_{\mathrm{Al}_{2} \mathrm{O}_{3}}$ & $M_{\mathrm{FeO} \text { tot }}$ & $M_{\mathrm{MgO}}$ & $M_{\mathrm{CaO}}$ & $M_{\mathrm{Na}_{2} \mathrm{O}}$ & $M_{\mathrm{K}_{2} \mathrm{O}}$ & $M_{\mathrm{O}}$ & $M_{\mathrm{H}_{2} \mathrm{O}}$ \\
\hline Mcal & 55.21 & 1.01 & 8.75 & 7.84 & 12.22 & 11.75 & 2.51 & 0.22 & 0.47 & \\
SM89 & 52.47 & 1.05 & 9.10 & 8.15 & 12.71 & 12.21 & 2.61 & 0.23 & 1.47 & \\
IZ100 & 52.05 & 1.29 & 13.24 & 10.18 & 7.70 & 12.14 & 2.89 & & 0.51 & \\
dP0669 & 58.29 & 0.99 & 11.55 & 6.45 & 7.18 & 8.97 & 4.59 & 1.14 & 0.84 & \\
DR9734 & 47.05 & 0.18 & 8.77 & 5.43 & 19.02 & 17.52 & 1.39 & 0.04 & 0.60 & \\
SKA101 & 58.26 & 1.42 & 9.15 & 11.98 & 8.80 & 8.61 & 0.49 & 0.70 & 0.60 & \\
SKB116 & 53.72 & 1.75 & 9.10 & 12.40 & 7.43 & 10.85 & 2.95 & 0.42 & 1.38 & \\
PM13013 & 52.95 & 1.70 & 8.42 & 11.61 & 9.86 & 11.22 & 2.72 & 0.62 & 0.89 & \\
PM13083 & 53.24 & 0.83 & 8.62 & 9.71 & 11.32 & 12.48 & 2.41 & 0.19 & 1.19 & \\
PM13161 & 53.13 & 1.08 & 8.01 & 9.05 & 11.71 & 12.31 & 3.14 & 0.43 & 1.15 & \\
AG9 & 51.08 & 1.37 & 9.68 & 11.66 & 11.21 & 13.26 & 0.79 & 0.16 & 0.80 & \\
SQA (high-P) & 60.05 & 1.27 & 6.62 & 6.57 & 9.93 & 8.31 & 1.83 & 0.44 & 0.33 & 4.64 \\
SQA (low-P) & 59.76 & 1.26 & 6.59 & 6.54 & 9.88 & 8.27 & 1.82 & 0.44 & 0.81 & 4.62 \\
BL478 & 53.96 & 1.35 & 9.26 & 10.14 & 8.11 & 10.15 & 2.54 & 0.11 & 0.98 & 3.42 \\
WW94 & 50.09 & 0.31 & 8.91 & 7.27 & 16.50 & 15.86 & 1.00 & 0.07 & $0.35-0.86$ & $3.50-5.00$ \\
AGS11.1 & 58.31 & 0.75 & 8.62 & 10.90 & 8.44 & 11.44 & 1.14 & 0.41 & $0.52-1.30$ & $3.50-6.50$ \\
IAT & 55.99 & 0.81 & 10.41 & 6.90 & 12.12 & 10.33 & 3.24 & 0.18 & $0.33-0.82$ & $3.50-6.50$ \\
BL571 & 56.03 & 1.28 & 10.17 & 11.15 & 7.18 & 10.46 & 3.49 & 0.26 & $1.20-1.30$ & $3.50-6.50$ \\
\hline
\end{tabular}

Mcal: MORB-like composition used in calibration. SM89: oxidised average MORB composition of Sun \& McDonough (1989) (the analysed composition has $M_{\mathrm{O}}=0.5$ mole \%). IZ100: natural metabasite sample of Kunz et al. (2014), $M_{\mathrm{O}}$ estimate from pseudosection modelling. dP0669: Breaksea Orthogneiss sample 0669 (dioritic gneiss), De Paoli (2006), $M_{\mathrm{O}}$ from wet chemistry. DR9734: microprobe analysis of experimental glass, ground from a garnet pyroxenite xenolith, by Adam et al. (1992); $M_{\mathrm{O}}$ was assumed for the current study. SKA101, SKB116, PM13013, PM13083, PM13161, AG9: Natural amphibolites and low-temperature granulites (unpublished), $X_{\mathrm{Fe}^{3+}}$ estimated at 0.10-0.25 from previous pseudosection modelling. SQA: Synthetic amphibolite composition of Patiño Douce \& Beard (1995) (glass analysis). The compositions at high and low $P$ are the same except for different assumed $M_{\mathrm{O}}$ values at high- $P$ (piston cylinder apparatus) and low- $P$ (internally heated pressure vessel); see text. $M_{\mathrm{H}_{2} \mathrm{O}}$ from analysis of starting material. In Fig. 5, $0.33<M_{\mathrm{O}}<0.82$, 3.50< $M_{\mathrm{H}_{2} \mathrm{O}}<6.50$. BL478: Sample 478 of Beard \& Lofgren (1991). See text for $M_{\mathrm{H}_{2} \mathrm{O}}, M_{\mathrm{O}}$ estimates. In Fig. 5, 0.52< $M_{\mathrm{O}}<1.30,3.50<M_{\mathrm{H}_{2} \mathrm{O}}<6.50$. WW94: natural amphibolite composition of Wolf \& Wyllie (1994). AGS11.1: natural amphibolite composition of Skjerlie \& Patiño Douce (1995). IAT: meta island arc tholeiite of Rushmer (1991). BL571: Sample 571 of Beard \& Lofgren (1991). 
Table 2:

\begin{tabular}{|c|c|c|c|c|c|c|c|c|c|c|}
\hline ב & Assemblage & $P$ (kbar) & $T\left({ }^{\circ} \mathrm{C}\right)$ & $x$ (aug) & $y(\mathrm{aug})$ & $f($ aug $)$ & $z$ (aug) & $j$ (aug) & $x_{\mathrm{Ca}}^{\mathrm{X}}(g)$ & $x^{\text {an }}(p l)$ \\
\hline $\mathrm{IZ} 100^{1}$ & cpx opx g pl ilm & 9 & 900 & 0.26 & 0.08 & 0.06 & 0.89 & 0.04 & 0.19 & 0.53 \\
\hline & & & & 0.34 & 0.06 & 0.07 & 0.81 & 0.05 & 0.20 & 0.56 \\
\hline & cpx opx g pl bi ilm q $\mathrm{H}_{2} \mathrm{O}$ & 11 & 880 & 0.25 & 0.10 & 0.05 & 0.80 & 0.05 & 0.20 & 0.50 \\
\hline & & & & 0.25 & 0.01 & 0.11 & 0.73 & 0.15 & 0.20 & 0.31 \\
\hline DR9734 & cpx g pl sp & 10 & 1000 & $\begin{array}{l}0.17 \\
0.14\end{array}$ & $\begin{array}{l}0.19 \\
0.09\end{array}$ & $\begin{array}{l}0.03 \\
0.06\end{array}$ & $\begin{array}{l}0.77 \\
0.81\end{array}$ & $\begin{array}{l}0.07 \\
0.06\end{array}$ & $\begin{array}{l}0.21 \\
0.18\end{array}$ & $\begin{array}{c}0.64 \\
0.57\end{array}$ \\
\hline
\end{tabular}

${ }_{1}^{1}$ Natural sample (Kunz et al., 2014). $P-T$ estimate from pseudosection forward modelling of intercalated metapelitic rocks using the ds55 models. ${ }^{2}$ Natural sample from De Paoli (2006). $P-T$ estimate from the author's pseudosection forward modelling using the ds55 models. Representative values of compositional variables given to nearest 0.05. ${ }^{3}$ Experimental run 1303 of Adam et al. (1992), with starting material DR9734.

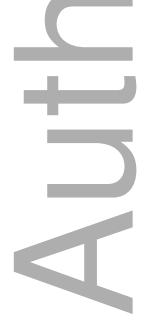

This article is protected by copyright. All rights reserved 
Table 3:

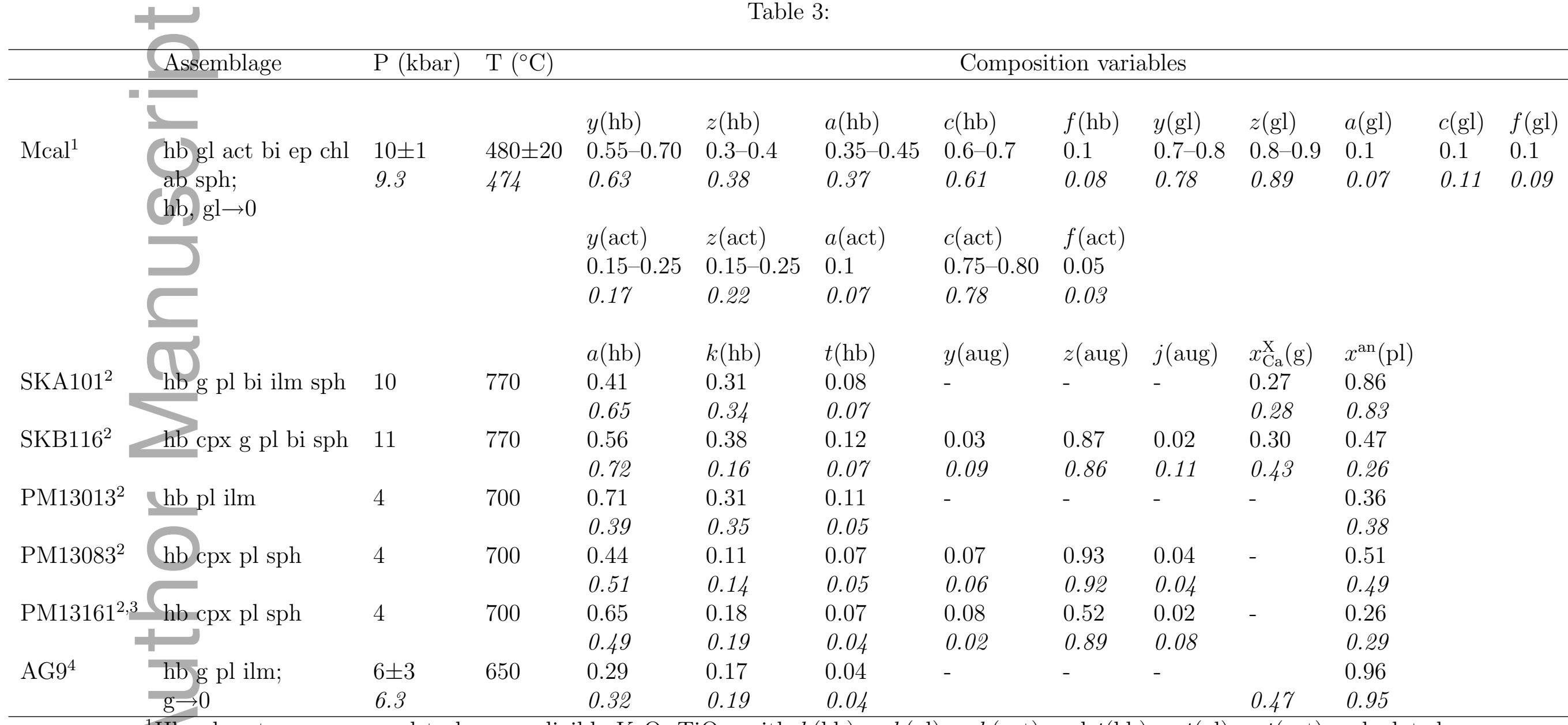

${ }^{1} \mathrm{Hb}, \mathrm{gl}$, act were assumed to have negligible $\mathrm{K}_{2} \mathrm{O}$, $\mathrm{TiO}_{2}$, with $k(\mathrm{hb})>k(\mathrm{gl}) \approx k($ act $)$ and $t(\mathrm{hb}) \approx t(\mathrm{gl})>t($ act $)$; calculated values are $0.02<k<0.04, t \leq 0.01$, with appropriate differences among the three phases. ${ }^{2} P-T$ estimated from pseudosection forward modelling with ds 55 models. ${ }^{3}$ Measured $j(\mathrm{aug})$ looks suspect. ${ }^{4}$ Garnet has $20 \%$ spessartine, unmodelled. 
(a) NCKFMASHTO $+\mathrm{q}\left(+\mathrm{H}_{2} \mathrm{O}\right.$, subsolidus)

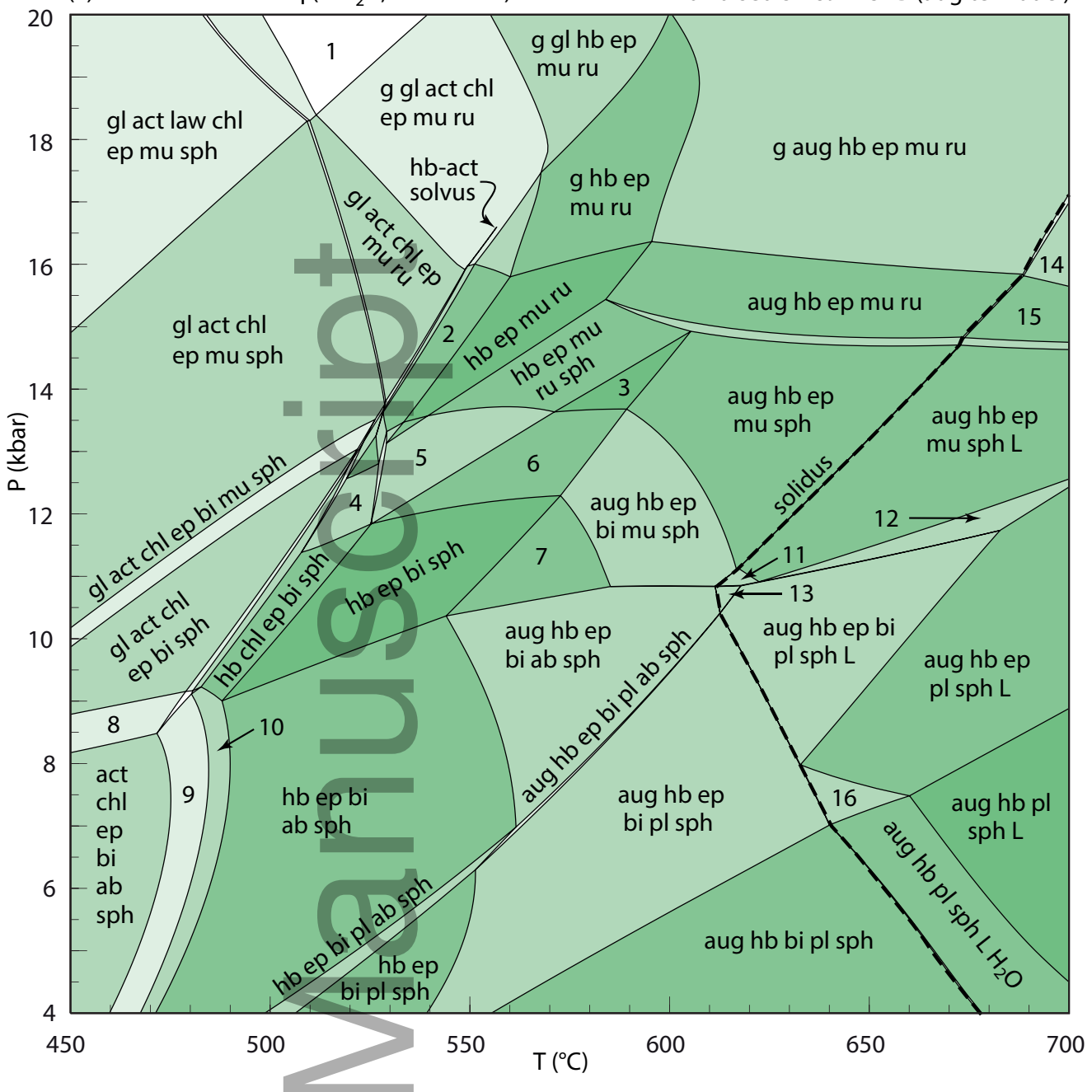

(c) NCKFMASHTO $+\mathrm{q}\left(+\mathrm{H}_{2} \mathrm{O}\right.$, subsolidus)

oxidised SM89 MORB (omphacite model)

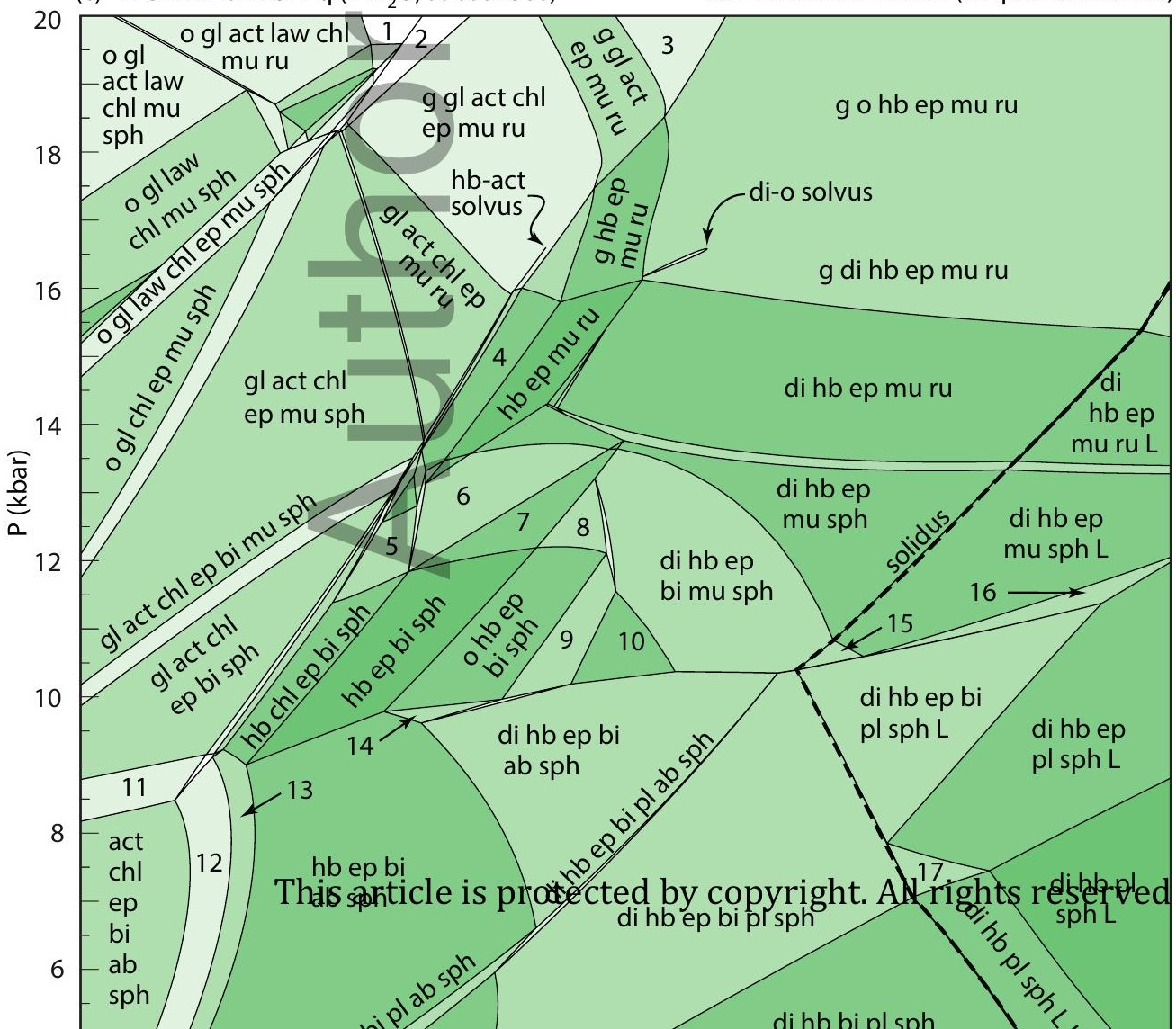

(b) contours of $j(\mathrm{cpx})=X_{\mathrm{Na}}^{\mathrm{M} 2}$

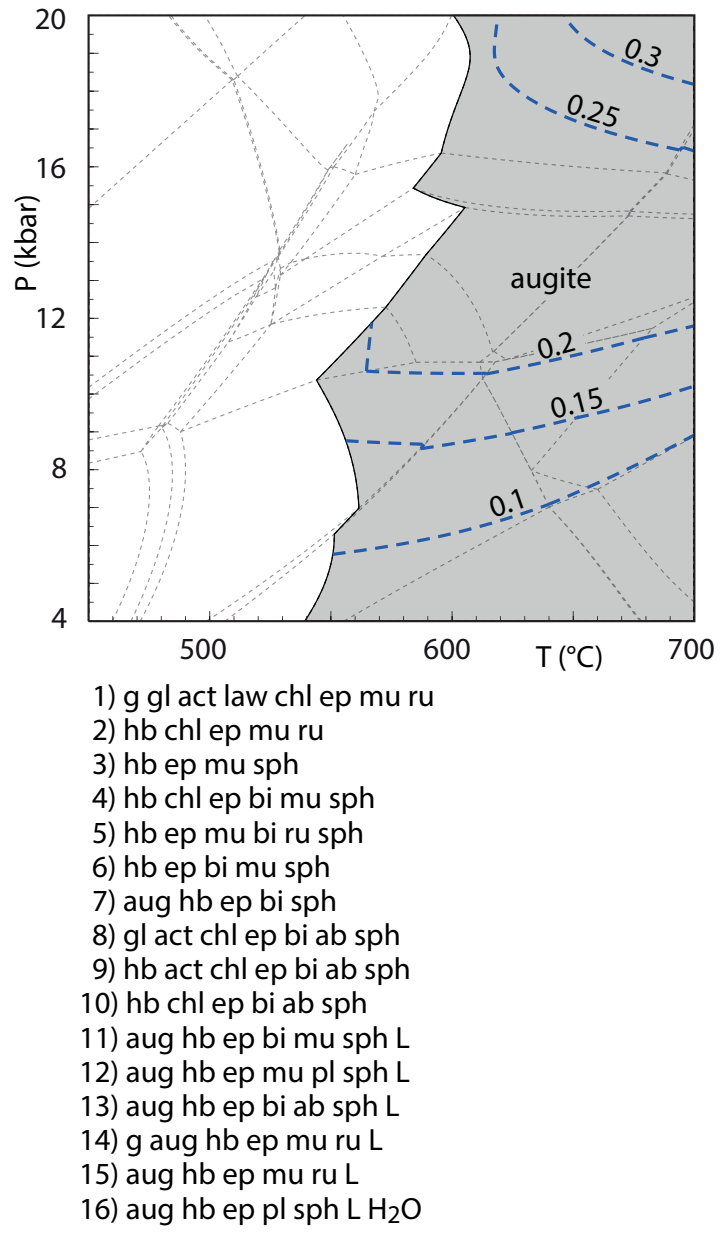

(d) contours of $j(\mathrm{cpx})=X_{\mathrm{Na}}^{\mathrm{M} 2}$

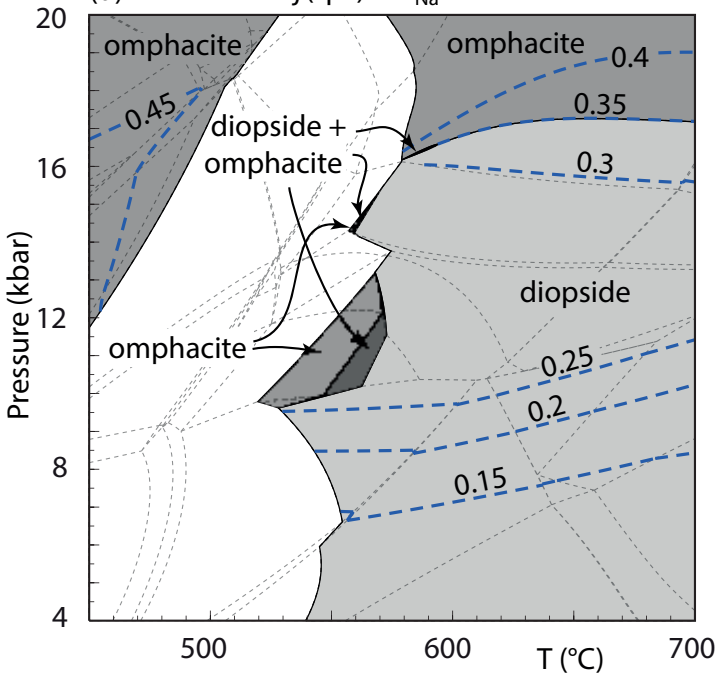

1) g o gl act law chl mu ru

2) g gl act law chl ep mu ru

3) g o gl act ep mu ru

4) hb chl ep mu ru

5) hb chl ep mu bi sph

6) hb ep mu bi ru sph

7) hb ep mu bi sph

8) o hb ep mu bi sph

9) o di hb ep bi sph

10) di hb ep bi sph

11) gl act chl ep bi ab sph

12) hb act chl ep bi ab sph

13) hb chl ep bi ab sph 

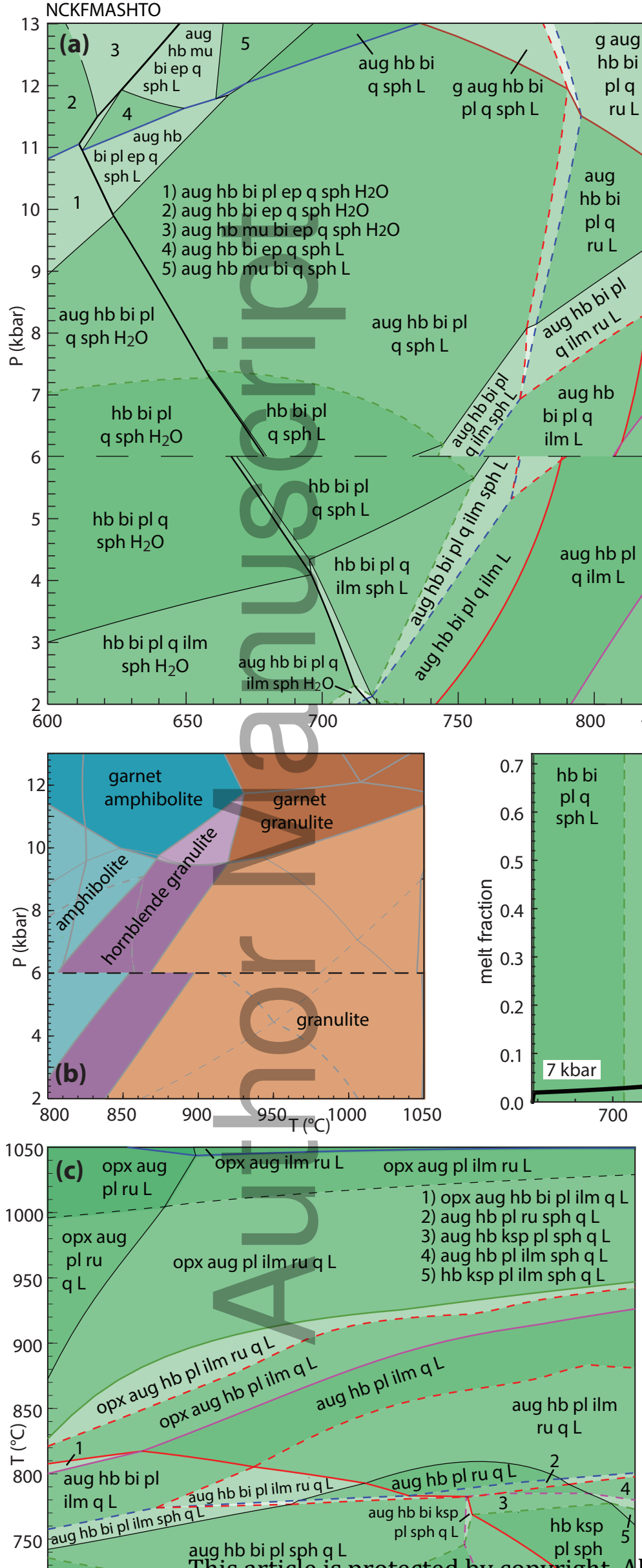

Patino-Douce \& Beard, 1995 SQA-composition

Patino-Douce \& Beard,

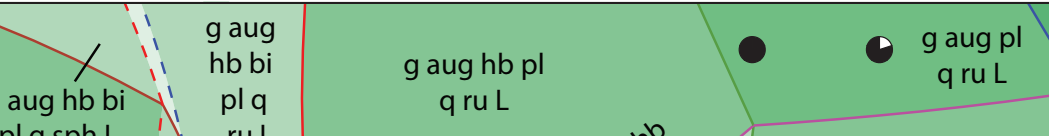

$\begin{array}{r}\text { gopx aug } \\ \text { q ru L } \\ \hline\end{array}$
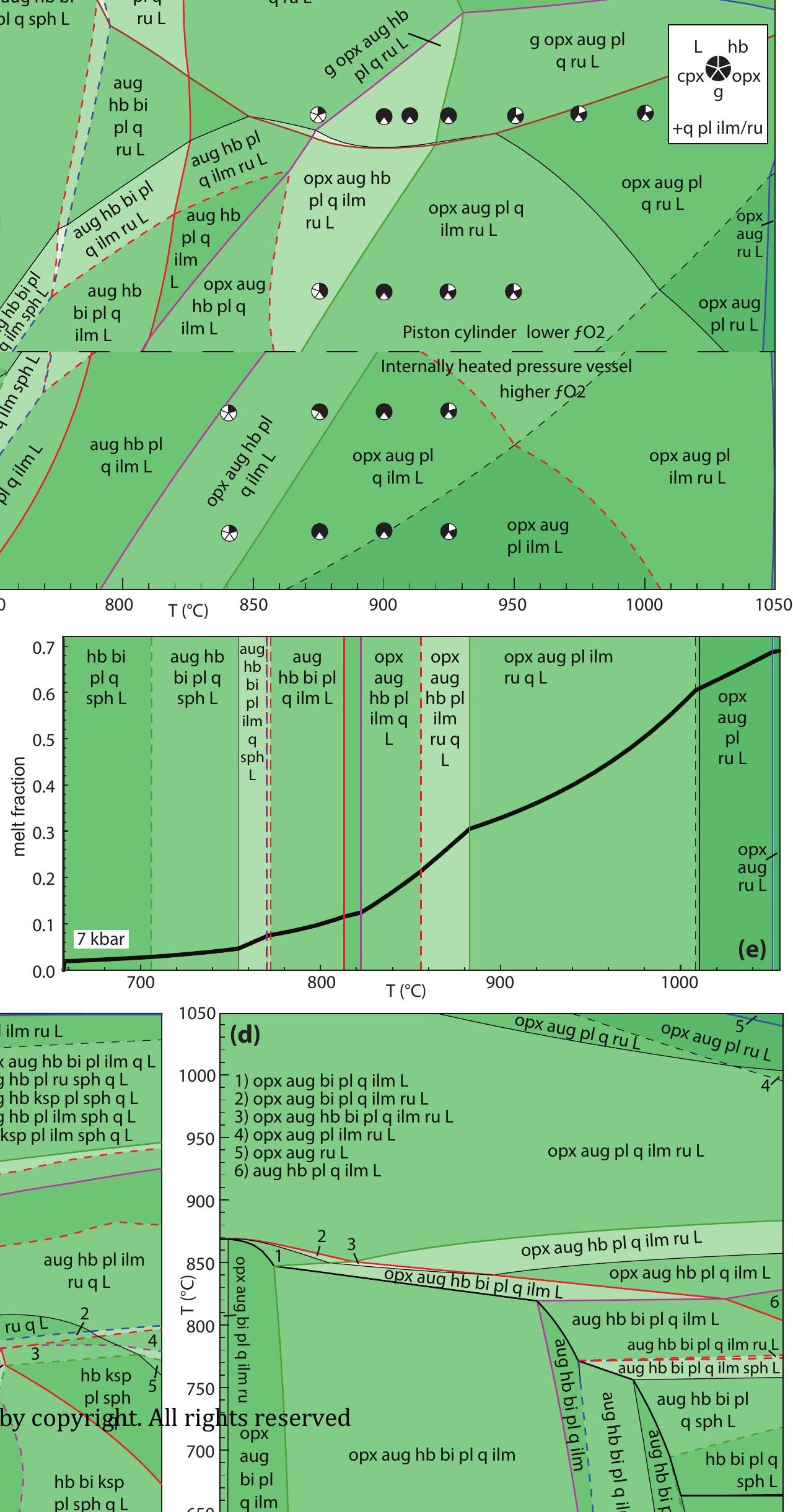


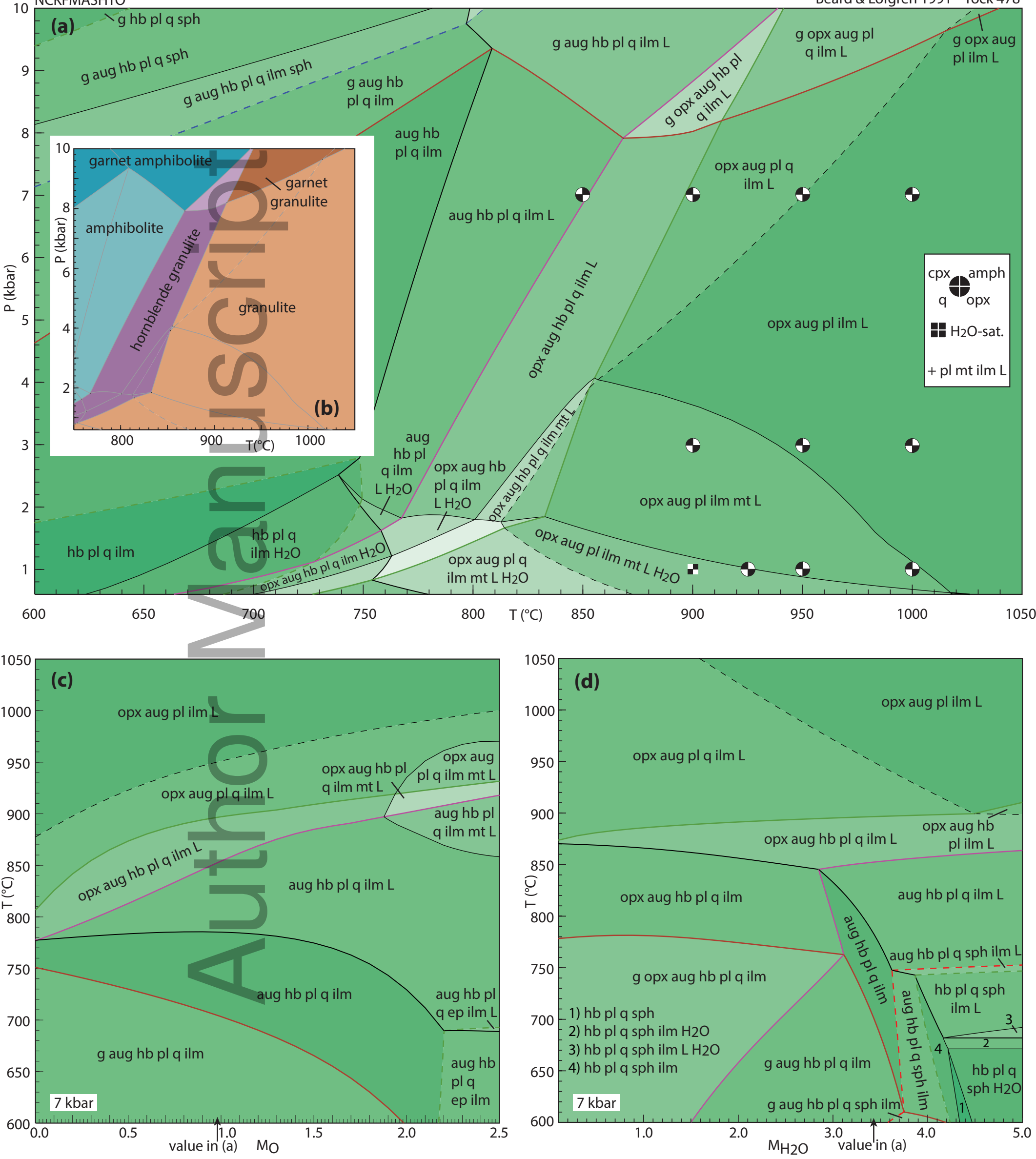

\section{This article is protected by copyright.All_rights reserved}


WW94a

$10 \mathrm{kbar}$

AGS11.1

$10 \mathrm{kbar}$

$\mathrm{IAT}^{\mathrm{b}}$

$7 \mathrm{kbar}$

$\mathrm{BL} 571^{\mathrm{a}, \mathrm{b}}$

$7 \mathrm{kbar}$

$S A^{c}$

$7 \mathrm{kbar}$

g aug pli q ilm $L-h b$

\section{opx aug pl ilm L -hb}

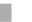

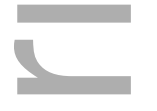

opx aug pl ilm mt L-hb

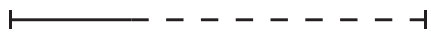

(

opx aug pl ilm ru q $L-h b$

$B L 478^{c}$

pl ilm mt $L \pm o p x \pm$ aug $\pm q-h b$ (experimental)

$7 \mathrm{kbar}$

opx aug pl ilm L $\pm q$-hb (calculated)

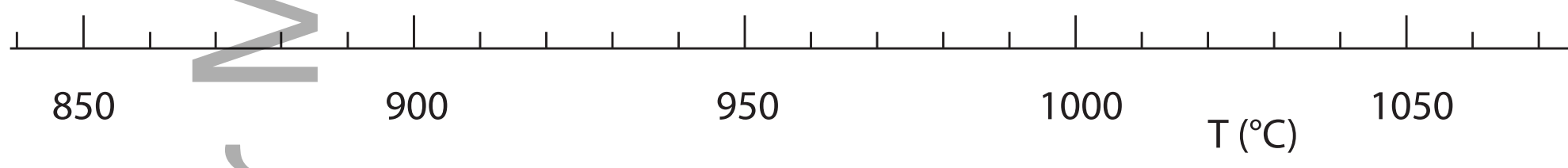

jmg_12211_f5.eps 


\section{University Library}

\section{- M M N E R VA A gateway to Melbourne's research publications}

Minerva Access is the Institutional Repository of The University of Melbourne

Author/s:

Green, ECR;White, RW;Diener, JFA;Powell, R;Holland, TJB;Palin, RM

Title:

Activity-composition relations for the calculation of partial melting equilibria in metabasic rocks

Date:

2016-12-01

Citation:

Green, E. C. R., White, R. W., Diener, J. F. A., Powell, R., Holland, T. J. B. \& Palin, R. M. (2016). Activity-composition relations for the calculation of partial melting equilibria in metabasic rocks. JOURNAL OF METAMORPHIC GEOLOGY, 34 (9), pp.845-869. https:// doi.org/10.1111/jmg. 12211 .

Persistent Link:

http://hdl.handle.net/11343/291668 